\title{
Contributions to the
}

Hydrology of the United States, 1955

GEOLOGICAL SURVEY WATER-SUPPLY PAPER 1360

This volume was printed as

separate chapters $A-I$

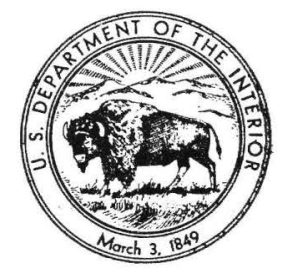


UNITED STATES DEPARTMENT OF THE JINTERIOR

FRED A. SEATON, Secretary

\section{GEOLOGICAL SURVEY}

Thomas B. Nolan, Director 


\section{CONTENTS}

[The letters in parentheses preceding the titles designate separately published chapters]

(A) Reservoirs in the United States, by Nathan O. Thomas and G. Earl Harbeck, Jr.

Ground water in northeastern Louisville, Ky., by M. I. Rorabaugh.

(C) Geology and occurrence of ground water in the Townsend Valley, Mont., by H. W. Lorenz and R. G. MeMurtrey

(D) Water resources of Bill Williams River valley near Alamo, Ariz., by H. N. Wolcott, H. E. Skibitzke, and L. C. Halpenny . . . . .

(E) Geology and ground-water resources of the Kaycee irrigation project, Johnson County, Wyo., by F. A. Kohout

(F) Salt water and its relation to fresh ground water in Harris County, Tex., by Allen G. Winslow, William W. Doyel, and Leonard A. Wood.

(G) Ground-water conditions in the Mendota-Huron area, Fresno and Kings Counties, Calif., by G. H. Davis and J. F. Poland ........-

(H) Geology and ground-water hydrology of the valleys of the Republican and Frenchman Rivers, Nebr., by Edward Bradley and Carlton R. Johnson

(I) Reconnaissance of the ground-water resources of the Elkhorn River basin above Pilger, Nebr., by Thomas G. Newport 



\section{Ground Water in}

Northeastern

Louisville, Kentucky

WITH REFERENCE TO INDUCED INFILTRATION

By M. I. RORABAUGH

CONTRIBUTIONS TO HYDROLOGY

GEOLOGICAL SURVEY WATER-SUPPLY PAPER 1360-B

Prepared in cooperation with the city of Louisville

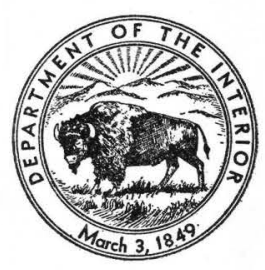




\section{UNITED STATES DEPARTMENT OF THE INTERIOR}

Fred A. Seaton, Secretary

\section{GEOLOGIGAL SURVEY}

Thomas B. Nolan, Director Washington 25, D. C. 


\section{CONTENTS}

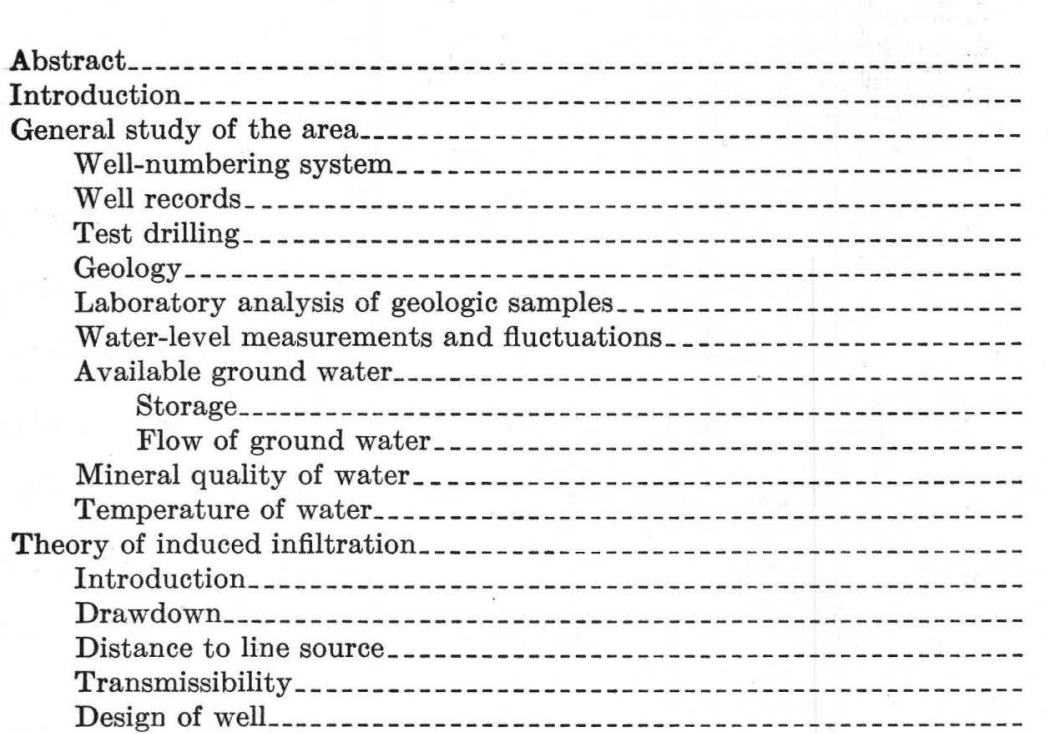

River infiltration .

Pumping-test data and procedure

Evidence of connection between aquifer and river.....................

Chemical analyses

Temperature

Drawdown corrections . .

Base flow

Effects of river fluctuations

Barometric effects

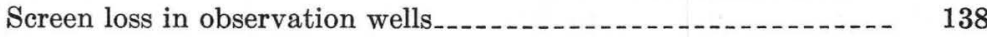

Adjustment for changes in pumping rate............... 139

Time-drawdown eurves_._._._._. 139

Profiles and distance to line source

Transmissibility

Storage coefficient.

Screen loss and effective radius of well _.

Estimated supplies available by induced infiltration from Ohio River.- 152

Accuracy of estimates_..._. 159

Silting of river bed._._.

Temperature

Odors and tastes.

Effect of development of infiltration supplies on existing wells_._._._._- 165

Summary and conclusions

Literature cited........ 167

Index . . 


\section{ILLUSTRATIONS}

[All plates are in pocket]

Plate 2. Map showing location of observation wells.

3. Map showing elevations of bedrock.

4. Sections of the Ohio River flood plain.

5. Map showing laboratory permeabilities.

6. Map showing elevations of piezometric surface, August 15, 1946.

7. Map showing temperatures of ground water.

8. Graphs of discharge and water level in pumped well.

9. Graphs of water level in observation wells $\mathrm{R} 1$ and $\mathrm{R} 2$ during pumping test.

10. Graphs of water level in observation wells R3, R4, and R5 and river level during pumping test.

11. Graphs of water level in observation wells D1, D2, and D3 during pumping test.

12. Graphs of water level in observation wells L1-L5, inclusive, during pumping test.

13. Graphs of water level in observation wells U1, U2, and U3 during pumping test.

14. Graphs of water level in observation wells R1T, R2T, and R3T during pumping test.

15. Graphs of water level in observation wells U1T, U2T, U3T, D1T, and L1T during pumping test.

16. Graphs of barometric pressure during pumping test.

17. Sections perpendicular to river showing temperature distribution during pumping test.

18. Sections parallel to river showing temperature distribution during pumping test.

FIgURE 4. Map of Louisville area showing physiographic units and area covered by this report

Page

5. Graphs of precipitation, river elevation, and ground-water elevation, 1937-47, in northeastern part of Louisville area_..

6. Map showing location of wells in pumping-test area _........

7. Sections of pumping-test area

8. Graph showing comparison of temperature of Ohio River and water from pumped well during test . . . . . . . . . . . . .......

9. Curves of sulfate content of Ohio River and well water during pumping test

10. Map showing sulfate content in water from observation wells_- $\quad 134$

11. Semilog time-drawdown curves, river line of wells_._._._._... 140

12. Semilog time-drawdown curves, downstream line of wells..... 140

13. Semilog time-drawdown curves, landward line of wells__._._._. 141

14. Semilog time-drawdown curves, upstream line of wells__.___.__ 141

15. Semilog time-drawdown curves, river line of wells screened at top of aquifer. . .

16. Semilog time-drawdown curves, downstream and landward wells screened at top of aquifer.

17. Semilog time-drawdown curves, upstream line of wells screened at top of aquifer 
Figure 18. Graph showing comparison of observed and theoretical drawdowns in an artesian aquifer affected by recharge from

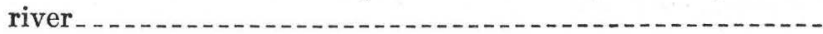

19. Graph showing comparison of observed and theoretical profiles in an artesian aquifer affected by recharge from river.-

20. Graphical determination of transmissibility after 1 day of pumping from an artesian aquifer affected by recharge from river. . . .

21. Graphical determination of transmissibility after 10 days of pumping from an artesian aquifer affected by recharge from river

22. Composite of semilog time-drawdown curves . . . . . . . .

23. Graphical solution of multiple-step drawdown test to determine aquifer constant $B$ and well-loss constant $C \ldots \ldots$

24. Graph showing estimated yield of wells of different radius at various distances from the Ohio River at section 300 feet downstream from city of Louisville river intake

25. Graph showing comparison of effects of river changes on water levels in wells in sections perpendicular to the river......

26. Graph showing estimated yield of a single unit in a line of large-radius units parallel to the river.........................

27. Estimated ground-water supplies available by induced infiltration if developed by units located along bank of Ohio River in area from Beargrass Creek to Harrods Creek...-

28. Thermographs of Ohio River water and water from collector at Bells Lane

\section{TABLES}

TABLE 1. Summary of records for wells in northeastern part of Louisville area.

2. Summary of records for test wells in northeastern part of Louisville area

3. Partial chemical analyses of water from test wells drilled in connection with the ground-water investigation northeast of Louisville.

4. Partial chemical analyses of water from production wells in northeastern part of Louisville area..............................

5. Chemical analyses of water from wells in northeastern part of Louisville area

6. Chemical analyses of water from pumped well and range in chemical content of Ohio River water during infiltration pumping test.

7. Data for observation wells used in pumping test.........

8. Summary of data from multiple-step drawdown test........... 
425.8

in. I

init

4.5

$\because \frac{x}{2}$

iv 5

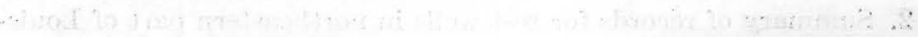
(3)

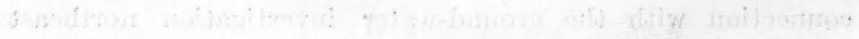

1:i 1 


\title{
CONTRIBUTIONS TO HYDROLOGY
}

\section{GROUND WATER IN NORTHEASTERN LOUISVILLE, KY., WITH REFERENGE TO INDUGED INFILTRATION}

\author{
By M. I. Rorabaugh
}

\section{ABSTRACT}

In cooperation with the city of Louisville, Ky., the U. S. Geological Survey made a detailed investigation during the period February 1945 to March 1947 of the ground-water resources of a 3-square-mile area along the Ohio River northeast of Louisville. Test drilling shows that the principal aquifer consists of about 80 feet of glacial-outwash sands and gravels lying in an old river channel which was cut into rocks of Ordovician, Silurian, and Devonian age.

The total ground-water storage in the area is estimated as 7 billion gallons. The ground-water levels are affected by changes in river elevation, by rainfall, and by the effects of pumping in the downtown part of Louisville 3 miles to the southwest. In the northeastern part of the area the flow of ground water, as defined by contour maps, is toward the river, and in the southwestern part of the area it is from the river toward the downtown area of overpumping.

Ground water in the area has an average temperature of $56^{\circ} \mathrm{F}$. The water, which is moderately hard, is suitable for domestic and industrial uses.

Analysis of a pumping test made during the investigation proves that infiltration supplies can be developed. Studies to determine the degree of connection between the river and aquifer were made on the basis of chemical analyses, sections showing temperature distribution in the aquifer during the pumping test, shapes of water-level profiles in the test area, and shapes of time-drawdown curves for a number of observation wells. Quantitative studies to evaluate the hydrologic constants of the aquifer were made by both graphical and mathematical methods. The transmissibility was determined as $121,000 \mathrm{gpd} / \mathrm{ft}$ in the test area; the distance to the line source, 400 feet; and the coefficient of storage, 0.0003. A comparison of river-level fluctuations and water-level fluctuations in observation wells shows that conditions along the 6.4-mile reach of river are not greatly different from those at the site of the pumping test.

It is estimated that under adverse temperature and river-stage conditions infiltration supplies could be developed to the extent of 280 million gpd in the entire 6.4-mile reach investigated; at average river-water temperature $\left(59^{\circ} \mathrm{F}\right)$ about 400 million gpd could be developed. Diagrams were drawn showing the estimated yield of wells of different radii, at various distances from the river, and at various spacings. In making the computations allowance was made for screen losses, dewatering of the aquifer, partial penetration of wells, location of wells, eccentricity of large wells, and interference among wells. 
Developed infiltration supplies will have a seasonal temperature cycle whose range will be considerably less than the approximately $53^{\circ}\left(32^{\circ}-85^{\circ} \mathrm{F}\right)$ range of river water. Yields will be least during periods of low temperature and greatest during periods of high temperature.

\section{INTRODUCTION}

One of the most important factors influencing the industrial development of the Louisville area, Kentucky, has been the large ground-water supplies in the glacial-outwash deposits underlying the Ohio River flood plain. Many industries have been located in the area because of the availability of this ground water and because the temperature and quality of the water are ideal for many processes. During the Second World War, expansion of existing plants and construction of new plants (particularly in the chemical, alcohol, and rubber industries) resulted in overdevelopment of this natural resource in heavily industrialized areas. A detailed investigation ${ }^{1}$ in 1943 and 1944 indicated that additional supplies might be obtained southwest or northeast of the city. The Rubber Reserve Company, the Federal agency responsible for synthetic-rubber production during the Second World War, financed an investigation of the 50 square-mile area southwest of the city. ${ }^{2}$

In connection with the ground-water investigations of the Louisville area, the U. S. Geological Survey, in cooperation with the city of Louisville, began in February 1945 an investigation of the groundwater resources of the area along the Ohio River, northeast of the city of Louisville. The need for such an investigation to determine the quantity and quality of ground water available in the area is due to the fact that water of the Ohio River from which the municipal water supply at Louisville is taken, has become more and more difficult to treat because of the industrial waste discharged into the river at points upstream. Such changes in the quality of the water make it important to investigate other sources of water that would be available if the river water became unsatisfactory for use. This problem is present in other areas along the Ohio River, and therefore investigations of ground water in the Louisville area are valuable in providing a basis for work in other localities where ground water is needed for municipal or industrial use.

The investigation covers the area (fig. 4) of glacial-outwash deposits along the Ohio River extending from Beargrass Creek to Harrods Creek, a strip approximately 6 miles long and averaging $1 / 2$ mile wide.

1 Guyton, W. F., Stuart, W. T., and Maxey, G. B., 1944, Progress report on the ground-water resources of the Louisville area, Kentucky. Prepared by the Geological Survey, in cooperation with the Geological Division, Kentucky State Department of Mines and Minerals, and the city of Louisville, March. (Manuscript report in files of U. S. Geological Survey.)

2 Rorabaugh, M. I., 1946, Ground-water resources of the southwestern part of the Louisville, area, Kentucky. Prepared by the Geological Survey, in cooperation with the Rubber Reserve Company, the city of Louisville, and Jefferson County, December. (Manuscript report in files of U. S. Geological Survey.) 


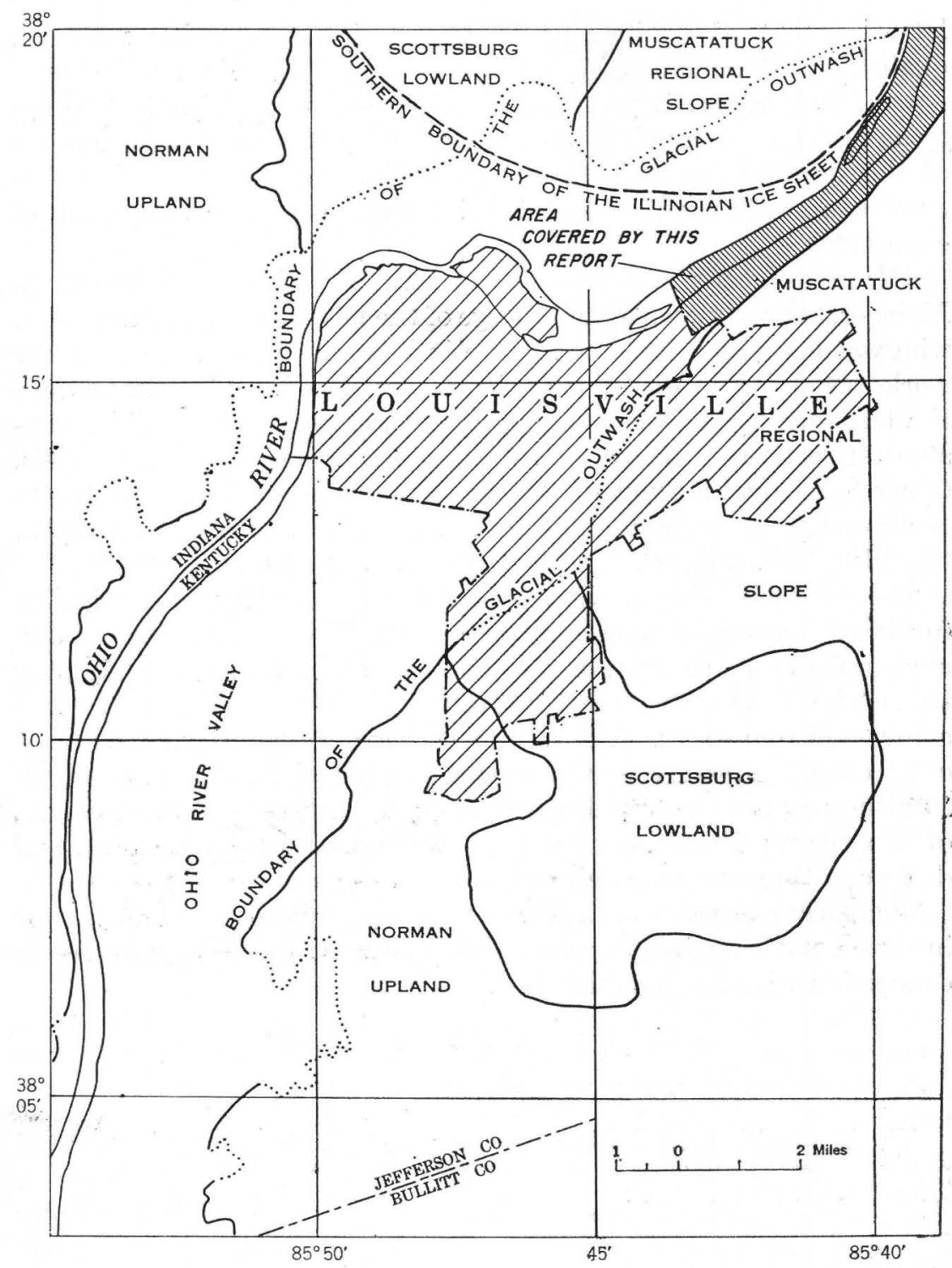

FIGURE 4.-Map of Loulsville area showing physiographic units and area covered by this report

This report presents in detail the data collected during this investigation, together with an analysis of the data. It was released to the open file in 1948 and has not been revised to reflect the results of later studies of induced infiltration in the Louisville area or elsewhere. It constitutes, however, the principal basic information released by the Geological Survey to date on the subject of induced infiltration. Information is given on elevation of bedrock, elevation of water table, 
lateral extent of aquifer, permeability of water-bearing material, quality and temperature of ground water, and direction and rates of flow of ground water. Analysis is given for a pumping test to determine the extent of river infiltration, and estimates have been made of the supplies available from infiltration. Also included is a discussion of the theory of induced infiltration, with development of equations.

The investigation was under the general direction of the late O. E. Meinzer, formerly geologist in charge of the Division of Ground Water, who was succeeded by A. N. Sayre in December 1946. Locally the work was under the direction of the writer. R. W. Kellogg supervised the test drilling and field work for the pumping test and did a substantial portion of the detailed work in connection with the analysis. Other Geological Survey employees in Louisville who contributed to the investigation were E. A. Bell, F. S. Dowell, F. V. Hunter, Mary L. Grunder, Mrs. Edith S. Nichols, and D. M. Phelps.

The Louisville Water Co., an agency of the city of Louisville, furnished records of temperature and quality of river water and analyses of seven samples of ground water taken during the pumping test. The State Department of Health of Kentucky made bacterial analyses of well water. The U. S. Weather Bureau furnished a record of barometric pressure, and records of precipitation. Data have been furnished by the Corps of Engineers, U. S. Army; the State Geologist of Kentucky; Commissioners of Sewerage of Louisville; the well drillers in the area; and well owners.

Thanks are also due C. E. Jacob, formerly senior hydraulic engineer in the U. S. Geological Survey, Wasbington, D. C., for suggestions in connection with the pumping test.

\section{GENERAL STUDY OF AREA}

\section{WELL-NUMBERING SYSTEM}

The Louisville area lies between long $85^{\circ}$ and $86^{\circ} \mathrm{w}$. and lat $38^{\circ}$ and $39^{\circ} \mathrm{N}$. The area has been subdivided into 1-minute quadrangles. The wells in each of these quadrangles are numbered in the order inventoried. A well is designated by a composite of three numbers: the first indicates the minutes of longitude; the second, the minutes of latitude; and the third, the number of the well in that quadrangle. Thus, well $41-17-3$ is the third well inventoried in the 1-minute quadrangle west of long $85^{\circ} 41^{\prime} \mathrm{W}$. and north of lat $38^{\circ} 17^{\prime} \mathrm{N}$.

\section{WELL RECORDS}

Records of wells in this area were collected in connection with the general investigation of the Louisville area. Information on these 
wells is summarized in table 1 . Well locations are shown on plates 2 and 3. It should be noted that relatively few production wells have been drilled in the area.

\section{TEST DRILIING}

In order to obtain information concerning the geologic and hydrologic conditions in the area, 30 test wells were drilled under contract. Location of these wells is shown in plate 2. This illustration also shows the location of existing wells at which water-level records were obtained. The test-well sites were chosen to fit into the pattern of existing wells at which water levels could be measured, so that analysis of direction and quantity of flow could be made. A line of wells was drilled at about half-mile intervals along the river's edge to determine the available head and type of material in connection with possible development of river-infiltration supplies. Wells were located in lines perpendicular to the river, where practical, in order to study the relationship of river fluctuations to water-level fluctuations. Fifteen of the test wells were located in the form of a cross at the pumping-test location, immediately downstream from the Louisville Water Co. pumping station. Three of these wells were in the river bed.

The test wells were drilled by the standard cable-tool method, cased with 4 -inch standard steel casing, and screened at the bottom with 2 feet of well screen of either No. 10 (0.010 inch) or No. 30 (0.030 inch) slot size, depending on the texture of the sand and gravel. The three wells in the river were cased with $6 \frac{112}{2}$-inch steel casing which was slotted near the bottom. The wells were developed until clear water was obtained. Data for the test wells appear in table 2.

Samples of the material encountered were taken every 5 feet, or more frequently if the type of material changed. Drilling was carried a few feet into bedrock in most of the wells. Geologic samples from these wells are stored at the U. S. Geological Survey office in Louisville and are available for inspection.

\section{GEOLOGY}

This report covers an area of unconsolidated glacial-outwash and river deposits of Pleistocene and Recent age lying in the Ohio River valley. The valley was cut into limestones, shales, and dolomites of Ordovician, Silurian, and Devonian age. These formations dip gently toward the west. In the area under study the valley, about $1 \frac{1}{4}$ miles in width, is U-shaped, having a broad, relatively flat bottom and steep valley walls. 
TABLE 1.-Summary of records for wells in northeastern part of Louisville area

\begin{tabular}{|c|c|c|c|c|c|c|c|c|c|c|}
\hline \multirow{2}{*}{$\begin{array}{l}\text { Well } \\
\text { No. }\end{array}$} & \multirow{2}{*}{ Location 1} & \multirow{2}{*}{ Property owner } & \multirow{2}{*}{ Driller } & \multirow{2}{*}{$\begin{array}{l}\text { Date } \\
\text { drilled }\end{array}$} & \multirow{2}{*}{$\begin{array}{l}\text { Depth } \\
\text { (feet) }\end{array}$} & \multirow{2}{*}{$\begin{array}{c}\text { Diameter } \\
\text { (inches) }\end{array}$} & \multicolumn{2}{|c|}{ Screen } & \multicolumn{2}{|c|}{$\begin{array}{l}\text { Elevation (feet } \\
\text { above sea level) }\end{array}$} \\
\hline & & & & & & & $\begin{array}{l}\text { Length } \\
\text { (feet) }\end{array}$ & $\begin{array}{c}\text { Slot } \\
\text { (inches) }\end{array}$ & $\begin{array}{l}\text { Land } \\
\text { surface }\end{array}$ & Bedrock \\
\hline $\begin{array}{l}38-19-1 \\
38-90-2\end{array}$ & Harrods Creek & & & & 48 & 4 & & & 429 & \\
\hline $\begin{array}{l}38-20-2 \\
40-17-1\end{array}$ & & W. W. Liter & & & 45 & 6 & NTn & & & \\
\hline $\begin{array}{l}40-17-1 \\
40-17-2\end{array}$ & $\begin{array}{l}\text { River Road and ndian Hills Trail. } \\
\text { River Road and Blankenbaker Lane. }\end{array}$ & $\begin{array}{l}\text { Union Park } \\
\text { Louisville Trust Co } 8 . . .\end{array}$ & U. s. Geological survey_ & $2-8-44$ & $\begin{array}{l}36.4 \\
28.4\end{array}$ & 30 & $\begin{array}{r}\text { None } \\
3\end{array}$ & 0.01 & $\begin{array}{l}443.3 \\
436.6\end{array}$ & \\
\hline $41-16-1$ & $\begin{array}{l}1,000 \mathrm{ft} \text { south of entrance of Wagners } \\
\text { Beach and River Road. }\end{array}$ & Attilla Cox & . do do & $2-4-44$ & $\begin{array}{l}28.4 \\
29.9\end{array}$ & $\begin{array}{l}11 / 4 \\
11 / 4\end{array}$ & 3 & $\begin{array}{r}0.01 \\
.01\end{array}$ & $\begin{array}{l}\begin{array}{l}450.0 \\
434.5\end{array} \\
434\end{array}$ & \\
\hline 41-16-5 & Pastime Boat Club, River Road.... & Pastime Boat Club .... & Diehl Pump and Sup- & 1946. & 98.7 & 6 & 10 & .02 & 434.8 & 336. \\
\hline 41-17-1 & $250 \mathrm{ft}$ south of River Road, $250 \mathrm{ft}$ & Sam J. Hamrick . & & & 40.5 & 36 & None & & 443.9 & \\
\hline $42-15-1$ & $\begin{array}{l}750 \mathrm{ft} \text { northwest of Mellwood Ave. } \\
\text { and Delmont St. }\end{array}$ & Fischer Packing Go..... & Layne-Central Co....... & 1928 & 91 & 30 & 20 & $\left({ }^{2}\right)$ & 427 & 336 \\
\hline $\begin{array}{l}42-15-2 \\
42-16-1\end{array}$ & River Road, Beargrass Creek & Louisville Gas and Elec- & Bates . & $\begin{array}{l}1938 \\
1923\end{array}$ & - $\begin{array}{l}102 \\
100\end{array}$ & $\begin{array}{l}30 \\
18\end{array}$ & $\begin{array}{l}20 \\
20\end{array}$ & $\stackrel{(2)}{.02}$ & $\begin{array}{l}427 \\
438\end{array}$ & $\begin{array}{l}325 \\
338\end{array}$ \\
\hline $\begin{array}{l}42-16-2 \\
42-16-3\end{array}$ & River Road, Beargrass Plant of & $\begin{array}{l}\text { tric Co. } \\
\text { do }\end{array}$ & $\begin{array}{l}\text { Andriot-Davidson Co...- } \\
\text { U. S. Geological Survey. }\end{array}$ & $\begin{array}{r}1939 \\
1-31-44\end{array}$ & $\begin{array}{l}96 \\
27\end{array}$ & 18 & $\begin{array}{r}30 \\
3\end{array}$ & $\begin{array}{l}.03 \\
.01\end{array}$ & $\begin{array}{l}432 \\
426\end{array}$ & 336 \\
\hline 42-16-4 & $\begin{array}{l}\text { River Road, } 1 / 2 \text { mile east of Louis- } \\
\text { ville Gas and Electric Co }\end{array}$ & ....... do & ......do_- & $1-31-44$ & 25.1 & $1 \frac{1}{4}$ & 3 & .01 & 428 & \\
\hline $42-16-5$ & $\begin{array}{l}1,000 \mathrm{ft} \text { south of River Road and east } \\
\text { of Shiloh A ve. }\end{array}$ & Henry Chambers....... & ...... do & $1-27-44$ & 26.1 & $11 / 4$ & 3 & .01 & 430 & \\
\hline 42-17-1 & $\begin{array}{l}\text { East of Jeffersonville, Ind. in Arctic } \\
\text { Spring Summer Camp area. }\end{array}$ & $\begin{array}{l}\text { Public Service Co, of } \\
\text { Ind. }\end{array}$ & & 1943 & 76 & & & & 446. 7 & 371 \\
\hline $\begin{array}{l}42-17-2 \\
42-17-3\end{array}$ & do & do & & $\begin{array}{l}1943 \\
1943\end{array}$ & 59 & $\begin{array}{l}11 / 2 \\
11 / 4\end{array}$ & & & 445.7 & $\begin{array}{l}387 \\
416\end{array}$ \\
\hline $42-17-4$ & do & (n) do & ........ & 1943 & & & & & & 428 \\
\hline $42-17-5$ & do & $\ldots$ do $=\ldots$. & & 1943 & 67 & & & & 445.3 & 378 \\
\hline $\begin{array}{l}43-15-1 \\
43-15-8\end{array}$ & Point Sewerage Pumping Station.... & City of Louisville & ............... & $11-18-37$ & 58 & 4 & None & & $446+$ & \\
\hline $\begin{array}{l}43-15-8 \\
43-16-1\end{array}$ & $\begin{array}{l}1726 \text { Mellwood A ve } \\
\text { Municipal Boat Harbor }\end{array}$ & General Distillers, Inc -- & Ù s Geological survey & Dec. 1936 & 80.5 & 12 & 15 & 01 & 446. 7 & 366. \\
\hline $43-16-2$ & Crestview and Charleston A venues, & Public Service Có of & 0. s. Georogical survey. & $\begin{array}{l}1-25-44 \\
2-23-43\end{array}$ & $\begin{array}{l}27.8 \\
44.5\end{array}$ & $\begin{array}{l}11 / 4 \\
6\end{array}$ & & .01 & 462 & 418 \\
\hline $43-16-3$ & $\begin{array}{l}\text { One block west of Main and Market } \\
\text { Sts., Jeffersonville, Ind. }\end{array}$ & $\begin{array}{l}\text { Ind. } \\
\text { Corps of Engineers, } \\
\text { U. S. Army. }\end{array}$ & $\begin{array}{l}\text { Corps of Engineers, } \\
\text { U. S. Army. }\end{array}$ & & 32.0 & & & & 445 & 413 \\
\hline $43-16-4$ & $\begin{array}{l}\text { Jefferson and Market Sts., Jefferson- } \\
\text { ville, Ind. }\end{array}$ & do $\mathrm{d}_{\ldots}$ & & & 33 & & & & 444 & 411 \\
\hline 43-16-5 & Division and Market Sts., Jefferson- & do & do & & 44 & & & & 446 & 402 \\
\hline $43-16-6$ & Jeffersonville Boat and Machine Co.. & $\begin{array}{l}\text { Jeffersonville Boat and } \\
\text { Machine Co. }\end{array}$ & $\begin{array}{l}\text { Diehl Pump and Sup- } \\
\text { ply Co. }\end{array}$ & Aug. 1942 & 57 & 12 & & & 440 & 384 \\
\hline
\end{tabular}


TABLE 2.-Summary of records for test wells in northeastern part of Louisville area

[Driller: R, Ranney Method Water Supplies, Inc.; U, U. S. Geological Survey; V, C. B. Venhoff]

\begin{tabular}{|c|c|c|c|c|c|c|c|c|c|c|c|c|c|c|}
\hline \multirow[b]{2}{*}{$\begin{array}{l}\text { Well } \\
\text { No. }\end{array}$} & \multirow[b]{2}{*}{$\begin{array}{l}\text { Pump- } \\
\text { ing test } \\
\text { No. }\end{array}$} & \multirow[b]{2}{*}{ Location } & \multirow[b]{2}{*}{ Property owner } & \multirow[b]{2}{*}{ Driller } & \multirow[b]{2}{*}{$\begin{array}{l}\text { Date } \\
\text { drilled }\end{array}$} & \multirow[b]{2}{*}{$\begin{array}{l}\text { Depth } \\
\text { (feet) }\end{array}$} & \multirow[b]{2}{*}{$\begin{array}{l}\text { Diam- } \\
\text { eter } \\
\text { (inches) }\end{array}$} & \multicolumn{2}{|c|}{ Screen } & \multicolumn{5}{|c|}{ Elevation (feet above mean sea level) of- } \\
\hline & & & & & & & & $\underset{\text { (feet) }}{\text { Length }}$ & $\begin{array}{c}\text { Slot } \\
\text { (inches) }\end{array}$ & $\begin{array}{l}\text { Top of } \\
\text { casing }\end{array}$ & $\begin{array}{c}\text { Land } \\
\text { surface }\end{array}$ & $\begin{array}{c}\text { Bottom } \\
\text { of } \\
\text { sereen }\end{array} \mid$ & $\begin{array}{l}\text { Bed- } \\
\text { rock }\end{array}$ & $\begin{array}{l}\text { Water } \\
\text { level on } \\
\text { comple- } \\
\text { tion } \\
\text { of well }\end{array}$ \\
\hline $38-19-2$ & & $\begin{array}{l}\text { River Road, northeast of bridge } \\
\text { over Goose Creek. }\end{array}$ & Jefferson County & V & $8-3-46$ & 110.0 & 4 & 2 & 0.030 & 440.74 & 438.5 & 342.3 & 334.5 & 419.34 \\
\hline $39-18-1$ & & $\begin{array}{l}\text { River Road opposite River } \\
\text { Valley Club. }\end{array}$ & do do & $\mathrm{V}$ & $7-31-46$ & 130.0 & 4 & 2 & .030 & 458. 56 & 455.9 & 345.7 & 335.9 & 419. 59 \\
\hline 40-17-3 & & $\begin{array}{l}\text { River Road and Indian Hills } \\
\text { Trail. }\end{array}$ & ......do do.... & V & $5-29-46$ & 103.0 & 4 & 2 & .030 & 436. 29 & 433.5 & 334.0 & 334.0 & 1419.90 \\
\hline $40-17-4$ & & $\begin{array}{c}\text { Indian Hills Trail, } 1,500 \mathrm{ft} \\
\text { southeast of River Road. }\end{array}$ & ......do do & $\mathbf{V}$ & $6-4-46$ & 74.4 & 4 & 2 & .030 & 437. 66 & 435.2 & 366.8 & 363.2 & 419. 70 \\
\hline $40-17-5$ & & $\begin{array}{l}\text { River Road, } 300 \text { ft northeast of } \\
\text { Blankenbaker Lane. }\end{array}$ & Lyndon Everbach. - . & $\mathrm{V}$ & $6-6-46$ & 105.6 & 4 & 2 & .030 & 441.94 & 438.9 & 340.6 & 336.3 & 419. 72 \\
\hline $41-16-2$ & L5 & $\begin{array}{l}\text { Zorn Ave., } 1,000 \mathrm{ft} \text { southeast of } \\
\text { River Road. }\end{array}$ & City of Louisville... & $\mathrm{V}$ & $4-18-46$ & 94.0 & 4 & 2 & .010 & 432.64 & 428.5 & 344.5 & 336.0 & 419.99 \\
\hline $\begin{array}{l}41-16-3 \\
41-16-4\end{array}$ & L4 & $\begin{array}{l}\text { River Road and Zorn Ave } \\
\text { River Road at entrance to } \\
\text { Wagners Beach. }\end{array}$ & $\begin{array}{l}\text { Columbia Fidelity } \\
\text { Trust Co. }\end{array}$ & $\begin{array}{l}\mathrm{V} \\
\mathrm{V}\end{array}$ & $\begin{array}{l}4-23-46 \\
5-21-46\end{array}$ & $\begin{array}{l}104.2 \\
104.0\end{array}$ & $\begin{array}{l}4 \\
4\end{array}$ & $\begin{array}{l}2 \\
2\end{array}$ & $\begin{array}{c}2.010 \\
1^{\prime}-.010 \\
1^{\prime}-.020\end{array}$ & $\begin{array}{l}436.70 \\
441.28\end{array}$ & $\begin{array}{l}435.8 \\
438.0\end{array}$ & $\begin{array}{l}335.8 \\
346.7\end{array}$ & $\begin{array}{l}335.8 \\
337.0\end{array}$ & $\begin{array}{r}420.86 \\
1420.19\end{array}$ \\
\hline $41-17-2$ & & Wagners Beach & . do do & V & $5-17-46$ & 95.6 & 4 & 2 & $\begin{array}{r}7.020 \\
2.010\end{array}$ & 429. 24 & 427.5 & 344.7 & 335.9 & 419.74 \\
\hline $41-17-3$ & & $\begin{array}{l}25 \mathrm{ft} \text { from river edge, } 1,750 \mathrm{ft} \\
\text { upstream from Wagners } \\
\text { Beach. }\end{array}$ & do do.............. & V & $5-23-46$ & 103.0 & 4 & 2 & $\begin{array}{l}1^{\prime}-.010 \\
1^{\prime}-.020\end{array}$ & 439.01 & 435.7 & 336.9 & 335.7 & 420.61 \\
\hline $\begin{array}{r}42-16-15 \\
42-16-16\end{array}$ & 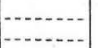 & $1,400 \mathrm{ft}$ northeast of Louisville & $\begin{array}{l}\text { City of Louisville } \\
\text { Louisville Gas and }\end{array}$ & $\begin{array}{l}\mathrm{V} \\
\mathrm{V}\end{array}$ & $\begin{array}{l}4-30-46 \\
5-4-46\end{array}$ & $\begin{array}{l}102.4 \\
102.2\end{array}$ & $\begin{array}{l}4 \\
4\end{array}$ & $\underset{2}{2}$ & $\begin{array}{l}2.010 \\
2.010\end{array}$ & $\begin{array}{l}437.24 \\
432.78\end{array}$ & $\begin{array}{l}435.1 \\
429.2\end{array}$ & $\begin{array}{l}336.8 \\
337.8\end{array}$ & $\begin{array}{l}336.4 \\
334.5\end{array}$ & $\begin{array}{l}420.04 \\
419.01\end{array}$ \\
\hline & Da & $\begin{array}{l}\text { Gas and Electric Co. Bear- } \\
\text { grass Plant, } 600 \mathrm{ft} \text { northwest } \\
\text { of River Road. }\end{array}$ & Electric Co. & & & & & & 2.010 & 432. 78 & 429.2 & 337.8 & 334.5 & 419.01 \\
\hline $42-16-17$ & D4 & $\begin{array}{l}1,500 \mathrm{ft} \text { northeast of Louisville } \\
\text { Gas and Electric Co. Bear- } \\
\text { grass Plant, } 1,600 \mathrm{ft} \text { northwest } \\
\text { of River Road, } 20 \mathrm{ft} \text { from river } \\
\text { edge. }\end{array}$ & .......do & V & $5-9-46$ & 89.0 & 4 & 2 & 2.010 & 426.22 & 422.7 & 339.8 & 337.7 & 419. 53 \\
\hline 42-16-18 & -.......... & $\begin{array}{l}800 \mathrm{ft} \text { southeast of River Road, } \\
\text { northeast of Freys Lane. }\end{array}$ & A. Stoecker. & $\mathbf{V}$ & $6-8-46$ & 86.0 & 4 & 2 & .010 & 435. 38 & 434.6 & 358.6 & 349.6 & 419. 60 \\
\hline 42-16-19 & U3 & (3) & City of Louisville...... & V & $6-12-46$ & 88.3 & 4 & 3 & .030 & 428.97 & 424. 2 & 348.2 & 336.2 & 419.80 \\
\hline
\end{tabular}




\begin{tabular}{|c|c|c|c|c|c|c|c|c|c|c|c|c|c|c|}
\hline \multirow[b]{2}{*}{$\begin{array}{l}\text { Well } \\
\text { No. }\end{array}$} & \multirow[b]{2}{*}{$\begin{array}{l}\text { Pump- } \\
\text { ing test } \\
\text { No. }\end{array}$} & \multirow[b]{2}{*}{ Location } & \multirow[b]{2}{*}{ Property owner } & \multirow[b]{2}{*}{ Driller } & \multirow[b]{2}{*}{$\begin{array}{c}\text { Date } \\
\text { drilled }\end{array}$} & \multirow[b]{2}{*}{$\begin{array}{l}\text { Depth } \\
\text { (feet) }\end{array}$} & \multirow[b]{2}{*}{$\begin{array}{c}\text { Diam- } \\
\text { eter } \\
\text { (inches) }\end{array}$} & \multicolumn{2}{|c|}{ Screen } & \multicolumn{5}{|c|}{ Elevation (feet above mean sea level) of- } \\
\hline & & & & & & & & 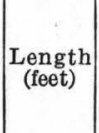 & $\begin{array}{c}\text { Slot } \\
\text { (inches) }\end{array}$ & $\begin{array}{l}\text { Top of } \\
\text { casing }\end{array}$ & $\begin{array}{c}\text { Land } \\
\text { surface }\end{array}$ & $\begin{array}{c}\text { Bottom } \\
\text { of } \\
\text { screen }\end{array} \mid$ & $\begin{array}{l}\text { Bed- } \\
\text { rock }\end{array}$ & $\begin{array}{l}\text { Water } \\
\text { level on } \\
\text { comple- } \\
\text { tion } \\
\text { of well }\end{array}$ \\
\hline $42-16-20$ & D3 & (3) $\ldots \ldots \ldots$ & \multirow{2}{*}{$\begin{array}{l}\text { Louisville Gas and } \\
\text { Electric Co. }\end{array}$} & V & \multirow{2}{*}{$\begin{array}{l}6-15-46 \\
6-21-46\end{array}$} & \multirow{2}{*}{$\begin{array}{l}91.0 \\
95.2\end{array}$} & \multirow{2}{*}{$\begin{array}{l}4 \\
4\end{array}$} & 2 & \multirow{3}{*}{$\begin{array}{r}1 '-010 \\
1^{\prime}-.020 \\
1^{\prime}-.010 \\
1^{\prime}-.020 \\
.030 \\
.030 \\
.030 \\
.030 \\
.030 \\
.030\end{array}$} & \multirow{2}{*}{$\begin{array}{l}426.72 \\
428.28\end{array}$} & \multirow{2}{*}{$\begin{array}{l}425.7 \\
425.7\end{array}$} & \multirow{2}{*}{$\begin{array}{l}335.9 \\
341.3\end{array}$} & 334.7 & 419.74 \\
\hline $42-16-21$ & $\mathrm{R} 1$ & (3) $\ldots$ & & V & & & & 2 & & & & & 335.5 & 419.95 \\
\hline $\begin{array}{l}42-16-22 \\
42-16-23 \\
42-16-24 \\
42-16-25 \\
42-16-26 \\
42-16-27\end{array}$ & $\begin{array}{l}\mathrm{L} 2 \\
\mathrm{~L} 3 \\
\mathrm{~L} 1 \\
\mathrm{U} 1 \\
\mathrm{U} 2 \\
\mathrm{D} 2\end{array}$ & (3) (3) & $\begin{array}{l}\text { City of Louisville and } \\
\text { Louisville Gas and } \\
\text { Electric Co. }\end{array}$ & $\begin{array}{l}\mathrm{V} \\
\mathrm{V} \\
\mathrm{V} \\
\mathrm{V} \\
\mathrm{V} \\
\mathrm{V}\end{array}$ & $\begin{array}{l}6-27-46 \\
6-28-46 \\
7-1-46 \\
7-3-46 \\
7-9-46 \\
7-11-46\end{array}$ & $\begin{array}{l}97.0 \\
95.3 \\
94.2 \\
90.0 \\
90.5 \\
91.0\end{array}$ & $\begin{array}{l}4 \\
4 \\
4 \\
4 \\
4 \\
4 \\
4\end{array}$ & $\begin{array}{l}2 \\
2 \\
2 \\
2 \\
2 \\
2\end{array}$ & & $\begin{array}{l}437.34 \\
436.50 \\
431.90 \\
427.46 \\
428.01 \\
427.18\end{array}$ & $\begin{array}{l}434.4 \\
433.0 \\
430.4 \\
425.7 \\
425.3 \\
425.8\end{array}$ & $\begin{array}{l}351.4 \\
352.6 \\
351.6 \\
335.7 \\
335.2 \\
335.3\end{array}$ & $\begin{array}{l}337.4 \\
337.8 \\
336.2 \\
335.7 \\
334.8 \\
334.8\end{array}$ & $\begin{array}{l}420.03 \\
419.60 \\
420.01 \\
419.47 \\
418.65 \\
419.75\end{array}$ \\
\hline $\begin{array}{l}42-16-28 \\
42-16-29 \\
42-16-30 \\
42-16-31 \\
42-16-32 \\
42-16-33 \\
42-16-34\end{array}$ & $\begin{array}{l}\text { D1 } \\
\text { R2 } \\
\text { R1T } \\
\text { L1T } \\
\text { U1T } \\
\text { U2T } \\
\text { D1T }\end{array}$ & $\begin{array}{l}\text { (3) } \\
(3) \\
(3) \\
(3) \\
(3) \\
(3) \\
(3)\end{array}$ & \multirow[t]{2}{*}{$\begin{array}{l}\text { City of Louisville. } \\
\text { Louisville Gas and } \\
\text { Electric Co. }\end{array}$} & $\begin{array}{l}\text { V } \\
\text { V } \\
\text { V } \\
\text { V } \\
\text { V } \\
\text { V } \\
\text { V }\end{array}$ & $\begin{array}{l}7-16-46 \\
7-20-46 \\
7-19-46 \\
7-1-46 \\
7-3-46 \\
7-9-46 \\
7-11-46\end{array}$ & $\begin{array}{l}90.5 \\
87.0 \\
53.2 \\
33.0 \\
26.1 \\
26.5 \\
28.3\end{array}$ & \begin{tabular}{l|}
4 \\
4 \\
$11 / 4$ \\
$11 / 4$ \\
$11 / 4$ \\
$11 / 4$ \\
$11 / 4$
\end{tabular} & $\begin{array}{l}2 \\
2 \\
3 \\
3 \\
3 \\
3 \\
3\end{array}$ & $\begin{array}{l}.030 \\
.030 \\
.010 \\
.010 \\
.010 \\
.010 \\
.010\end{array}$ & $\begin{array}{l}428.74 \\
422.63 \\
426.53 \\
430.91 \\
426.28 \\
426.30 \\
426.44\end{array}$ & $\begin{array}{l}425.9 \\
420.6 \\
425.7 \\
430.4 \\
425.7 \\
425.3 \\
425.9\end{array}$ & \begin{tabular}{l|}
335.5 \\
334.8 \\
371.7 \\
397.4 \\
399.6 \\
398.8 \\
397.6
\end{tabular} & $\begin{array}{r}335.4 \\
333.6 \\
\hdashline-1 \\
\hdashline-.- \\
\hdashline-1 .-\end{array}$ & $\begin{array}{l}419.63 \\
419.53 \\
419.53 \\
419.42 \\
419.43 \\
419.45 \\
419.44\end{array}$ \\
\hline $\begin{array}{l}42-16-35 \\
42-16-36\end{array}$ & $\begin{array}{l}\text { R2T } \\
\text { R3T }\end{array}$ & In Ohio River ${ }^{3}$ & & $\begin{array}{l}\mathrm{V} \\
\mathrm{R}\end{array}$ & $\begin{array}{r}7-19-46 \\
10-7-46\end{array}$ & $\begin{array}{r}36.9 \\
430.1\end{array}$ & $11 / 4$ & 3 & .010 & $\begin{array}{l}421.16 \\
421.33\end{array}$ & $\begin{array}{l}420.6 \\
409.0\end{array}$ & $\begin{array}{l}383.7 \\
378.9\end{array}$ & - & $\begin{array}{l}419.49 \\
419.83\end{array}$ \\
\hline $42-16-37$ & PW & (3) & \multirow{3}{*}{$\begin{array}{l}\text { Commonwealth of } \\
\text { Kentucky. } \\
\text { Louisville Gas and } \\
\text { Electric Co. } \\
\text { Commonwealth of } \\
\text { Kentucky. }\end{array}$} & $\mathbf{R}$ & $9-17-46$ & 90.0 & 12 & 30 & $(8)$ & 426.03 & 425.7 & 335.7 & 335.7 & $\begin{array}{l}419.80 \\
419.38\end{array}$ \\
\hline $42-16-38$ & R5 & In Ohio River ${ }^{3}$ & & $\mathbf{R}$ & $10-7-46$ & ${ }^{4} 50.4$ & $61 / 2$ & 5.4 & .2 & 423.48 & 386.0 & 346.7 & 335.6 & 419.41 \\
\hline $\begin{array}{l}42-16-39 \\
42-16-40 \\
42-16-41\end{array}$ & $\begin{array}{c}\mathrm{R} 4 \\
\mathrm{R3} \\
\mathrm{U} 3 \mathrm{~T}\end{array}$ & $\begin{array}{l}\text { In Ohio River }{ }^{3} \\
\text { In Ohio River }{ }^{3}\end{array}$ & & $\begin{array}{l}\mathrm{R} \\
\mathrm{R} \\
\mathrm{U}\end{array}$ & $\begin{array}{l}10-5-46 \\
10-7-46 \\
10-23-46\end{array}$ & $\begin{array}{r}452.0 \\
472.0 \\
16.0\end{array}$ & $\begin{array}{l}61 / 2 \\
61 / 2 \\
4\end{array}$ & $\begin{array}{r}10 \\
7.2 \\
\text { None }\end{array}$ & $\begin{array}{l}.2 \\
\text { Nione }\end{array}$ & $\begin{array}{l}423.90 \\
422.31 \\
424.50\end{array}$ & $\begin{array}{l}388.8 \\
409.0 \\
424.2\end{array}$ & $\begin{array}{l}348.6 \\
350.8\end{array}$ & $\begin{array}{l}336.8 \\
337.0\end{array}$ & $\begin{array}{l}419.42 \\
419.66 \\
421.60\end{array}$ \\
\hline $43-16-7$ & $-\ldots$ & $\begin{array}{l}50 \mathrm{ft} \text { from river edge, } 1,200 \mathrm{ft} \\
\text { upstream from mouth of Bear- }\end{array}$ & Nugent Sand Co & $\vec{v}$ & $4-9-46$ & 90.6 & 4 & 2 & .010 & 429.11 & 425.1 & 337.7 & 337.3 & 419.10 \\
\hline $43-16-8$ & & $\begin{array}{l}115 \mathrm{ft} \text { northwest of River Road, } \\
1,100 \mathrm{ft} \text { northeast of Beargrass } \\
\text { Creek bridge. }\end{array}$ & City of Louisville...... & $\nabla$ & $4-2-46$ & 105.3 & 4 & 2 & .010 & 439.97 & 438.8 & 337.4 & 337.3 & 416. 68 \\
\hline $\begin{array}{l}1 \text { Wate } \\
21 \mathrm{ft} .0 \\
8 \text { Pum } \\
\text { ville Wa } \\
\text { i Belo }\end{array}$ & $\begin{array}{l}\text { aping test } \\
\text { ater Co. I } \\
\text { w river b }\end{array}$ & $\begin{array}{l}\text { ane } 20,1946 . \\
\text { slot and } 1 \mathrm{ft} \text {. of } 3 / 32 \text {-in holes. } \\
\text { area. Located along river } 300 \mathrm{ft} \text {. } \\
\text { ?umping Station. }\end{array}$ & 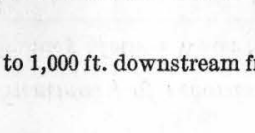 & & & $\begin{array}{l}\text { creen: } \\
\text { Ele } \\
365.7 \text { to } \\
360.7 \text { to } \\
345.7 \text { to }\end{array}$ & $\begin{array}{ll}\text { tion } \\
0.7- \\
0.7 .-\end{array}$ & & & & & & & $\begin{array}{r}\begin{array}{c}\text { Slot } \\
\text { (inches) }\end{array} \\
-0.020 \\
\hdashline \quad .100 \\
\hdashline \quad .020\end{array}$ \\
\hline
\end{tabular}


The fill of glacial-outwash and Recent deposits averages about 100 feet thick. The Ohio River, ranging from 2,000 to 3,000 feet in width, flows through the central part of the valley, making a gentle bend to the right. The distance from the southeastern valley wall to the river is about 3,000 feet at the northeastern end of the area, 1,000 feet at Goose Island, and 3,500 feet at the southwestern end. The Kentucky side of the valley is transversed by Harrods Creek and Goose Creek in the northeast part and Beargrass Creek in the southwest; Muddy Fork of Beargrass Creek flows southwest along the valley wall in the southwestern half of the area.

Elevations of the bedrock underlying the glacial-outwash deposits are shown on the map of bedrock elevations (pl. 3) and the cross sections, (pl. 4). The illustrations are based on data collected during test drilling and on information furnished by drillers and owners of wells. The valley cut in the bedrock is much narrower than in the area to the southwest, where it approaches 6 miles in width and contains several old channels. ${ }^{3}$

The valley floor was eroded to an elevation of about 335 feet above mean sea level. Downstream the composition of the bedrock ranges upward through the stratigraphic section from the Liberty formation of the Richmond group (Ordovician system) in the vicinity of Goose Island, through the Saluda limestone of the same group at Blankenbaker Lane, the Brassfield limestone (Silurian system), the Osgood formation (Silurian system) at Indiana Hills Trail, to the Laurel dolomite (Silurian system) in the southwest part of the area (Butts, 1915). Wells drilled into these formations cannot be expected to yield large supplies of ground water. ${ }^{4}$

Above the Laurel dolomite and underlying the upland area to the southeast is the Waldron shale of the Silurian system. This formation, about 10 feet thick, acts as an effective barrier to percolation of water vertically downward to the lower formations. Above the Waldron shale three formations are exposed in the upland area southeast of the valley: the Louisville limestone of the Silurian system and the Jeffersonville and Sellersburg limestones of the Devonian system. Those limestones are moderately jointed. The joints have been solutionally developed by water precipitated on the upland area. Ground-water flow in the rocks is governed by the geologic conditions: part of the water precipitated on the upland area travels vertically downward through solutionally developed joints in the limestone formations until blocked by the Waldron shale or by zones of limestone of low solubility; the water then flows down the dip in a westerly

\footnotetext{
${ }^{3}$ Rorabaugh, M. I, op cit., p. 3.

4 Hamilton, D. K., 1944, Ground water in the bedrock beneath the glacial outwash in the Louisville area, Kentucky. Prepared by the Geological Surver, in cooperation with the Geological Division, Kentucky State Department of Mines and Minerals, August. (Manuscript report in files of U. S. Geological Survey.)
} 
direction to the valley wall, which cuts these formations, and enters the Pleistocene glacial-outwash material.

The valley cut in the bedrock has been partly filled with different mixtures of sand and gravel to an average elevation of 410 feet above mean sea level. A deposit of Recent alluvium consisting of silt, clay, and fine sand, ranging from 15 to 30 feet in thickness, covers the outwash material. Drilling in the river at the site of the pumping test showed that the bottom of this nearly impervious layer slopes northwest to an elevation of about 385 feet about 50 feet beyond the edge of the river, and that the layer tapers out to a feather edge about 100 feet from the river bank. Beyond this point the river is flowing on sand and gravel. This condition is similar to those encountered at Lees Lane and at Bells Lane, southwest of Louisville. It is thought that this "clay lip" extending downward under the edge of the river was deposited by floods prior to construction of dam 41 at Louisville. Construction of the dam several miles downstream raised the normal pool elevation of the river to 419.5 feet above mean sea level (1912 adjustment).

\section{LABORATORY ANALYSIS OF GEOLOGIC SAMPLES}

Tests to determine the permeability of the water-bearing sands and gravels were made in the laboratory for each sample obtained from the test wells, using a variable-head permeameter similar to that described by Fishel (1942, p. 59). Laboratory values of permeability expressed in $\mathrm{gpd} / \mathrm{ft}^{2}$ under a head of unity and temperature of $60^{\circ} \mathrm{F}$., are shown on plate 5 .

Although the permeability results obtained in the laboratory do not compare in accuracy to those obtained by field pumping tests, the results are sufficiently accurate to permit making general comparisons between one location and another and also of the relative permeability of samples from different depths in the same well.

\section{WATER-LEVEL MEASUREMENTS AND FLUCTUATIONS}

Records of water level were obtained at one well (No. 43-15-1) from 1937 to 1943 by the city of Louisville and since 1943 by the U. S. Geological Survey. Records have been collected at 14 wells (solid circles on pl. 2) since 1943, at 6 test wells (open squares on pl. 2) since 1944 , and at 30 test wells (open circles on pl. 2) since 1946. Measurements were made by steel tape at least once per month; additional readings were obtained during river floods; automatic float-type recorders were maintained for several months on all test wells.

Ground-water levels in the area respond to changes in river elevation. Figure 5 shows graphs of river elevation and of water-leve] 


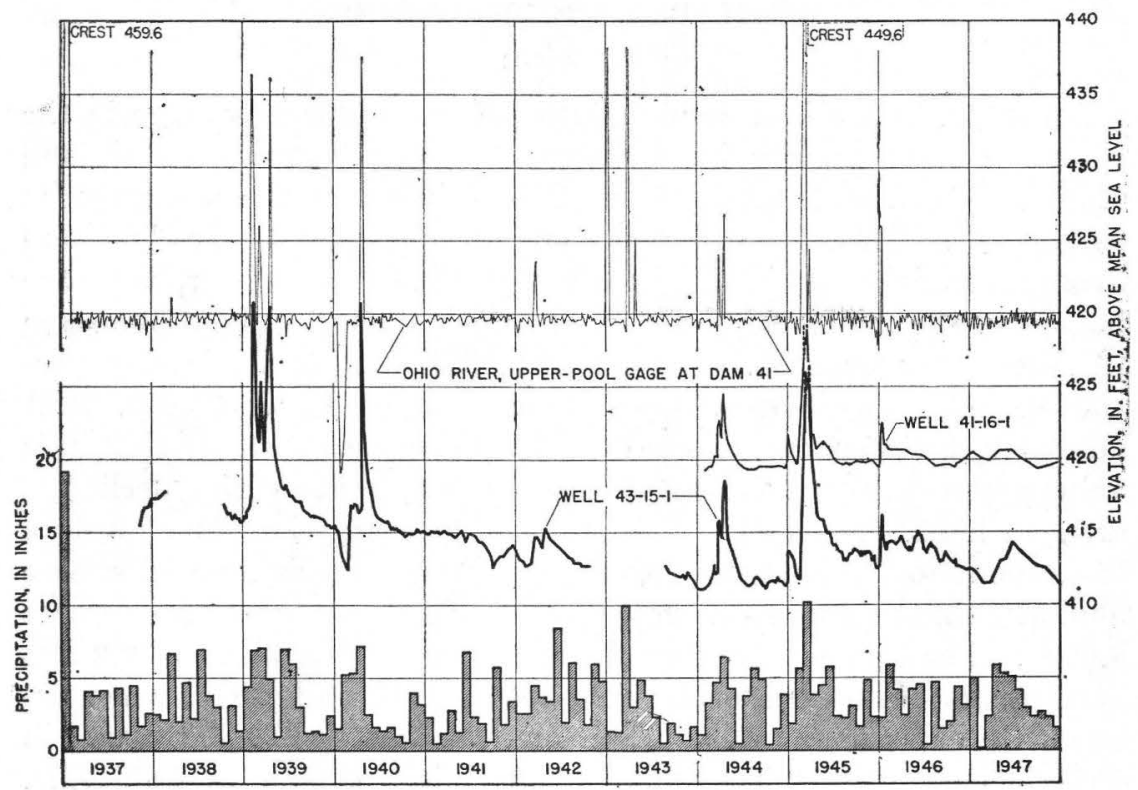

FIGURE 5.-Graphs of precipitation, river elevation, and ground-water elevation, 1937-47, in northeastern part of Louisville area.

elevation in two wells. The graph of water level in well 43-15-1, about 2,400 feet from the river, clearly shows the effect of river floods and the sharp drop in February 1940 when the river pool was lowered to clear the river of ice. The graph for this well declines during the 11-year period, showing that the heavy pumping in the downtown area of Louisville was removing water from storage in the southwestern part of the area covered in the present report.

In the area downstream from Wagners Lane, water levels are affected by local pumping; upstream from Wagners Lane water levels are unaffected by pumping. The graph of water levels in well 41-16-1, about 2,000 feet from the river and in the unpumped area, correlates both with river-level changes and with rainfall. The rise in water level during April 1947, a year when the river was essentially at pool stage and fluctuated only in a narrow range, reflects the direct effect of rain water infiltrating into the aquifer, an increase of flow from the consolidated rocks in the upland southwest of the river valley, or both. It is noted that during the dry summer months the water level in this well recedes and approaches river level as a base. Ground-water flow across the area to the river follows the annual precipitation cycle for the area, being greatest in the spring and least in the fall. 


\section{AVAILABLE GROUND WATER}

STORAGE

An estimate has been made of the ground water in storage in the glacial-outwash aquifer in the area between Beargrass Creek and Harrods Creek and between the Ohio River and the southeastern valley wall. This area of about 3 square miles in 6.4 miles long and averages slightly less than half a mile wide. The aquifer, from the bottom of the silt and clay cover to bedrock, averages about 60 feet in thickness over the area. A value of 0.0003 was obtained for the coefficient of storage from results of the pumping test. (See p. 148.) However, artesian conditions existed during this test, so that this value applies only to the water released from storage with a decline of artesian head. Exclusive of infiltration, lowering the water level 15 feet, about to the bottom of the fine-grained material, would release about $2 \frac{1}{2}$ million gallons of water if the coefficient of storage averages 0.0003 . For further lowering of the water level a value of 0.2 has been assumed as the specific yield of the sand and gravel when dewatered. This figure is based on computations by W. T. Stuart ${ }^{5}$ in 1944 in connection with studies of artificial recharge at Louisville. Stuart, who studied the recovery of water levels in 22 observation wells, found that computed values of specific yield varied from 0.16 to 0.22 .

The total ground-water storage in the area is estimated as about 7 billion gallons. Because it would be impractical to remove all the water, the storage estimate might better be stated as about 100 million gallons per vertical foot of the glacial-outwash aquifer.

\section{FLOW OF GROUND WATER}

Estimates of the rate of flow of ground water in the area have been made, based on the contour map of water levels for August 15, 1946 (pl. 6). The Ohio River had been at pool stage for the preceding 7 months, so that the water levels shown on the map for August reflect conditions unaffected by river floods. In making flow estimates a figure for transmissibility of $120,000 \mathrm{gpd} / \mathrm{ft}$ was used. This value was determined from the pumping test (p. 146) and is conservative. Comparison of laboratory permeabilities (pl. 5) indicates that the transmissibility is reasonably uniform throughout the area, though some difference occurs from one place to another.

In the unpumped area northeast of Wagners Lane, the flow is from the upland area northwestward through the outwash to the river.

S Stuart, W. T., 1944, Conservation of ground water, including artificial recharge, by two companies in the Louisville area, Kentucky. Prepared by the Geological Survey, in cooperation with the Geological Division, Kentucky State Department of Mines and Minerals, July. (Manuscript report in files of U. S. Geological Survey.) 
The ground-water discharge to the river in the part of the area northeast of Wagners Lane is estimated as 900,000 gpd, or about 200,000 gpd per mile of river.

The effect of heavy pumping in the downtown section of Louisville is apparent in the southwestern portion of the area. In the strip between Wagners Lane and Zorn (Pipeline) Avenue, water from the consolidated rocks enters the glacial outwash, then flows parallel to the river toward the downtown area. Flow parallel to the river in this section is estimated as about 70,000 gpd.

In the area between Zorn Avenue and Beargrass Creek the flow estimates are as follows:

Flow-

From river toward area, 500,000 gpd.

Parallel to river from northeast, 70,000 gpd.

From consolidated rocks, 250,000 gpd.

Estimated pumpage in area, 450,000 gpd.

Flow out of area toward downtown cone, $370,000 \mathrm{gpd}$.

These estimates were made on basis of conditions prevailing in August 1946 and reflect less-than-average flows. During and following the period of heaviest rainfall (February to May), a period when evaporation and transpiration losses are small, the water levels are at their highest, gradients are steepest, and flow is greatest. In August 1946, during the season of light precipitation and at a time when losses by evaporation and transpiration were high, the waterlevel graphs show that the condition under study was at a relatively low point on the recession curve.

In the winter months pumpage by the Louisville Gas and Electric Co. is increased, so that the total pumpage in the area approximates 950,000 gpd. During this season the gradients from the river are increased and those toward the downtown area are decreased, so that flow from the river is larger and that toward the downtown area is somewhat reduced.

In studying ground-water flow in the area southwest of Louisville ${ }^{6}$ it was found that the recharge by vertical percolation of water from rainfall to the glacial outwash approximated 6 inches of water in 1945, a year of above-average precipitation. It is estimated that the accretion to ground water from precipitation on the area under investigation amounts to an average of about 700,000 gpd. Practically all the recharge occurs late in winter and in spring, a period when precipitation is heavy, soil moisture is high prior to the growing season, and evaporation and transpiration are low. In making the August

\footnotetext{
- Rorabaugh, M. I., 1946, Ground-water resources of the southwestern part of the Louisville area, Ken. tucky, p. 35. Prepared by the Geological Survey, in cooperation with the Rubber Reserve Company, the city of Louisville, and Jefferson County, December. (Manuscript report in files of U. S. Geol. Survey.),
} 
flow estimates no recharge from rainfall was considered because the late-summer precipitation was insufficient to meet the requirements of evaporation, transpiration, and seil moisture.

\section{MINERAL QUALITY OF WATER}

Water samples were obtained at the conclusion of the drilling of each observation well. Partial chemical analyses were made in the laboratory of the Geological Survey. Table 3 shows the results of these analyses. In addition, table 4 presents analyses of samples collected from production wells in the area. Detailed analyses are given in table 5 for water from the pumping-test well, both at the beginning of the test and after 15 days of pumping at approximately $1,100 \mathrm{gpm}$, and for water from a producing well in the area. Analyses of daily samples taken during the pumping test are given in the section on infiltration.

TABLE 3.-Partial chemical analyses, in parts per million, of water from test wells drilled in connection with the ground-water investigation northeast of Louisville

[Analyses by M. E. Schroeder, Geological Survey. Iron in solution; water was filtered at time of sampling]

\begin{tabular}{|c|c|c|c|c|c|c|c|c|c|}
\hline Well No. & $\begin{array}{l}\text { Pumping } \\
\text { test No. }\end{array}$ & $\begin{array}{l}\text { Date } \\
\text { sample } \\
\text { collected }\end{array}$ & $\begin{array}{l}\text { Temper- } \\
\text { ature } \\
\text { ( F.) }\end{array}$ & $\begin{array}{l}\text { Iron } \\
(\mathrm{Fe})\end{array}$ & $\begin{array}{c}\text { Bicar- } \\
\text { bonate } \\
\left(\mathrm{HCO}_{3}\right)\end{array}$ & $\begin{array}{c}\text { Sulfate } \\
\left(\mathrm{SO}^{4}\right)\end{array}$ & $\begin{array}{l}\text { Chloride } \\
\text { (Cl) }\end{array}$ & $\begin{array}{l}\text { Nitrate } \\
\left(\mathrm{NO}_{4}\right)\end{array}$ & $\begin{array}{c}\text { Total } \\
\text { hardness } \\
\text { as } \mathrm{CaCO}_{3}\end{array}$ \\
\hline $\begin{array}{l}38-19-2 \\
39-18-1 \\
40-17-3 \\
40-17-4 \\
40-17-5\end{array}$ & (1.2- & $\begin{array}{l}8-3-46 \\
7-31-46 \\
5-29-46 \\
6-4-46 \\
6-6-46\end{array}$ & $\begin{array}{l}57 \\
57 \\
57 \\
55 \\
58\end{array}$ & $\begin{array}{l}0.10 \\
.63 \\
1.0 \\
4.0 \\
.25\end{array}$ & $\begin{array}{l}314 \\
368 \\
309 \\
402 \\
379\end{array}$ & $\begin{array}{l}46 \\
46 \\
48 \\
56 \\
69\end{array}$ & $\begin{array}{r}3 \\
5 \\
6 \\
12 \\
9\end{array}$ & $\begin{array}{r}0.4 \\
.4 \\
.2 \\
.9 \\
.9\end{array}$ & $\begin{array}{l}322 \\
352 \\
308 \\
375 \\
390\end{array}$ \\
\hline $\begin{array}{l}41-16-2 \\
41-16-3 \\
41-16-4 \\
41-17-2 \\
41-17-3\end{array}$ & \begin{tabular}{|} 
L5 $\ldots . .$. \\
L4 \\
\\
\hdashline
\end{tabular} & $\begin{array}{l}4-18-46 \\
4-23-46 \\
5-21-46 \\
5-17-46 \\
5-23-46\end{array}$ & $\begin{array}{l}57 \\
58 \\
57 \\
58 \\
58\end{array}$ & $\begin{array}{l}1.5 \\
1.2 \\
.39 \\
.27 \\
.44\end{array}$ & $\begin{array}{l}365 \\
301 \\
363 \\
352 \\
354\end{array}$ & $\begin{array}{l}49 \\
31 \\
43 \\
32 \\
32\end{array}$ & $\begin{array}{r}49 \\
5 \\
7 \\
12 \\
10\end{array}$ & $\begin{array}{l}.4 \\
.4 \\
.2 \\
.7 \\
.2\end{array}$ & $\begin{array}{l}368 \\
285 \\
352 \\
338 \\
315\end{array}$ \\
\hline $\begin{array}{l}42-16-15 \\
42-16-16 \\
42-16-17 \\
42-16-18 \\
42-16-19\end{array}$ & $\mathrm{D} 4$ & $\begin{array}{l}4-30-46 \\
5-4-46 \\
5-9-46 \\
6-8-46 \\
6-12-46\end{array}$ & $\begin{array}{l}57 \\
57 \\
58 \\
57 \\
58\end{array}$ & $\begin{array}{r}.18 \\
.27 \\
1.1 \\
.10 \\
1.12\end{array}$ & $\begin{array}{l}376 \\
376 \\
288 \\
373 \\
290\end{array}$ & $\begin{array}{r}196 \\
63 \\
29 \\
67 \\
88\end{array}$ & $\begin{array}{r}15 \\
4 \\
15 \\
12 \\
9\end{array}$ & $\begin{array}{l}.6 \\
.5 \\
.5 \\
.0 \\
.2\end{array}$ & $\begin{array}{l}495 \\
368 \\
285 \\
368 \\
278\end{array}$ \\
\hline $\begin{array}{l}42-16-20 \\
42-16-21 \\
42-16-22 \\
42-16-23 \\
42-16-24\end{array}$ & $\begin{array}{l}\mathrm{D} 3 \ldots \\
\mathrm{R} 1 \ldots \\
\mathrm{L} 2 \ldots \\
\mathrm{L} 3 \ldots \\
\mathrm{L} 1 \ldots\end{array}$ & $\begin{array}{l}6-15-46 \\
6-21-46 \\
6-27-46 \\
6-28-46 \\
7-1-46\end{array}$ & $\begin{array}{l}58 \\
58 \\
57.5 \\
56.5 \\
56.4\end{array}$ & $\begin{array}{l}.15 \\
.13 \\
.27 \\
.10 \\
.22\end{array}$ & $\begin{array}{l}381 \\
381 \\
377 \\
374 \\
384\end{array}$ & $\begin{array}{r}92 \\
195 \\
100 \\
273 \\
191\end{array}$ & $\begin{array}{l}10 \\
17 \\
13 \\
22 \\
16\end{array}$ & $\begin{array}{l}.0 \\
.0 \\
.1 \\
.4 \\
.2\end{array}$ & $\begin{array}{l}420 \\
518 \\
435 \\
455 \\
502\end{array}$ \\
\hline $\begin{array}{l}42-16-25 \\
42-16-26 \\
42-16-27 \\
42-16-28 \\
42-16-29\end{array}$ & $\begin{array}{l}\mathrm{U} 1 \ldots \\
\mathrm{U} 2 \ldots \\
\mathrm{D} 2 \ldots \\
\mathrm{D} 1 \\
\mathrm{R} 2 \ldots\end{array}$ & $\begin{array}{l}7-3-46 \\
7-9-46 \\
7-11-46 \\
7-16-46 \\
7-20-46\end{array}$ & $\begin{array}{l}57 \\
58 \\
57 \\
57 \\
58\end{array}$ & $\begin{array}{r}.11 \\
.20 \\
13.0 \\
.07 \\
.17\end{array}$ & $\begin{array}{l}400 \\
110 \\
387 \\
353 \\
388\end{array}$ & $\begin{array}{r}223 \\
74 \\
136 \\
75 \\
176\end{array}$ & $\begin{array}{l}17 \\
50 \\
15 \\
51 \\
15\end{array}$ & $\begin{array}{l}.1 \\
.1 \\
.3 \\
.2 \\
.1\end{array}$ & $\begin{array}{l}540 \\
218 \\
480 \\
435 \\
428\end{array}$ \\
\hline $\begin{array}{r}42-16-38 \\
42-16-39 \\
42-16-40 \\
43-16-7 \\
43-16-8\end{array}$ & $\begin{array}{l}\mathrm{R} 5 \\
\mathrm{R} 4 \\
\mathrm{R} 3\end{array}$ & $\begin{array}{r}10-4-46 \\
10-6-46 \\
10-7-46 \\
4-9-46 \\
4-2-46\end{array}$ & $\begin{array}{l}62 \\
62 \\
59 \\
58\end{array}$ & $\begin{array}{l}4.5 \\
.97 \\
.99 \\
1.3\end{array}$ & $\begin{array}{l}338 \\
370 \\
366 \\
317 \\
269\end{array}$ & $\begin{array}{r}49 \\
140 \\
177 \\
29 \\
43\end{array}$ & $\begin{array}{l}12 \\
17 \\
17 \\
12 \\
16\end{array}$ & $\begin{array}{r}1.6 \\
.5 \\
.1 \\
.4 \\
.7\end{array}$ & $\begin{array}{l}312 \\
339 \\
342 \\
292 \\
258\end{array}$ \\
\hline
\end{tabular}

${ }^{1}$ Iron in solution (filtered), 0.12; total iron (sample not filtered), 3.4. 
$\mathrm{T}_{\mathrm{ABLE}}$ 4.-Partial chemical analyses, in parts per million, of water from production wells in northeastern part of Louisville area [Analyses made by E. W. Lohr or J. H. White, U. S. Geological Survey]

\begin{tabular}{|c|c|c|c|c|c|c|c|c|c|c|}
\hline Well No, & Owner & $\begin{array}{c}\text { Date } \\
\text { sámple } \\
\text { collected }\end{array}$ & $\begin{array}{c}\text { Temper- } \\
\text { ature } \\
\left({ }^{\circ} \mathrm{F}\right)\end{array}$ & $\mathrm{pH}$ & $\begin{array}{l}\text { Iron } \\
(\mathrm{Fe})\end{array}$ & $\begin{array}{c}\text { Bicar- } \\
\text { bonate } \\
\left(\mathrm{HCO}_{3}\right)\end{array}$ & $\underset{\left(\mathrm{SO}_{4}\right)}{\text { Sulfate }}$ & $\begin{array}{l}\text { Chloride } \\
\text { (Cl) }\end{array}$ & $\begin{array}{l}\text { Nitrate } \\
\left(\mathrm{NO}_{3}\right)\end{array}$ & $\begin{array}{c}\text { Total } \\
\text { hardness } \\
\text { as } \mathrm{CaCO}_{3}\end{array}$ \\
\hline $42-16-2$ & Louisville Gas and Electric Co & $\begin{array}{l}4-11-44 \\
8-24-44 \\
5-17-45 \\
8-21-46 \\
9-26-47\end{array}$ & $\begin{array}{l}64 \\
61 \\
61 \\
57\end{array}$ & 7.0 & $\begin{array}{l}1.5 \\
3.8 \\
2.5 \\
3.3 \\
2.2\end{array}$ & $\begin{array}{l}406 \\
394 \\
382 \\
368 \\
376\end{array}$ & $\begin{array}{l}86 \\
89 \\
85 \\
82 \\
86\end{array}$ & $\begin{array}{l}26 \\
18 \\
19 \\
24 \\
20\end{array}$ & $\begin{array}{l}0.0 \\
.2 \\
.1 \\
.1 \\
.1\end{array}$ & $\begin{array}{l}390 \\
398 \\
398 \\
420 \\
345\end{array}$ \\
\hline 43-15-9 & General Distillers. & $\begin{array}{l}8-22-44 \\
5-17-45\end{array}$ & $\begin{array}{r}59 \\
-\ldots\end{array}$ & 7.1 & $\begin{array}{l}.67 \\
.70\end{array}$ & $\begin{array}{l}494 \\
418\end{array}$ & $\begin{array}{l}72 \\
76\end{array}$ & $\begin{array}{l}51 \\
32\end{array}$ & $\begin{array}{l}4.8 \\
5.5\end{array}$ & $\begin{array}{l}450 \\
420\end{array}$ \\
\hline $43-16-6$ & Jeffersonville Boat and Machine Co & $\begin{array}{l}4-13-44 \\
8-30-44 \\
5-17-45 \\
8-23-46\end{array}$ & $\begin{array}{c}59 \\
59 \\
60\end{array}$ & $\begin{array}{r}7.2 \\
-2\end{array}$ & $\begin{array}{r}.86 \\
.08 \\
3.4\end{array}$ & $\begin{array}{l}444 \\
444 \\
454 \\
508\end{array}$ & $\begin{array}{l}133 \\
157 \\
124 \\
154\end{array}$ & $\begin{array}{l}32 \\
32 \\
27 \\
33 \\
y\end{array}$ & $\begin{array}{l}11 \\
12 \\
7.6 \\
22\end{array}$ & $\begin{array}{l}480 \\
465 \\
480 \\
555\end{array}$ \\
\hline
\end{tabular}


TABLE 5.-Chemical analyses, in parts per million, of water from wells in northeastern part of Louisville area

[Analyses made by E. W. Lohr or A. Theriault, Geological Survey]

\begin{tabular}{|c|c|c|c|}
\hline & \multicolumn{3}{|c|}{ Well No. } \\
\hline & $42-16-371$ & $42-16-37^{2}$ & $43-15-9$ \\
\hline Property owner.-.-. & \multirow{2}{*}{$\begin{array}{c}\text { City of } \\
\text { Louisville } \\
10-21-46\end{array}$} & \multirow{2}{*}{$\begin{array}{c}\text { City of } \\
\text { Louisville } \\
11-5-46\end{array}$} & \multirow{2}{*}{$\begin{array}{c}\text { General } \\
\text { Distillers } \\
4-6-44\end{array}$} \\
\hline Date sample collected......... & & & \\
\hline $\begin{array}{l}\text { Silica }\left(\mathrm{SiO}_{2}\right) \\
\text { Iron }(\mathrm{Fe}) \text {, in solution }\end{array}$ & \multirow{12}{*}{$\begin{array}{c}12 \\
.04 \\
2.1 \\
145 \\
35 \\
9.8 \\
1.7 \\
0 \\
376 \\
186 \\
16 \\
.0 \\
616 \\
506\end{array}$} & \multirow{12}{*}{$\begin{array}{c}16 \\
.01 \\
1.9 \\
115 \\
28 \\
9.7 \\
1.6 \\
0 \\
343 \\
107 \\
16 \\
.1 \\
.1 \\
474 \\
402\end{array}$} & \multirow{2}{*}{${ }^{15} .94$} \\
\hline Total iron & & & \\
\hline Calcium (Ca) & & & 136 \\
\hline Magnesium $(\mathrm{Mg})$ & & & 30 \\
\hline Sodium (Na) & & & 24 \\
\hline $\begin{array}{l}\text { Potassium (K) } \\
\text { Carbonate }\left(\mathrm{CO}_{3}\right)\end{array}$ & & & $\begin{array}{l}3.4 \\
0\end{array}$ \\
\hline Bicarbonate $\left(\mathrm{HCO}_{3}\right)_{-}$ & & & 451 \\
\hline $\begin{array}{l}\text { Sulfate }\left(\mathrm{SO}_{4}\right) \\
\text { Chloride }(\mathrm{Cl})\end{array}$ & & & 73. \\
\hline $\begin{array}{l}\text { Chloride }(\mathrm{Cl}) \\
\text { Fluoride }(\mathrm{F})\end{array}$ & & & ${ }^{39} .1$ \\
\hline Nitrate $\left(\mathrm{NO}_{3}\right)$ & & & 4.0 \\
\hline Dissolved solids & & & 558 \\
\hline $\mathrm{Hardness}$ as $\mathrm{CaCO}_{3}$ & & & 463 \\
\hline $\begin{array}{l}\text { Temperature }\left({ }^{\circ} \mathrm{F}\right) \\
\mathrm{pH}\end{array}$ & $\begin{array}{r}56.5 \\
7.6\end{array}$ & $\stackrel{58}{7.7}$ & $\begin{array}{r}59 \\
7,1\end{array}$ \\
\hline
\end{tabular}

1 At start of pumping.

2 After pumping 15 days.

Inspection of the tables shows that the quality of the ground water is reasonably consistent throughout the area upstream from Zorn Avenue. A correlation with the quality of river water is not expected in this area because the flow is toward the river. In the area downstream from Zorn Avenue the quality of ground water appears to be affected by several factors. In the southeastern part of that area water from wells $42-16-17,43-16-7$, and $43-16-8$, near the river, is less hard than that for the remainder of the area, reflecting the effect of river water flowing toward the downtown area. The hardness of the river water ranges from 100 to $250 \mathrm{ppm}$. At the pumpingtest location sulfate and total hardness are quite variable and are considerably higher than at any other location. The only logical explanation is that there is an upward flow of water from the bedrock to the sand and gravel at this location. Inspection of the tables shows that water from pumped wells is harder than that from nearby unpumped wells. This seems to indicate that the bedrock probably is contributing a part of the water supply to the pumped wells. Analyses of samples collected throughout the Louisville area during the period 1943-47 show that in all areas not underlain by shale, the sulfate content and total hardness have been steadily increasing. Inasmuch as the geologic formations in the area under study differ from those in the heavily pumped sections of Louisville, it cannot be definitely concluded that the sulfate content and hardness would increase if the area were heavily pumped. However, there is a 
strong probability that this would occur, at least until the effect of infiltration from the river overcame the effects of the contribution of water from the bedrock. It is noted that pumped wells 43-15-9 and 42-16-2 and the pumping-test site lie on a straight line bearing approximately N. $30^{\circ} \mathrm{E}$. which coincides with the strike of one joint system in the bedrock. The above-average hardness of water from wells along this line may indicate upward flow of water from the consolidated rocks through joints.

\section{TEMPERATURE OF WATER}

Records of temperatures of water in observation wells have been obtained for several years. Temperatures were measured at 5 -foot intervals of depth by means of an electrical resistance thermometer. The temperature is reported as the average of the 5 -foot readings. Plate 7 shows the maximum and minimum temperatures recorded. The average temperature of ground water in the area is $56^{\circ} \mathrm{F}$. The maximum temperatures occur in October and November, the minimum in April and May. This cycle follows the air-temperature cycle with a lag of about 3 months, representing the time necessary for rainfall to become effective as recharge to the aquifer. The temperature range near the top of the aquifer is somewhat greater than near the bottom, as would be expected. The temperature at well 43-15-1 has a wider range than that in other wells in the area. Water temperatures in this well reflect the temperature of water recharged from Beargrass Creek, that of water in a large sewer near the well, and possibly the heat resulting from decomposition of trash in a dump near the well.

\section{THEORY OF INDUCED INFILTRATION}

\section{INTRODUCTION}

Ground-water flow is controlled in part by the thickness of the water-bearing material, by the permeability of the material, and by the hydraulic gradient. When a well is pumped or is allowed to flow the hydrostatic pressure near the well adjusts itself in the shape of an inverted cone so that Darcy's relationship, $Q=P I A$, is satisfied at any point. $(Q$ is the rate of flow; $P$, coefficient of permeability; $I$, hydraulic gradient; and $A$, the cross-sectional area perpendicular to the direction of flow.) If a well is placed near a surface source (a river, pond, or lake), the water being pumped will be replaced in part by water entering the aquifer from the surface supply. The shape of the cone of pressure distribution is then distorted so that gradients between the source and the well become steep in comparison to those on the side away from the source. All other factors being 
equal, the flow in the distorted cone will follow the Darcy relation; that is, the flow toward the well will be greatest on the side nearest the source where gradients are steepest. If pumping is continued for a long enough time, a condition of essentially steady flow will result, in which most of the pumped water will be derived from the surface source.

This principle has been utilized by three types of installations: vertical wells, infiltration galleries, and horizontal-type collectors. Each installation has its advantages and disadvantages. However, the basic factors affecting design are the same for each and consist of:

1. The permeability of the aquifer - a characteristic of the material related to its ability to transmit water. The coefficient of permeability of a material $(P)$ used in this report is expressed in Meinzer's units (Wenzel, 1942, p. 7) as the rate of flow of water in gallons per day, through a square foot of its cross section, under a hydraulic gradient of 100 percent, and at a temperature of $60^{\circ} \mathrm{F}$.

The coefficient of transmissibility (Theis, 1935, p. 520) is used in this report to denote the rate of flow of water in gallons per day, through a section of aquifer 1 foot wide, under a hydraulic gradient of 100 percent, at a temperature of $60^{\circ} \mathrm{F}$. As originally defined by Theis the coefficient of transmissibility is a field coefficient; hence the definition should read "at the prevailing temperature of the ground water." However because temperature is involved in these units and variation in it must be accounted for in test and design computations, the coefficient of transmissibility as used in this report is thus standardized at $60^{\circ} \mathrm{F}$. The coefficient of transmissibility is equal to the coefficient of permeability multiplied by the thickness of the saturated portion of the aquifer.

Because temperature is involved in these units, variation in it must be accounted for in test and design computations. In ground-water movement laminar flow usually prevails. For this condition the viscosity of the water changes about $1 \frac{1}{2}$ percent per degree (Fahrenheit) change of temperature. The rate of flow varies inversely as the viscosity; a rise of $1^{\circ}$ in ground-water temperature then will increase the rate of flow about $1 \frac{1}{2}$ percent.

2. The hydraulic gradient from the source to the installation. This gradient is made up of two dimensions:

a. The available head, or the difference in elevation between the source and the pumping level in the installation.

b. The distance from the point of entrance to the river or lake bed to the installation.

3. The vertical permeability of the river or lake bed, which may limit the rate of entrance of water to the aquifer. 
If these factors can be evaluated, the discharge of a production unit can be predicted if allowances are made for boundary conditions (artesian or free water table, barriers, zones of different transmissibility) and conditions of ground-water flow (direction, rate, steady or unsteady, uniform or nonuniform, interference).

Except for determining the limiting infiltration rate, the basic factors can be determined from a pumping test.

The objectives of conducting a pumping test are (1) to establish whether there is a hydraulic connection between the river and the aquifer, and (2) if infiltration is available, to determine the hydrologic characteristics of the aquifer so that quantitative estimates may be made of available supplies; specifically, to determine the transmissibility of the aquifer, and to determine at what effective distance from the river's edge the river water is entering the aquifer.

Infiltration into the river bed will take place over an area, but for simplification in computations the area is replaced by a "line source"; that is, the assumption is made that, so far as effects in observation wells are concerned, the water-levels will behave the same whether the water is entering over an area or at a line which is located at the effective or weighted-average distance to the area. This assumption will not be valid if observation wells are placed far enough out in the river to be within the area of recharge or if the pumped well is too close to the source. The distance from the pumped well to the line source is designated $a$.

For further simplification, the line source may be replaced by a recharging "image well" placed at a distance $a$ beyond the line source. The problem now is to evaluate the effect of a well discharging at a rate $Q$ and an image well a distance $2 a$ from the discharging well, recharging at the same rate.

The problem may be approached in either of two ways: (1) at any time study the shapes of the various profiles of drawdown based on a number of wells and (2) study the time-drawdown relationship at a given well.

\section{DRAWDOWN}

For development of equations, consider a homogeneous artesian aquifer of infinite extent with steady-flow conditions. Assume that pumping has continued long enough to establish equilibrium conditions. Also consider that barometric pressure and river elevation remain constant and that the temperature of the river water and water in the aquifer are equal and remain constant.

It can be shown by development of the Theis nonequilibrium equation (Wenzel, 1942, p. 87) or from the Thiem equation (Wenzel, 
1942 , p. 81) that the drawdown at any point for the conditions set forth above is

$$
s=\frac{2.30 Q \log _{10} \frac{r_{i}}{r_{p}}}{2 \pi T}
$$

where

$s=$ drawdown in the observation

$r_{p}=$ distance from the pumped well to the observation well

$r_{i}=$ distance from the image well to the observation well

$T=$ transmissibility

$Q=$ pumping rate.

This equation may be expressed in terms of the distance (2a) between the real and the image well as

$$
s=\frac{2.30 Q \log \frac{\sqrt{4 a^{2}+r_{p}{ }^{2}-4 a r_{p} \cos \theta}}{r_{p}}}{2 \pi T} .
$$

where $\theta$ is the angle between a line connecting the pumped and image wells and a line connecting the pumped well and the observation well.

\section{DISTANCE TO LINE SOURCE}

If equation 2 is written for any two observation wells (distant from the pumped well $r_{1}$ and $r_{2}$ ) and one equation is divided by the other, we obtain

$$
\frac{s_{1}}{s_{2}}=\frac{\log \frac{\sqrt{4 a^{2}+r_{1}^{2}-4 a r_{1} \cos \theta_{1}}}{r_{1}}}{\log \frac{\sqrt{4 a^{2}+r_{2}^{2}-4 a r_{2} \cos \theta_{2}}}{r_{2}}} .
$$

If $\Theta, s$, and $r$ are known for two points in the well field, the equation can be solved for $a$, the distance to the line source. In practice, the line source is assumed parallel to the river, and $\theta$ is readily obtained.

If observation wells are placed on a line perpendicular to the river on the river side of the pumped well, $\theta=0^{\circ}$, and

$$
\frac{s_{1}}{s_{2}}=\frac{\log \frac{2 a-r_{1}}{r_{1}}}{\log \frac{2 a-r_{2}}{r_{2}}} .
$$

If on the land line, $\theta=180^{\circ}$, and

$$
\frac{s_{1}}{s_{2}}=\frac{\log \frac{2 a+r_{1}}{r_{1}}}{\log \frac{2 a+r_{2}}{r_{2}}}
$$


If placed on a line through the pumped well and parallel to the river, $\theta=90^{\circ}$ or $270^{\circ}$, and

$$
\frac{s_{1}}{s_{2}}=\frac{\log \frac{\sqrt{4 a^{2}+r_{1}^{2}}}{r_{1}}}{\log \frac{\sqrt{4 a^{2}+r_{2}^{2}}}{r_{2}}} .
$$

If various pairs of wells are used and values of $a$ are consistent, the assumed conditions are verified. However, if values of $a$ differ, the transmissibility is not uniform.

Kazmann has proposed two methods of determining values of $a$. One is the nonequilibrium method of matching curves (Kazmann, 1946, p. 854). This method was tried by the writer on two tests, with discouraging results. The observed curves broke sharply and then reversed on the log-log plot. It is thought that large screen corrections in the observation wells, effect of a section of lower transmissibility at the river's edge, or slow drainage in the aquifer make this method impractical in many places.

The second method is extension of a profile on the river side (Kazmann, 1948b, p. 85). This method gives full weight to observations on the river line of wells. Results will agree with those obtained from equation (4) when applied to the river line of wells. This method is adequate and simple in application in the case where transmissibility is uniform, but might give poor results where transmissibility is not uniform.

TRANSMISSIBILITY

Equation (2) may be written for $T$, dropping the subscript $p$ in order to generalize the equation,

$$
T=\frac{2.30 Q \log \frac{\sqrt{4 a^{2}+r^{2}-4 a r \cos \theta}}{r}}{2 \pi s} .
$$

For specific cases, if the observation well is on the river line, $\theta=0$;

$$
T=\frac{2.30 Q \log \frac{2 a-r}{r}}{2 \pi s}
$$

for the land line, $\theta=180^{\circ}$,

$$
T=\frac{2.30 Q \log \frac{2 a+r}{r}}{2 \pi s}
$$


and for a line parallel to the source, $\theta=90^{\circ}$ or $270^{\circ}$,

$$
T=\frac{2.30 Q \log \frac{\sqrt{4 a^{2}+r^{2}}}{r}}{2 \pi s} .
$$

If $a$ is known, transmissibility may be computed on the basis of the drawdown at each observation well. Values of $T$ thus obtained are "apparent" and are based on the assumption of normal flow distribution; however, if the transmissibilities are quite different in various parts of the aquifer, the discharge distribution will be affected materially, and the computed values of $T$ will be in error.

An average solution for transmissibility based on all wells may be obtained by plotting $s$ against

$$
\log \frac{\sqrt{4 a^{2}+r^{2}-4 a r \cos \theta}}{r} .
$$

The use of semilog paper is convenient. A straight line through $s=0$,

$$
\frac{\sqrt{4 a^{2}+r^{2}-4 a r \cos \theta}}{r}=1
$$

on the log scale, averaging all points, defines the average value of

$$
\frac{\log \frac{\sqrt{4 a^{2}+r^{2}-4 a r \cos \theta}}{r}}{s} .
$$

For convenience, the slope of this line can be picked from the curve at the 10 intercept on the semilog plot where

$$
\frac{\sqrt{4 a^{2}+r^{2}-4 a r \cos \theta}}{r}=10
$$

or

$$
\log \frac{\sqrt{4 a+r-4 a r \cos \theta}}{r}=1 .
$$

Equation (7) then simplifies to

$$
T=\frac{2.30 Q}{2 \pi s_{(10 \text { 1ntereept })}} .
$$

An average solution for $T$, if used for design purposes, could be misleading where transmissibilities are low on the riverward side and high on the land side. For safe design a minimum value of $T$ can be obtained by constructing a line on the semilog plot through $s=0$,

$$
\frac{\sqrt{4 a^{2}+r^{2}-4 a r \cos \theta}}{r}=1,
$$


and enveloping all plotted points, instead of using the average of the 'plotted points.

\section{DESIGN OF WELL}

After $a$ and $T$ have been determined, the yield of a production well or collector can be computed by use of equation (7), if it is modified to allow for the eccentricity caused by gradients being steeper on the riverward side than on the landward side. Lines of equal drawdown in the cone of depression are nonconcentric circles with their radii on a line normal to the source. When a well of effective radius, $r_{w}$, is pumped, the drawdown is the same at all points on the radius; or in effect, the well falls on one of the circles of equal drawdown and its center does not coincide with the theoretical point sump for the system, but is located landward from the theoretical sump. Let $a$ be the distance from the theoretical sump to the line source and $x$ be the distance from the physical center of the well (for a collector, the effective center of the lateral system) to the line source. The distance, $x-a$, which is designated eccentricity, $e$, can be determined from equations (8) and (9). Select points on the riverward and landward profiles a distance $r_{w}$ from the well center. Because the drawdowns at these points are equal, the log term of equation (8) equals the log term of equation (9). In equation (8), $r=r_{v}-e$; in equation (9), $r=r_{w}+e$. The equation reduces to

$$
e=x-\sqrt{x^{2}-r_{w}^{2}} .
$$

It can be seen that $e$ will approach zero as $r_{w}$ becomes small. For small-radius wells, $x$ is essentially equal to $a$, and equation (7) may be rewritten

$$
Q=\frac{2 \pi T s}{2.30 \log \frac{2 a}{r_{w}}}=\frac{2 \pi T s}{2.30 \log \frac{2 x}{r_{w}}} .
$$

Where the effective radius of the well is large,

$$
Q=\frac{2 \pi T s}{2.30 \log \frac{x+{\sqrt{x^{2}-r_{w}^{2}}}^{2}}{r_{w}}} .
$$

In the use of equations (13) and (14), if the location and radius of the well are known, $Q$ can be computed; if a given value of $Q$ is desired, it can be obtained by moving the well (varying $x$ ) or by changing the radius of the well.

In these equations the term $s$ is not the total drawdown in the well but the drawdown in the aquifer outside the well. Loss of head through the well screen, or "well losses," must be taken into account. 
Total drawdown in well, $s_{w}$, is equal to screen loss $s_{s}$ plus aquifer loss $s$, or

$$
s=s_{w}-s_{s} .
$$

Jacob (1947, p. 1047) has developed a method of determining $s$ and $s_{s}$. He gives the equation

$$
s_{w}=B Q+C Q^{2},
$$

where $B Q=s$ and $C Q^{2}=s_{s}$.

Equation (13) is then modified,

$$
Q=\frac{2 \pi T\left(s_{w}-C Q^{2}\right)}{2.30 \log \frac{2 x}{r_{w}}} .
$$

For very large wells or collectors, equation (14) may or may not require modification. For a collector with several hundred feet of screen, the $C ?^{2}$ term will be very small and may be neglected.

If the term $C$ is evaluated during a multiple-step drawdown test for a given well with a screen designed to fit the aquifer, it is possible to estimate the value of $C$ for otber wells screened with the same length screen and the same size slot, but having different radii. The term $C Q^{2}$ was written on the basis that the head loss would vary as the square of the velocity $(v)$ and that for a given well the screen area $(A)$ is constant. The term may be written $K V^{2}=K ?^{2} / A^{2}=C Q^{2}$, from which $C=K / A^{2}$. $C$ varies inversely as $A^{2}$, and for the case under consideration, $C$ varies inversely as $r^{2}$.

Equation (17) is modified,

$$
Q=\frac{2 \pi T\left[s_{w}-C Q^{2}\left(\frac{r_{t}}{r_{d}}\right)^{2}\right]}{2.30 \log \frac{2 x}{r_{w}}},
$$

where

$s_{w}=$ available head

$C=$ screen-loss constant from step test

$r_{t}=$ radius of test well

$\mathrm{r}_{d}=$ radius of design well

$r_{w}=$ effective radius of design well

$x=a=$ distance to line source.

Finally, the fact that dewatering of the aquifer may occur should be introduced. Modified equations are:

For well of large radius,

$$
Q=\frac{\pi \frac{\left(m_{1}+m_{2}\right)}{m_{1}} T s_{w}}{2.30 \log \frac{x+\sqrt{x^{2}-r_{w}^{2}}}{r_{w}}} ;
$$


for well of small radius,

$$
Q=\frac{\pi \frac{\left(m_{1}+m_{2}\right)}{m_{1}} T\left[s_{w}-C Q^{2}\left(\frac{r_{t}}{r_{d}}\right)^{2}\right]}{2.30 \log \frac{2 x}{r_{w}}} ;
$$

where $m_{1}$ is the average thickness of aquifer prior to pumping and $m_{2}$ the thickness of aquifer at the pumped well during pumping.

The discharge computed from these equations will be for the temperature conditions prevailing during the test used to determine transmissibility. It can be corrected to other temperature conditions by using the appropriate correction for change in viscosity with temperature.

\section{RIVER INFILTRATION}

\section{PUMPING-TEST DATA AND PROCEDURE}

It is generally recognized that the use of pumping tests is a way of arriving at definite conclusions as to whether infiltration supplies are available and to what extent. Studies of water-level profiles and comparisons of water-level and river-level fluctuations may definitely establish that infiltration supplies cannot be developed in certain areas, but such studies generally cannot, in themselves, be used to establish definitely that a connection exists between the aquifer and the river and cannot furnish enough information for definition of the hydrologic constants of the aquifer.

Preliminary studies of the water levels in the area indicated that the conditions were not unfavorable for development of infiltration supplies. In comparing fluctuations of the river and water level in different observation wells, it was concluded that conditions were nearly the same in different segments of the reach of the river under study. As the hydrologic conditions appeared to be similar throughout the reach, the site for the pumping test was selected on the basis of practical considerations; that is, where permission to drill could be obtained and where electric power was available to operate the pump used in making the test. The site selected was 300 feet downstream from the city of Louisville river pumping plant (pl. 2).

A plan of the pumping-test area and location of observation wells is shown in figure 6 . Wells were laid out in the form of a cross with the pumped well at the center. Three of the riverward line of wells were in the Ohio River. These wells were cased with $6 \%_{2}^{\prime}$-inch steel casing slotted near the bottom and driven to bedrock. The wells on land were cased with 4-inch steel casing and screened with 2 feet of No. 10 (0.010 inch) or No. 30 (0.030 inch) slot screen near the bottom of the aquifer, depending on the texture of the sand and gravel penetrated. Data for these wells are shown in table 2. 


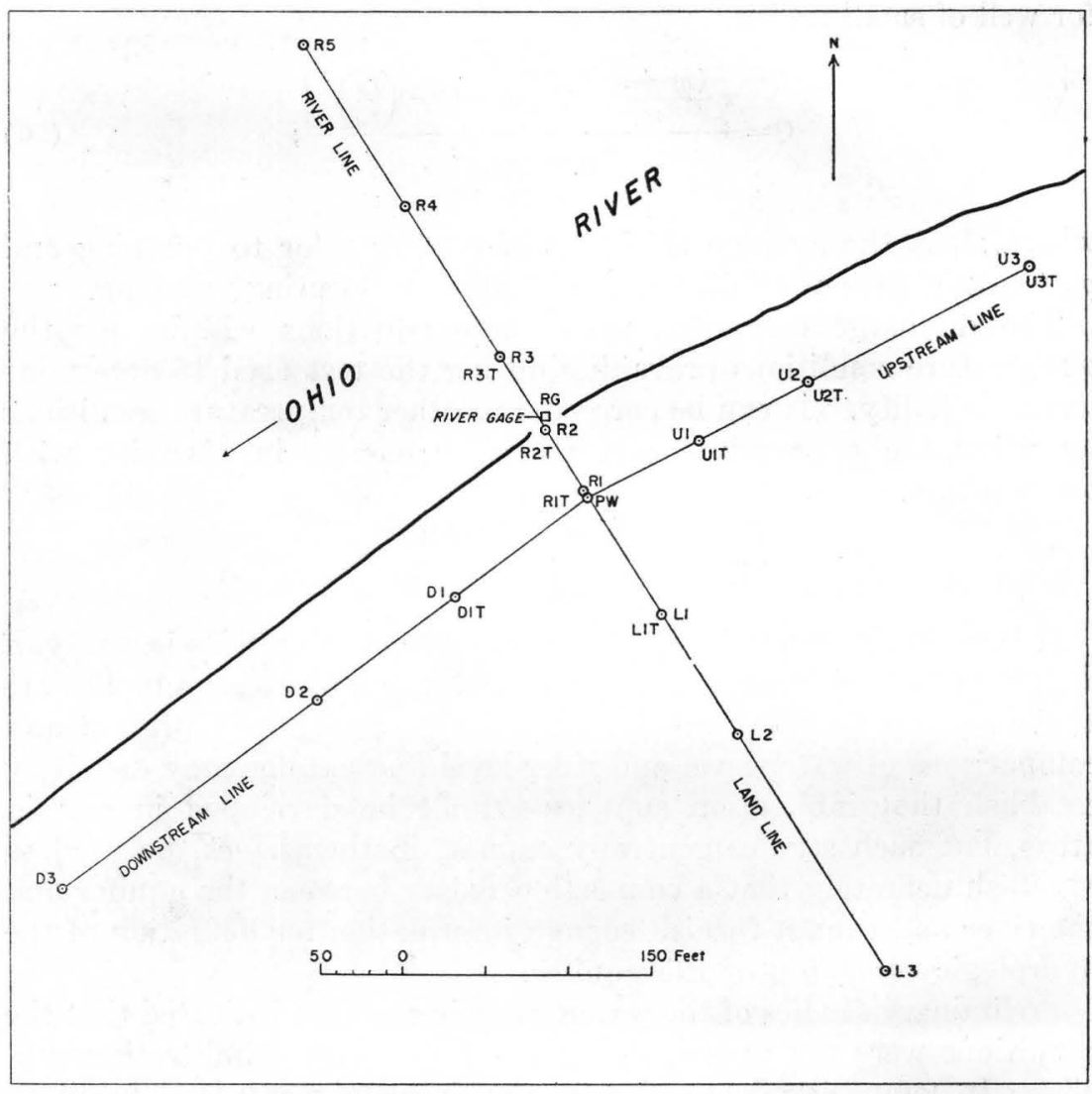

Figure 6.-Map of northeastern section of Louisville area showing location of wells in pumping-test area.

The wells in each line were numbered, beginning near the pumped well. The lines were designated, $U$ for upstream, D for downstream, $\mathrm{L}$ for the landward side of the pumped well, and $\mathrm{R}$ for the riverward side. In addition to the larger observation wells, seven 11/4-inch driven wells were installed, their screens being in the upper part of the aquifer near the top. These wells were given the same symbols as those screened at the bottom except for the addition of the letter T. For example, well R3 is the third well from the pumped well on the riverward line and is screened at the bottom of the aquifer; well $\mathrm{R} 3 \mathrm{~T}$ is at the same location but is screened near the top of the aquifer. A 4-inch uncased hole was bored by auger at U3T. The locations of the observation-well screens are shown on the sections on figure 7 .

The bedrock at the test site is relatively flat and at an average elevation of about 335 feet above mean sea level (fig. 7). The glacialoutwash deposits penetrated in the test area seem to be in continuous 


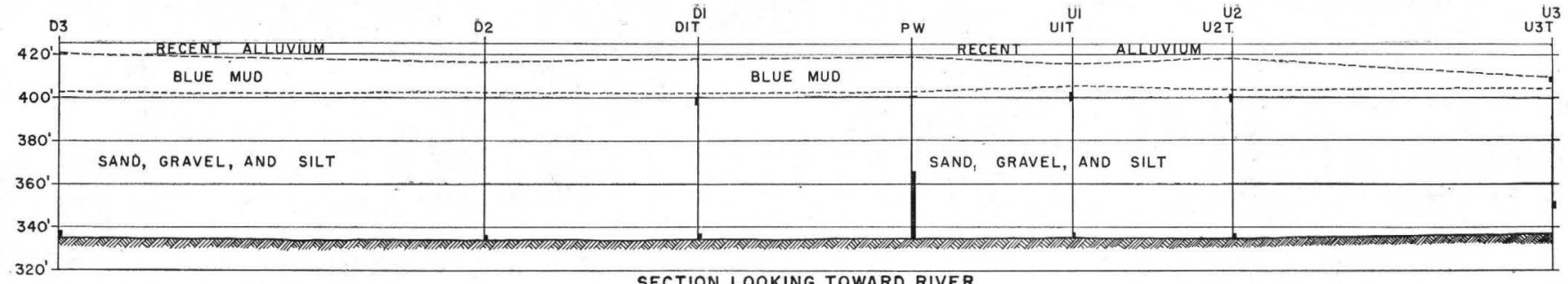

SECTION LOOKING TOWARD RIVER

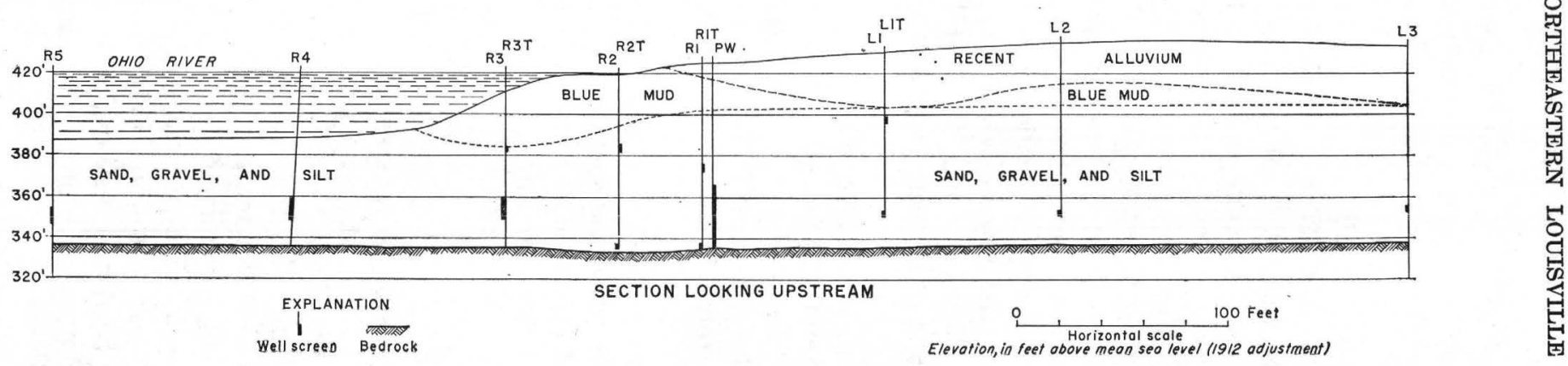

FIGURE 7.-Sections of pumping-test area, northeastern section of Louisville area. 
beds; the bottom 5 feet, elevation $335-340$ feet, is a mixture of very fine sand and silt; above this, and ranging from 7 to 15 feet in thickness, is a bed of coarse gravel mixed with cobbles, a few small boulders, and medium sand; above the gravel is a relatively thick bed of medium sand mixed with small amounts of gravel and silt. The medium sand is capped by 20 to 30 feet of blue-gray mud and Recent alluvium. As stated previously, it should be noted that the clay cap dips riverward at the water's edge and tapers to a feather edge about 100 feet beyond the water's edge. The thickness of the aquifer between the bedrock and the clay averages about 70 feet except in the zone where it is reduced to about 50 feet by this clay lip. The water levels in the observation wells fluctuate at an average elevation of 419.5 feet above mean sea level (1912 adjustment), the normal pool elevation of the river. However, detailed analysis of river and well fluctuations showed that the ground-water level normally was about 0.1 foot lower than the river level. The total available head from river level to rock is about 85 feet, from 419.5 to about 335 feet above mean sea level.

The pumped well (No. PW), cased with 12-inch steel casing, was constructed with 30 feet of welded steel screen at the bottom. The screen was designed to pass slightly more than 60 percent of the material; the slot sizes used were No. 20 (0.020 inch) for the top 10 feet and bottom 5 feet and No. 100 (0.100 inch) slots for the remaining 15 feet.

A horizontal 8-inch discharge line 17.2 feet long was provided. A 6 -inch orifice plate was installed on the end of the 8-inch line. Two feet back of the orifice a vertical manometer tube was installed with a gage plate graduated every 0.02 foot. Readings were made to the nearest 0.01 foot. Levels were run to the discharge pipe and the gage plate periodically during the test so that orifice readings could be corrected for settlement. The orifice was rated during a previous test by means of 300-gallon tank and a stopwatch. It was found that the discharge at a given reading was about 5 percent less than that given by the standard rating table for a 6 -inch orifice. The rating used may be expressed by the equation, $Q$ (gpm.) $=514 h^{1 / 2}$, where $h$ is the manometer reading in feet. The entire rating may be in error by several percent, but the error is probably consistent and does not affect the accuracy of corrections for changes in pumping rate, which are based on differences. Thus, only the refinement of readings need be considered. In the range used, an error of 0.01 foot in manometer reading represents an error of $1 \mathrm{gpm}$ in 1,100, or about 0.1 percent.

The 12-inch well was pumped for 14 days (1:00 p. m. on October 22 to $12: 13 \mathrm{p} . \mathrm{m}$. on November 5,1946$)$ at a constant setting of the valve: 
on the discharge line. The discharge as determined from orifice readings averaged 1,107 gallons per minute and varied as shown on plate 8; it increased slightly during the test. The increase was caused in part by a reduction in pumping lift resulting from a rise in water level in the well. Also, a part of the increase may have been due to the effects of increased temperature in the aquifer or to rearrangement of the sand and gravel particles around the screenequivalent to additional development of the well-during the test.

On October 21, 1946, prior to the 14-day test, a 5-hour multiple-step drawdown test was made. In this test the 12-inch well was pumped for an hour at each of five increasing rates of discharge.

Automatic float-type recorders were maintained on 18 of the observation wells screened near the bottom of the aquifer during the test and for several months following the test. The time scales used were 1.2 inches $=1$ day, 4.8 inches $=1$ day, 9.6 inches $=1$ day, 9.6 inches $=8$ hours, 9.6 inches $=90$ minutes, depending on the location. The water-level scales were selected according to the magnitude of drawdown expected. Those used were 1:10, 1:5, and 1:1. Waterlevel measurements were made periodically by steel tape in the 1/4-inch wells penetrating the upper part of the aquifer and in the pumped well. Observed water levels are shown on plates 8 to 15 . Records obtained by automatic instrument are shown by solid lines, those based on tape readings by dashed lines.

An automatic float-type recording gage was installed to obtain a record of river-level fluctuations (pl. 10). The river is controlled by lock and dam 41 several miles downstream, at Louisville. Regulation of the movable dam maintains the river elevation within about 1 foot of elevation 419.5 feet most of the time. Occasionally (on the average about once a year), usually in the spring, floods exceed the capacity of the openings in the dam and the stage will rise. The maximum flood recorded at this site was 461.7 feet above mean sea level on January 27, 1937 (1907 adjustment). The operation of the movable dam, lockage of boats, and operation of the power plant at the dam, cause the water level of the pool to rise or fall with each operation.

Readings of barometric pressure were obtained from the Louisville office of the U. S. Weather Bureau. A graph of barometric pressure is shown on plate 16 .

Temperatures of river water and water from the pumping well were measured periodically. In addition, temperatures were observed at 5 -foot intervals of depth in observation wells by means of an electric resistance thermometer. These data are shown on plates 17, 18 and figure 8 .

Temperature readings at various depths in observation wells in the river checked with those obtained at corresponding depths in the river. 


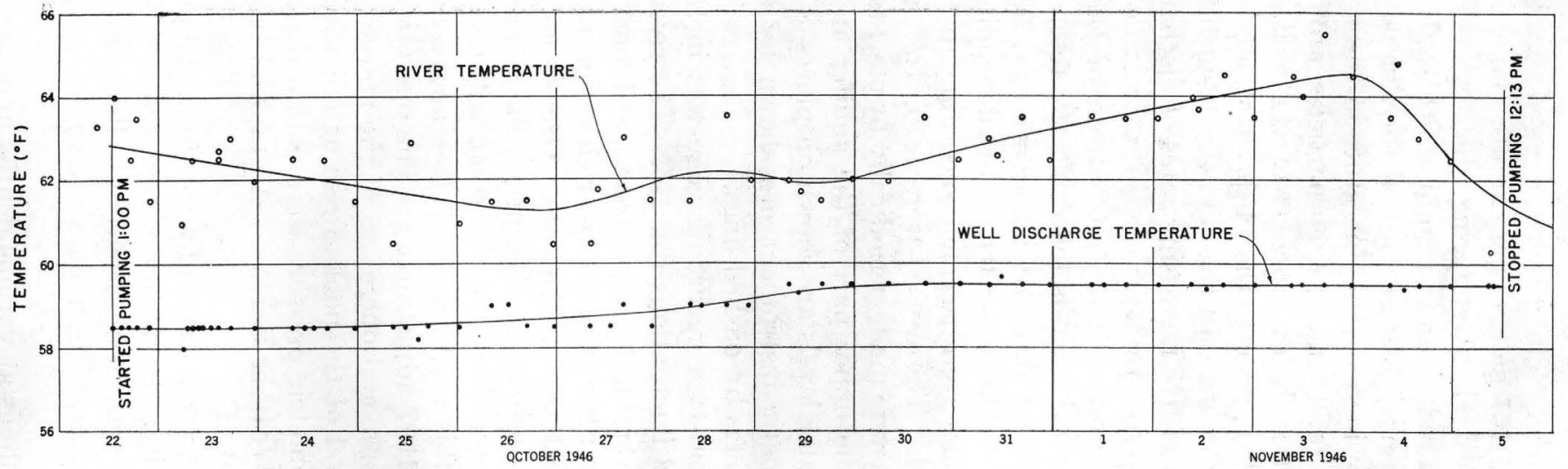

FigURE 8.-Graph showing comparison of temperature of Ohio River and water from pumped well during test. 
From this it was concluded that the temperature of the water in the well at any point represented the temperature of the aquifer outside the casing. No evidence of circulation or mixing of warm and cold water was noted within the well so long as the column of water was not disturbed. Temperatures were taken progressively from the top to the bottom to avoid disturbing the water column with the electric cable of the instrument.

Water samples were collected daily from the pumped well. Chemical analyses were made by the Louisville Water Co. and by the U. S. Geological Survey. Results of the analyses are shown in table 6 . Results of complete analyses of samples taken at the beginning and end of the test are shown in table 5 .

Two samples, taken October 24 and 29, were analyzed by the State Department of Health of Kentucky and were found to be free from sewage or other fecal pollution.

\section{EVIDENCE OF CONNECTION BETWEEN AQUIFER AND RIVER}

The basic data were examined for indication of a connection between the river and the aquifer. Two approaches were considered:

\section{CHEMICAL ANALYSES}

Figure 9 shows a comparison of the sulfate content of river water and water from the pumped well during the period of the test. This comparison appears to indicate that river water is reaching the well. However, examination of the analyses made at each well prior to the test (table 3 and fig. 10) shows that the sulfate content of the ground water is quite erratic in distribution. The area near the pumped well contained water high in sulfates, whereas areas away from the pumped well had less sulfate content than the river water. Assuming no connection with the river, circles have been drawn showing the cylinder face which would reach the well at various times after the start of pumping. Inspection shows that the sulfate content should drop as in figure 9 even if no river connection existed. Study of the other chemical components gives no confirmation of recharge. It is apparent that this method is not applicable because of the short duration of the test.

\section{TEMPERATURE}

Plates 17 and 18 are sections showing temperature distribution as measured periodically during the test. Plate 17 , of the section perpendicular to the river, shows that there was warm water beneath the river bed at the beginning of the test. This warm water must have traveled from the river into the underlying aquifer during the summer months preceding the test. As pumping progressed, the warm water moved downward and landward toward the well screen. 
TABLE 6.-Chemical analyses, in parts per million, of water from pumped well and range in chemical content of Ohio River water during infiltration pumping test, 1946

[Analysts: a, City of Louisville; b, U. S. Geological Survey]

\begin{tabular}{|c|c|c|c|c|c|c|c|c|c|c|c|c|}
\hline \multicolumn{2}{|c|}{ Sample collected } & \multirow{2}{*}{$\begin{array}{c}\text { Temper- } \\
\text { ature } \\
\left({ }^{\circ} \mathrm{F}\right)\end{array}$} & \multirow{2}{*}{$\mathrm{pH}$} & \multirow{2}{*}{$\begin{array}{l}\text { Iron } \\
(\mathrm{Fe})\end{array}$} & \multirow{2}{*}{$\begin{array}{c}\text { Bicar- } \\
\text { bonate } \\
\left(\mathrm{HCO}_{3}\right)\end{array}$} & \multirow{2}{*}{$\begin{array}{c}\text { Sulfate } \\
\left(\mathrm{SO}_{4}\right)\end{array}$} & \multirow{2}{*}{$\begin{array}{c}\text { Chloride } \\
\text { (C1) }\end{array}$} & \multirow{2}{*}{$\begin{array}{l}\text { Nitrate } \\
\left(\mathrm{NO}_{3}\right)\end{array}$} & \multirow{2}{*}{$\begin{array}{l}\text { Carbon } \\
\text { dioxide } \\
\left(\mathrm{CO}_{2}\right)\end{array}$} & \multirow{2}{*}{$\begin{array}{c}\text { Dissolved } \\
\text { solids }\end{array}$} & \multirow{2}{*}{$\begin{array}{c}\text { Total } \\
\text { hardness } \\
\text { as } \mathrm{CaCO}_{3}\end{array}$} & \multirow{2}{*}{ Analysts } \\
\hline Date & Time & & & & & & & & & & & \\
\hline
\end{tabular}

Analyses of water from pumped well

\begin{tabular}{|c|c|c|c|c|c|c|c|c|c|c|c|c|}
\hline & $\begin{array}{l}2: 45 \text { p. m } \\
2: 45 \text { p. m }\end{array}$ & 56.5 & $\begin{array}{l}7.6 \\
7.1\end{array}$ & $\begin{array}{r}2.1 \\
- \\
-2\end{array}$ & $\begin{array}{l}376 \\
389\end{array}$ & $\begin{array}{r}186 \\
-18 \\
-1\end{array}$ & 16 & $\begin{array}{c}0.3 \\
\end{array}$ & 32 & $-\cdots$ & $\begin{array}{l}506 \\
510\end{array}$ & $\begin{array}{l}\mathrm{b} \\
\mathrm{a}\end{array}$ \\
\hline $\begin{array}{l}23 \\
24\end{array}$ & $\begin{array}{l}9: 10 \text { a. } m-\ldots . \\
1: 35 \text { p. } \mathrm{m}\end{array}$ & $\begin{array}{l}57 \\
57\end{array}$ & & $\begin{array}{l}1.4 \\
1.2\end{array}$ & $\begin{array}{l}383 \\
370\end{array}$ & 148 & 16 & .0 & 23 & & $\begin{array}{l}480 \\
428\end{array}$ & $\mathrm{a}$ \\
\hline 25 & $11: 55$ a. $\mathrm{m}$ & 57 & 7.3 & 1.4 & 380 & & & & 21 & & 500 & a \\
\hline 26 & $11: 45$ a. $\mathrm{m}$ & 57 & & 1.2 & $\begin{array}{l}366 \\
378\end{array}$ & 134 & 15 & .0 & & 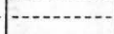 & 435 & $\mathrm{~b}$ \\
\hline $\begin{array}{l}27 \\
28\end{array}$ & $11: 05$ a. $\mathrm{m}$ & $\begin{array}{l}57 \\
57\end{array}$ & 7.3 & $\begin{array}{l}1.6 \\
1.3\end{array}$ & $\begin{array}{l}378 \\
364\end{array}$ & 123 & 15 & .0 & 16 & - & 470 & $\mathrm{a}$ \\
\hline 29 & $11: 15$ a. $\mathrm{m}$ & 58 & 7.3 & 1.4 & 372 & 120 & 10 & .0 & 19 & & 440 & a \\
\hline 30 & $5: 35 \mathrm{p}, \mathrm{m}$ & 58 & & 1.1 & 354 & 115 & 16 & .0 & & $-\ldots$ & 390 & $\mathrm{~b}$ \\
\hline & $10: 38$ a. $\mathrm{m}$ & 58 & 7.2 & 1.4 & 368 & & & & 19 & -........- & 440 & $\mathrm{a}$ \\
\hline Nov. $\frac{1}{3}$ & $12: 00 \mathrm{~m}$ & $\begin{array}{l}58 \\
58\end{array}$ & -1 & 1.1 & 352 & 111 & 16 & .0 & $-\cdots-$ & 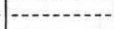 & 435 & $\mathrm{~b}$ \\
\hline 4 & 11:00 a. m & 58 & 7.3 & $\begin{array}{l}1.0 \\
1.3\end{array}$ & $\begin{array}{l}352 \\
358\end{array}$ & 108 & 10 & .0 & 19 & & $\begin{array}{l}420 \\
410\end{array}$ & $\begin{array}{c}\mathrm{D} \\
\mathrm{a}\end{array}$ \\
\hline 5 & $11: 43$ a. $\mathrm{m}-1$ & 58 & 7.7 & 1.9 & 343 & 107 & 16 & .1 & & 474 & 402 & $\mathrm{~b}$ \\
\hline & $11: 43$ a. m.......... & 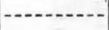 & 7.3 & & 358 & & & & 13 & $--\cdot$ & 390 & a \\
\hline \multicolumn{13}{|c|}{ Range in chemical content of Ohio River water } \\
\hline Maximum & (n) & \multirow{2}{*}{$\begin{array}{l}62 \\
60\end{array}$} & \multirow{2}{*}{$\begin{array}{l}7.7 \\
7.3\end{array}$} & & \multirow{2}{*}{$\begin{array}{r}106 \\
72\end{array}$} & \multirow{2}{*}{$\begin{array}{r}131 \\
81\end{array}$} & & & & & \multirow{2}{*}{$\begin{array}{l}196 \\
166\end{array}$} & \multirow{2}{*}{$\begin{array}{l}\mathrm{a} \\
\mathrm{a}\end{array}$} \\
\hline Minimum & 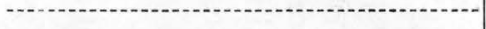 & & & & & & & & & & & \\
\hline
\end{tabular}

Note: Well number 42-16-37 (PW) was pumped 5 hours on October 21, 1946, and at 1,107 gallons per minute from 1:00 p. m., October 22, 1946, to 12:13 p. m., November 5, 1946. 
Each contour of temperature progressed to the screen. (See also fig. 8 , showing the rise in temperature of the water pumped during the test.) It is evident that the flow of water was downward from the river and then toward the well. It is also apparent that the area of highest permeability is in the lower part of the aquifer, as the movement was most pronounced there.

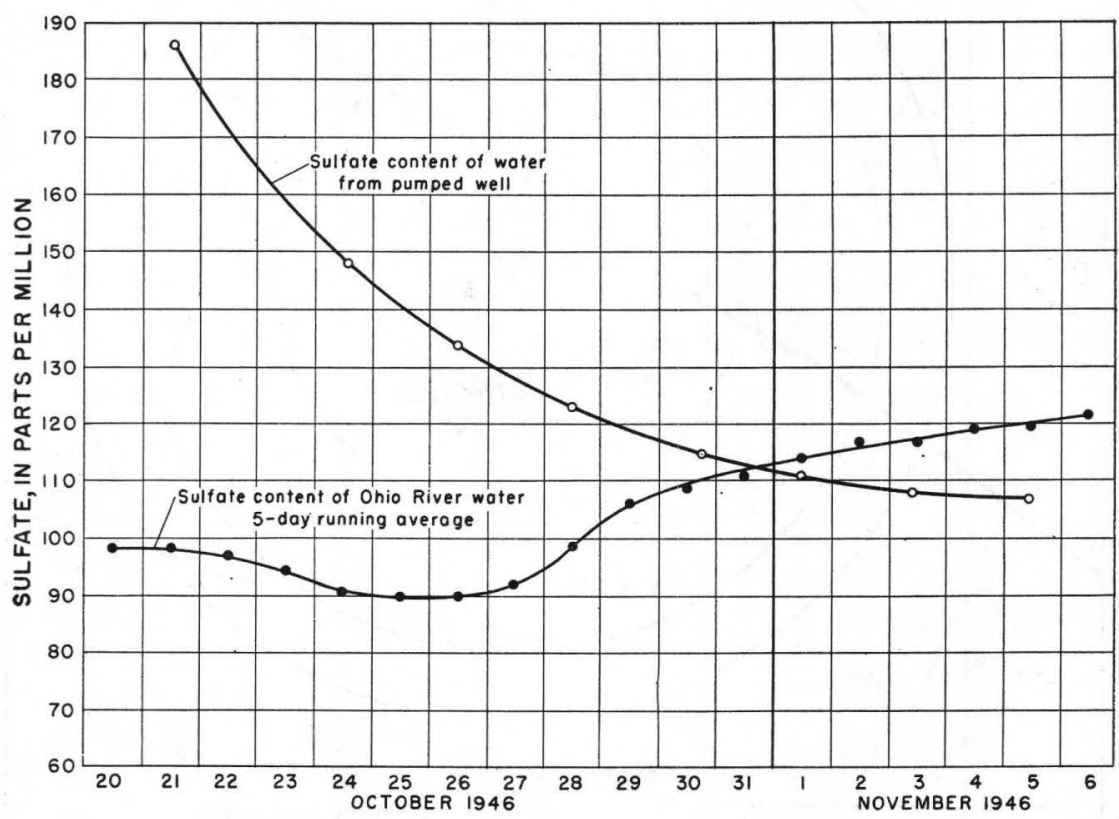

Figure 9.-Curves of sulfate content of Ohio River and well water during pumping test.

Plate 17 also confirms the existence of upward flow from the bedrock near well R2. Water at the bottom of this well became colder while water in the surrounding area became warmer (October 23 to 29); however, the upward flow must be small in comparison to the flow of water in the aquifer. If this flow had been larger, the temperature pattern would have been considerably different.

Another point of interest in plate 17 is the reduction in temperature near the top of the aquifer at R2 (October 23 to 25). This indicates that the clay lip forming a partial barrier caused a distorted flow pattern in this area; water from the part of the aquifer upstream, downstream, or both, was flowing along the barrier, thence downward and landward to the pumped well.

Plate 18, showing temperature distribution in a section parallel to the river, shows the development of higher-temperature cusps near the pumped well as the warm water from under the river flowed to the well. 


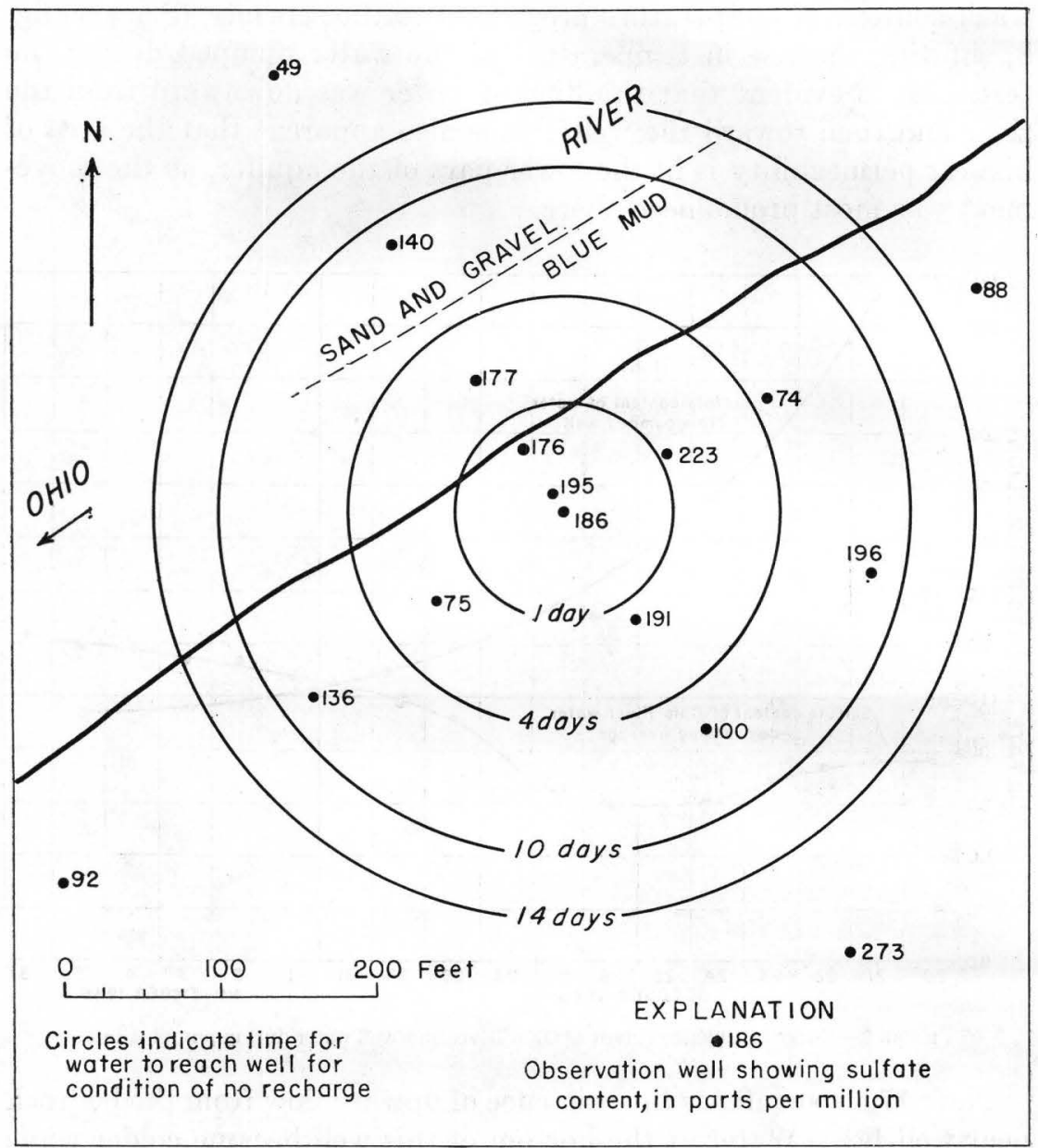

FIG URE 10.-Map of northeastern section of Louisville area showing sulfate in water from observation wells.

These temperature sections are considered positive proof that a connection exists between the river and the aquifer.

\section{DRAWDOWN CORRECTIONS}

All the equations presented in part 2 on the theory of induced infiltration are based on the assumption that pumping has continued until a steady-flow condition has been established. In the application of the equations, the basic data required are (1) the distance from the pumped well to the observation well, (2) the angular location of the observation well in relation to the pumped well, and (3) the observed drawdown in the observation well. 
Accurate values of drawdown $(s)$ must be obtained and corrections applied to convert them to conditions of steady flow, constant river and barometric conditions, and constant pumping rate. Screen-loss corrections in the observation wells must also be considered. The fact that the screen in the pumped well is near the bottom of the aquifer causes the flow lines to be distorted downward in the vicinity of the pumped well. The position of the observation-well screen in the aquifer must also be taken into consideration.

The procedure for correcting drawdowns in one well is outlined as follows:

The problem is: (1) Construct a graph of the water level in the well as it would have been if there had been no pumping, (2) correct the graph of water level observed during the pumping period for screen loss in the observation well, (3) subtract these graphs to obtain the graph of drawdown, and, finally, (4) correct the graph for variations in the pumping rate.

\section{BASE FLOW}

Because the theory is based on steady-flow conditions, the effects of changes in the normal flow in the aquifer must be considered. The initial flow conditions at the test site involves two conditions:

First, the normal condition of flow is from the valley wall toward the river. Study of well records for areas unaffected by pumping shows that the gradient toward the river did not change materially during the test period.

The second condition is the effect of pumping in the downtown area of Louisville, 3 miles southwest of the test site. The cone of depression extends to the river and affects the area on the downstream side of the well pumped in the test. The flow in this area is southwestward toward the center of pumping. Between the well pumped in the test and the valley wall the flow is nearly parallel to the river. Pumping in the downtown area was reduced at the end of September, the close of the air-conditioning season, from an average of 16 million gpd to an average of 9 million gpd. Water-level recovery in the downtown area was only about 0.6 foot during the period of the test. The change in gradient in the 3-mile cone from the pumping-test site to the downtown pumping area was very small, 33.6 feet to 33.0 feet in 3 miles, or about 2 percent. Thus the change in the drawdown at the site of the pumping test would bave been less than 2 percent, the amount ranging from about 0.02 foot at the southwest edge of the zone of influence of the pumping test to zero at the pumped well. Essentially, the effect of the pumping test was superimposed on an aquifer condition of steady nonuniform flow. 


\section{EFFECTS OF RIVER FLUCTUATIONS}

Date from recorders showing fluctuations of river level and of the water level in each well were plotted against time. Comparison of the graphs (pls. 8-15) shows that the aquifer responds to river-level changes, the response being greatest at wells close to the river and least at wells away from the river.

A strict analysis of the effect of river-level changes on water levels could be obtained by use of the equation for the parallel case of heat transfer (McAdams, 1942, p. 38); the equation for heat transfer from a line source to any point in a uniform plate of infinite extent can be expressed in terms of ground-water units as:

$$
\frac{h}{h_{0}}=1-\frac{\mathbb{2}}{\sqrt{\pi}} \int_{0}^{z} e^{-z^{2}} d z,
$$

where

$$
\begin{aligned}
z & =\frac{x}{2 \sqrt{T t / S}} \\
x & =\text { distance from line source to observation point } \\
h_{0} & =\text { change in river level at initial time } \\
t & =\text { time elapsed since change in river level } \\
h & =\text { change in water level at time } t, \text { at observation point } \\
S & =\text { storage coefficient } \\
T & =\text { transmissibility. }
\end{aligned}
$$

Derivation of corrections for river changes by use of this equation would involve a considerable amount of work, as the river level is continually fluctuating; however, the cyclic operation of the power plant at dam 41 and the fact that the dam is regulated within close limits cause the duration of the high and low stages of the river to be quite uniform. A simplified approximation of the river correction can be obtained by assuming that the time lag to any given well will be approximately constant. A factor, called the "river factor," for correcting for river effect at each well was obtained by plotting river changes against corresponding water-level changes. A straight-line relationship was used for the test. It was found that errors introduced by neglecting the time factor were very small. The correction factors for river effect are shown in table 7 . The factors are expressed in feet of change in water level for a 1-foot change in river level.

\section{BAROMETRIC EFFECTS}

Records of barometric pressure, river level, and water level in observation well L4 (1,600 feet from the river) were analyzed by graphical correlation (Ezekiel, 1941) for a period prior to pumping. River corrections were determined as outlined above. The corrections were applied to the water-level graph of the observation well. Fluctuations of the resulting graph were plotted against barometric fluctu- 
ations. A straight-line relationship defined the barometric correction factor. Barometric corrections were computed and applied to the observed water-level graph. A second determination of the river correction was made by plotting fluctuations in the adjusted graph against river fluctuations. This process was repeated until no improvement could be obtained. The barometric factor obtained for well L4 was used as a base for determining corrections at other wells. It was concluded that little or no barometric corrections were applicable in the wells in the river, as the river itself would act as a well and therefore barometric changes would be canceled. If this is true, then wells between the river and well L4 would have a barometric-correction factor equal to that of L4 less the canceling effect of barometric pressure on the river being transmitted landward through the aquifer. This effect would be reduced in the same manner as for river-fluctuation corrections. The expression used for the barometric correction factor is:

$$
F_{b w}=F_{b L 4}\left(1-F_{r w}\right) .
$$

TABLE 7.-Data for observation wells used in pumping test

\begin{tabular}{|c|c|c|c|c|c|c|c|}
\hline \multirow{3}{*}{ Well No. } & \multicolumn{2}{|c|}{ Location } & \multicolumn{2}{|c|}{$\begin{array}{l}\text { Elevation } 1 \text { (feet } \\
\text { above mean sea } \\
\text { level) }\end{array}$} & \multicolumn{3}{|c|}{ Correction factors for- } \\
\hline & Dist & & & & River & $\begin{array}{c}\text { Barometric } \\
\text { pressure }\end{array}$ & Screen loss \\
\hline & $\begin{array}{l}\text { from } \\
\text { pumped } \\
\text { well } \\
\text { (feet) }\end{array}$ & $\begin{array}{c}\theta^{2} \\
\text { (degrees) }\end{array}$ & $\begin{array}{l}\text { Meas- } \\
\text { uring } \\
\text { point }\end{array}$ & $\begin{array}{l}\text { Water } \\
\text { level }\end{array}$ & $\begin{array}{l}\text { Feet per } \\
\text { foot change } \\
\text { in river }\end{array}$ & $\begin{array}{l}\text { Feet per } \\
0.1 \text { inch } \\
\text { of mercury } \\
\text { change }\end{array}$ & $\begin{array}{l}\text { Feet per } \\
\text { foot per } \\
\text { minute of } \\
\text { vertical } \\
\text { velocity }\end{array}$ \\
\hline PW & 0 & 0 & 426.03 & 419.60 & & & \\
\hline R1 & 5 & 0 & 428.81 & 419.65 & 0.59 & 0.0058 & 0.095 \\
\hline R1T $\ldots \ldots$ & 5 & 0 & 426.47 & 419.61 & $\cdots$ & - non & \\
\hline $\begin{array}{l}\text { R2 } \\
\text { R2T }\end{array}$ & $\begin{array}{l}45.8 \\
45.8\end{array}$ & $\begin{array}{l}0 \\
0\end{array}$ & $\begin{array}{l}423.32 \\
421.16\end{array}$ & $\begin{array}{l}419.58 \\
419.58\end{array}$ & .61 & .0055 & .360 \\
\hline R3 & 101 & 0 & 422.37 & 419.60 & .85 & .0021 & .029 \\
\hline R3T & 101 & 0 & 421.33 & 419.54 & $-2-2-1$ & & \\
\hline R4 & 205.6 & 0 & 424.04 & 419.67 & .925 & .0011 & .057 \\
\hline R5 & 324.5 & 0 & 423.66 & 419.69 & 1.00 & .00 & .00 \\
\hline D1 1 T & 100 & 95 & 429.48 & 419.62 & .65 & .0049 & .05 \\
\hline D ${ }_{2}$ & 200.8 & 95 & $\begin{array}{l}420.44 \\
427.79\end{array}$ & $\begin{array}{l}419.03 \\
419.61\end{array}$ & .65 & .0049 & .04 \\
\hline D3 & 397 & 95 & 427.66 & 419.61 & .65 & .0049 & .185 \\
\hline D4 & 3,000 & 95 & 426.65 & 419.25 & .70 & .0043 & \\
\hline L1 1 & 84 & 180 & 434.02 & 419.66 & .60 & .0057 & .042 \\
\hline L1T & & 180 & 430.91 & 419.50 & -7 & 0075 & $\cdots+\cdots$ \\
\hline L3 & $\begin{array}{l}170 \\
339\end{array}$ & $\begin{array}{l}180 \\
180\end{array}$ & $\begin{array}{l}437.93 \\
437.02\end{array}$ & $\begin{array}{l}419.57 \\
419.46\end{array}$ & .47 & $\begin{array}{l}.0075 \\
.0092\end{array}$ & $\begin{array}{l}.57 \\
.22\end{array}$ \\
\hline L4 & 1,600 & 196.5 & 436.84 & 419.35 & .085 & .0130 & $\cdot 22$ \\
\hline L5 & 2,700 & 194 & 432.70 & 419.39 & .01 & .0141 & - n \\
\hline WC5 & 200 & 227 & 437.90 & 419.52 & .50 & .0071 & \\
\hline $\mathrm{U} 1$ & 75 & 265.5 & 427.94 & 419.58 & .65 & .0049 & .33 \\
\hline U1T & 75 & 265.5 & 426.28 & 419.53 & 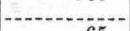 & $-1.2-1$ & 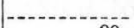 \\
\hline $\mathrm{U} 2 \ldots$ & 150 & 265.5 & 428.81 & 419.62 & .65 & .0049 & .90 \\
\hline U2T & $\begin{array}{l}150 \\
300\end{array}$ & $\begin{array}{l}265.5 \\
265.5\end{array}$ & $\begin{array}{l}426.30 \\
428.97\end{array}$ & $\begin{array}{l}419.56 \\
419.57\end{array}$ & 70 & 0043 & $08 \overline{5}$ \\
\hline U3T & 300 & 265.5 & 424.50 & 421.60 & & & \\
\hline River gage & 50 & 0 & 423.92 & 419.72 & - & 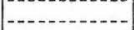 & 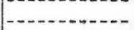 \\
\hline
\end{tabular}

1 At start of pumping test, 1:00 p. m., October 22, 1946.

2 Location angle measured counterclockwise from river line of wells. 
At any well $\mathrm{W}$ the barometric factor equals the barometric effect at the well L4 times the quantity 1 minus the river factor for well W. Inasmuch as there is river effect at $\mathrm{L} 4$, the barometric factor $(0.0130$ foot change in water level per 0.1 inch change of mercury) determined for this well by statistical analysis includes the barometric effect transmitted from the river. Applying equation (22) to well L4 using 0.0130 for the barometric factor and 0.085 for the river factor, the barometric effect $\left(\mathrm{F}_{\mathrm{bL} 4}\right)$ is found to be 0.0142 . This figure was used in the equation to determine the barometric-correction factors which are expressed in feet correction in water level per 0.1 inch of mercury change and are shown in table 7 .

A synthetic record of the water level in an observation well if pumping had not occurred can be built up as follows:

Using a vertical scale of distance below measuring point and a horizontal scale of time, draw a line to represent the effects of changes of flow in the aquifer. In this test, where conditions of nearly steady flow existed, the line will be horizontal and will pass through the observed distance below measuring point at the beginning of the period of pumping. Determine the effects of river-level changes during the test on the water level in the well; apply the river corrections to the steady-flow curve. Determine the barometric corrections and add or subtract from the curve of base-flow and river corrections. The resulting graph of water levels for a condition of no pumping can be checked by extending it beyond the period of recovery following the pumping test. If the computed graph checks the observed graph, it can be inferred that the corrections are reasonably accurate.

\section{SCREEN LOSS IN OBSERVATION WELLS}

Immediately after pumping commences, the water level in the area of the test declines rapidly. The rate of decline is large during the first few minutes and then becomes progressively smaller. During the time of rapid decline, water must leave the observation wells. Flow through the observation-well screen requires a loss of head. In order to maintain a head, the water level in the well must be higher than that of the aquifer. If determination of transmissibility is attempted by the time-drawndown method, corrections for the lag in water-level decline must be made.

Corrections can be derived, based on the rate of discharge of the observation well or, more simply, based on the relation of the vertical velocity in the observation well and the corresponding loss of head needed to maintain that rate of discharge. Water was poured into the observation well; the water level was measured every few seconds as the water ran out. A curve was drawn of vertical velocity in the well against difference between the water level in the well and the 
water level measured prior to adding the water. For the pumping test vertical velocities were computed for short time intervals. From the screen rating corresponding values of head loss were obtained. Corrected water levels were obtained by subtracting screen loss from observed water levels. The method is expected to be reasonably accurate in cases where the range of head used in obtaining the screen rating covers the range observed during the test. The screen ratings obtained for the wells in this test were straight-line relationships, but in some instances in the pumping test they had to be extended beyond the range observed in obtaining the screen rating. A large extension - that is, to high rates of discharge - is risky because the flow may change from laminar to turbulent, when an entirely different relationship would be required. Screen-correction factors are listed in table 7, and are expressed as feet correction in water level per foot per minute of vertical velocity.

\section{ADJUSTMENT FOR CHANGES IN PUMPING RATE}

A time-drawdown curve was obtained by subtracting the observed water-level graph (corrected for screen loss) from the synthetic waterlevel record for a condition of no pumping. This curve reflects the drawdown resulting from pumping. Orifice records of discharge (pl. 8) shows that pumpage decreased, then increased during the test. An average discharge of $1,107 \mathrm{gpm}$ was used in the computations. Drawdowns were adjusted to a base of $1,107 \mathrm{gpm}$, using for each point an inverse ratio of observed discharge to $1,107 \mathrm{gpm}$ as a factor. This method is approximate and not applicable when large variations in discharge occur.

\section{TIME-DRAWDOWN CURVES}

Drawdowns for all wells were computed as outlined in the preceding section. Curves of corrected drawdown versus log of time are given on figures 11 to 17 . The fact that individual points plot within a few hundredths of a foot of the average curve indicates that the corrections were rather accurate.

The shape of these curves is of particular interest, as it indicates that recharge occurred during the test. If no recharge occurred, the drawdown curve would continue on a downward slope. The curve is, in reality, a composite of a drawdown curve for a condition of pumping an aquifer which has no recharge plus a negative drawdown curve for a well recharging at an equal rate. The second curve enters with a time lag equal to the time required for the recharge effect to reach the observation well; thus the observed curve in the very early stages represents conditions of no recharge, the next portion is a transition as recharge becomes effective, and the horizontal portion represents developed recharge. In this test recharge was 


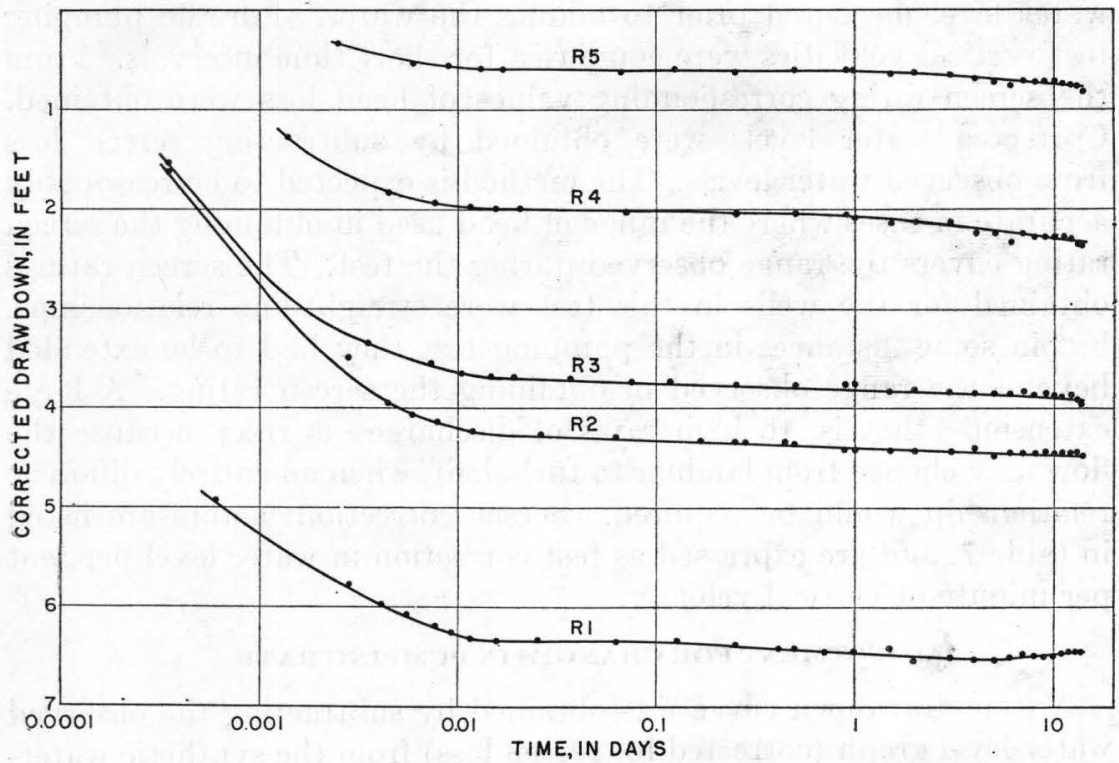

Frgure 11.-Semilog time-drawdown curves, river line of wells.

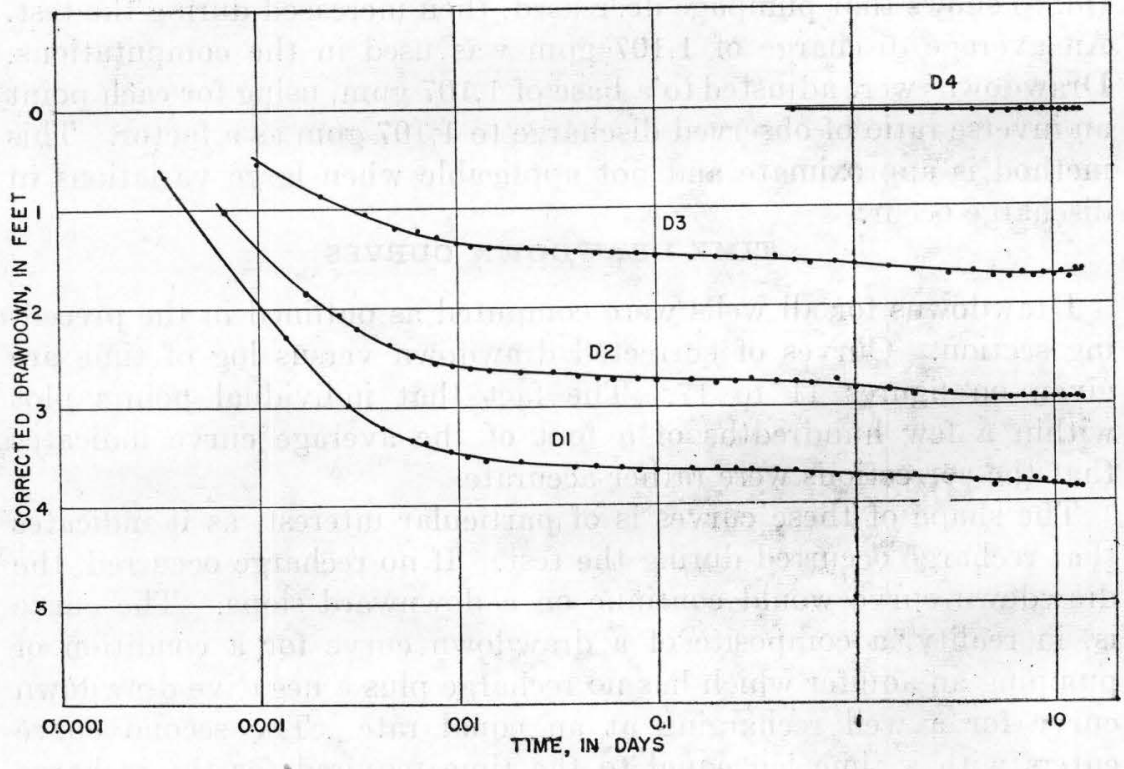

Figure 12.-Semilog time-drawdown curves, downstream line of wells.

observed within a very few minutes and was fairly well stabilized in the vicinity of the pumped well after 15 minutes. The slight downward trend of the later part of the curves indicates that the cone was 
still developing on the landward side or that the effect of the presence of the valley wall (3,500 feet distant) was being reflected to a small extent. Figure 18 illustrates theoretical curves for a condition of no recharge and for one in which recharge occurs. This curve was drawn for assumed conditions approximating those of the test area. Also shown is a comparison of observed data for well R3. Note that the shape of the curve for R3 agrees with that for the condition of recharge.

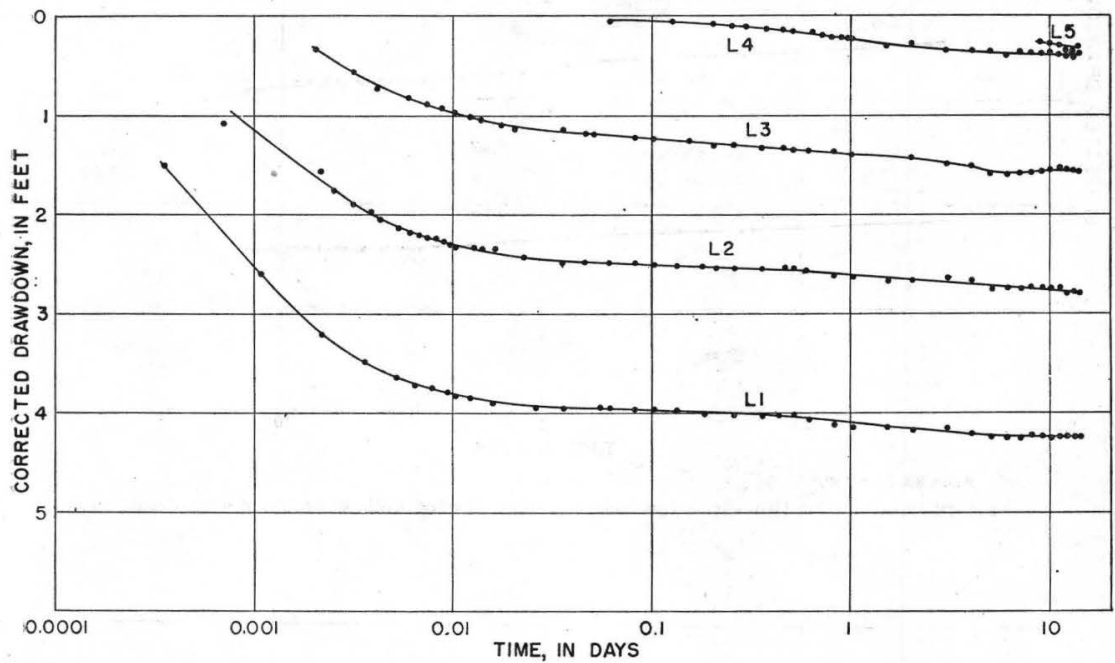

FIGURE 13.-Semilog time-d̈rawdown curves, landward line of wells.

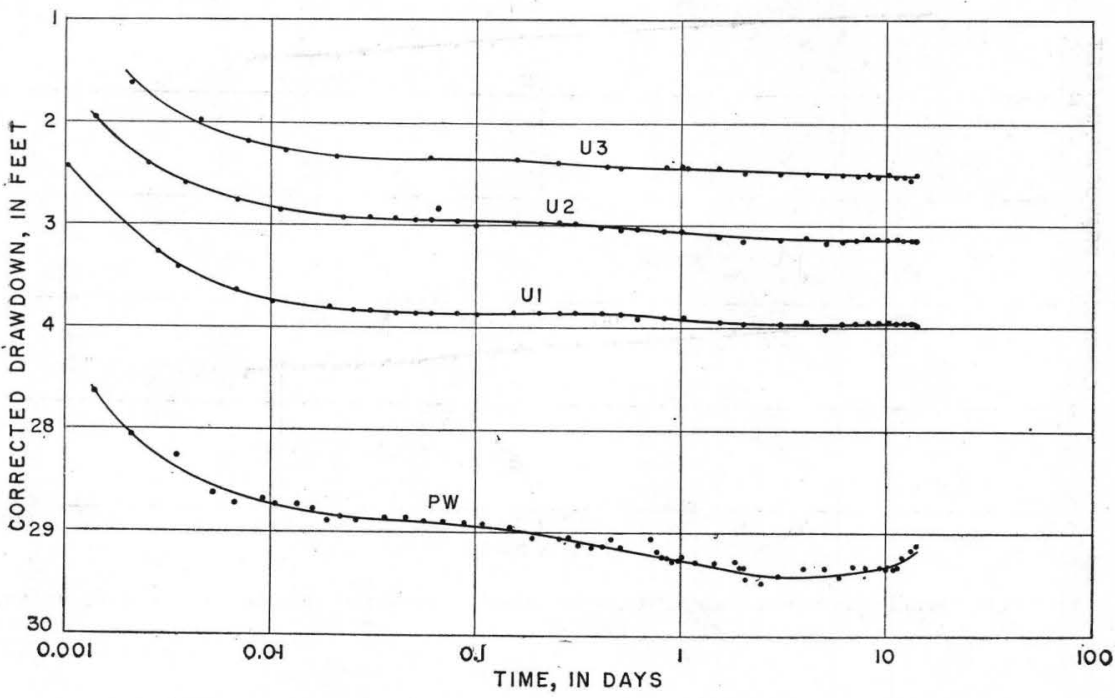

FIGURE 14.-Semilog time-drawdown curves, upstream line of wells and pumped well. 


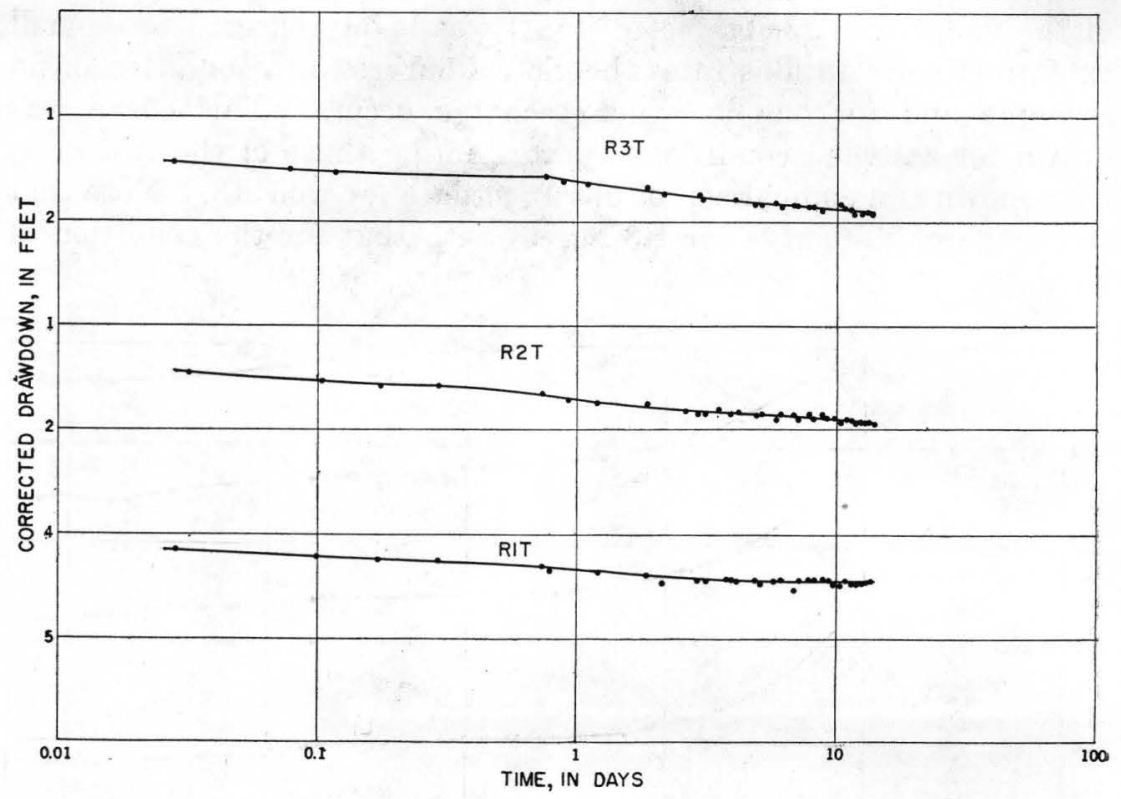

Figure 15.-Semilog time-drawdown curves, river line of wells screened at top of aquifer.

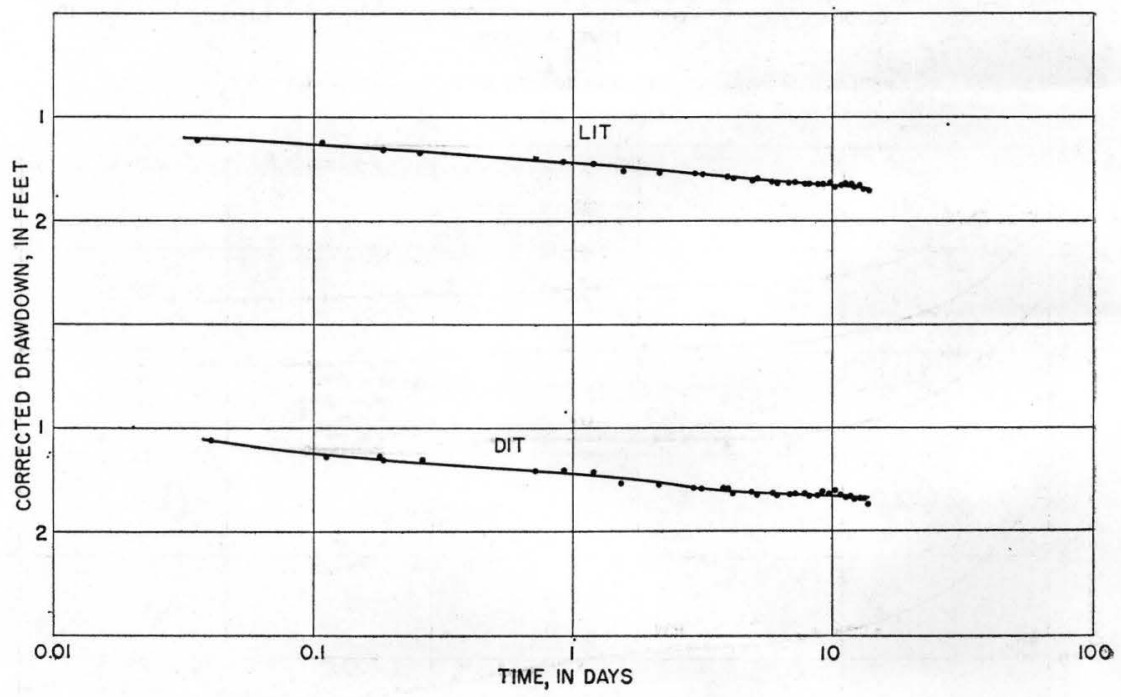

Figure 16.-Semilog time-drawdown curves, downstream and landward wells screened at top of aquifer. 


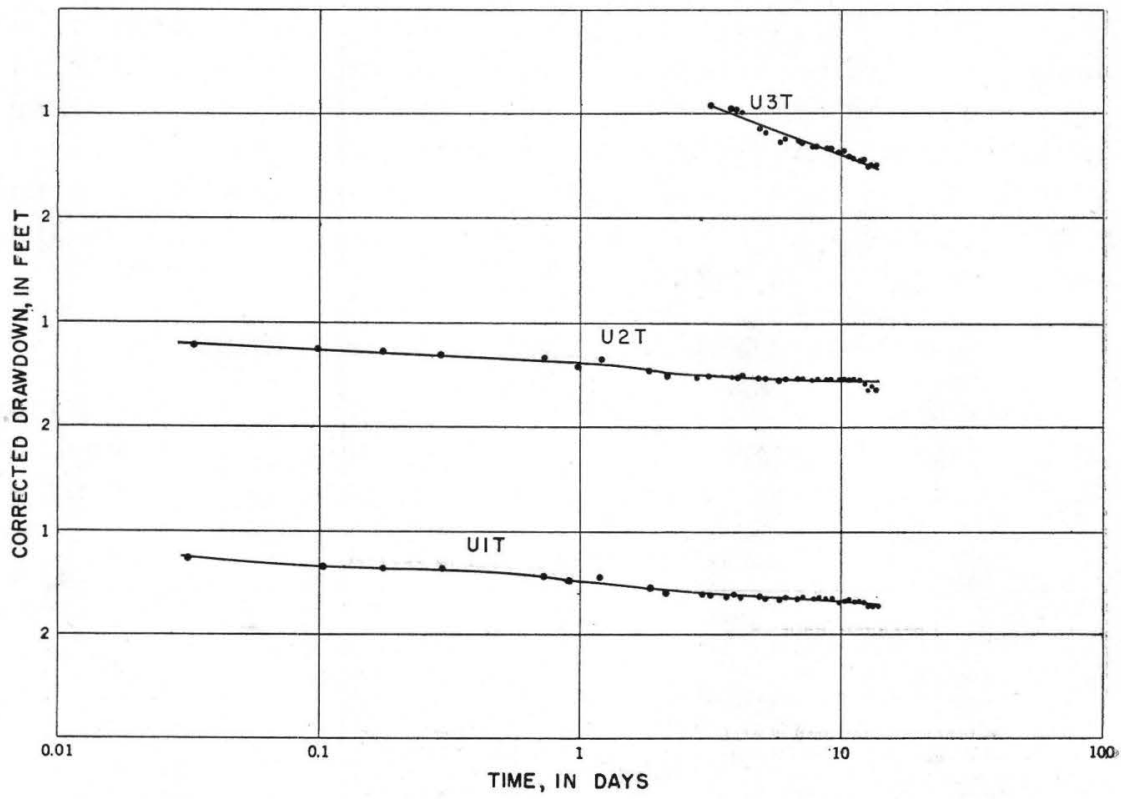

FIGURE 17.-Semilog time-drawdown curves, upstream line of wells screened at top of aquifer.

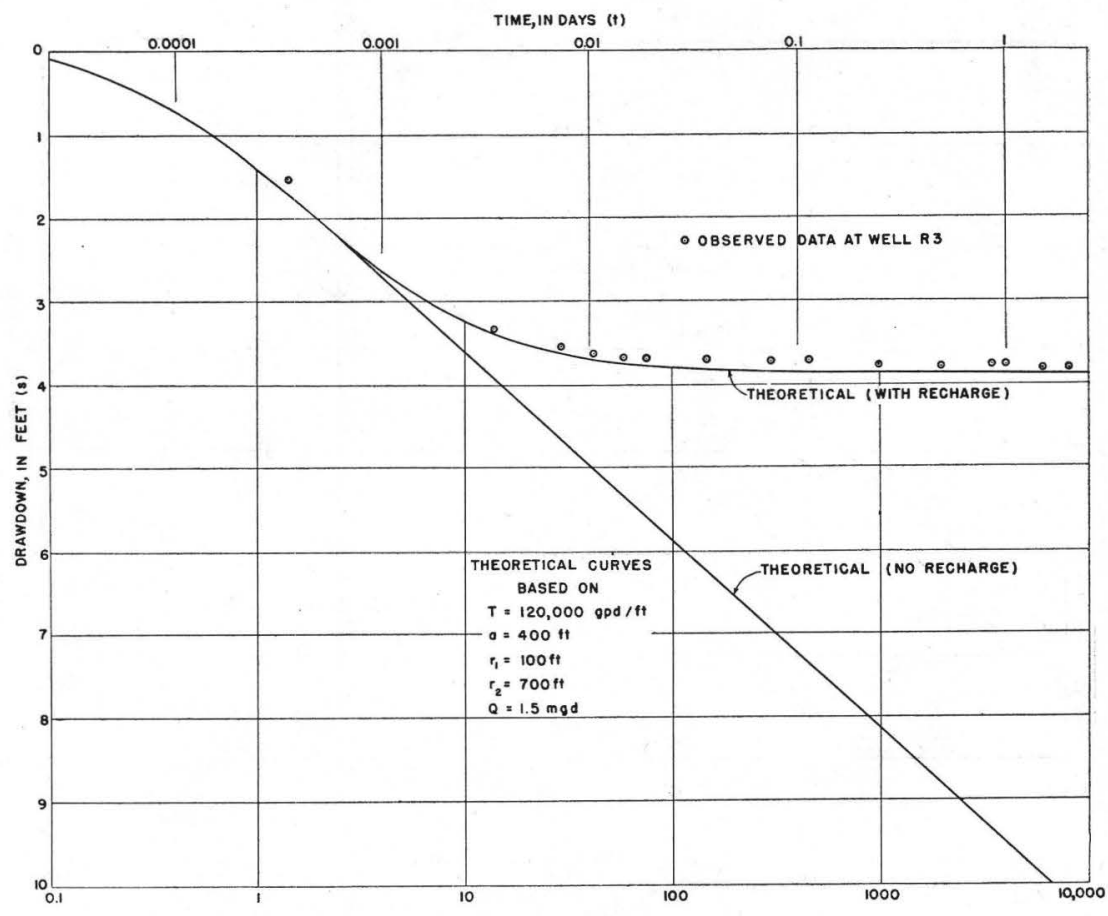

RATIO OF TIME TO STORAGE COEFFICIENT T/S

FIGURE 18.-Graph showing comparison of observed and theoretical drawdowns in an artesian aquiferaffected by recharge from river. 
Computation of transmissibility and storage coefficient can be made from the time-drawdown curve if the slope of the portion of the curve representing conditions prior to the recharge effect can be established. In the present test the recharge effect occurred in such a short time that the portion of the curve for a condition of no recharge did not have time to reach a straight line prior to the entrance of the recharge effect.

\section{PROFILES AND DISTANCE TO LINE SOURCE}

Profiles of the piezometric surface are plotted on figure 19 for a time 10 days after pumping began. In the lower part of the illustration are shown theoretical profiles for a condition in which recharge

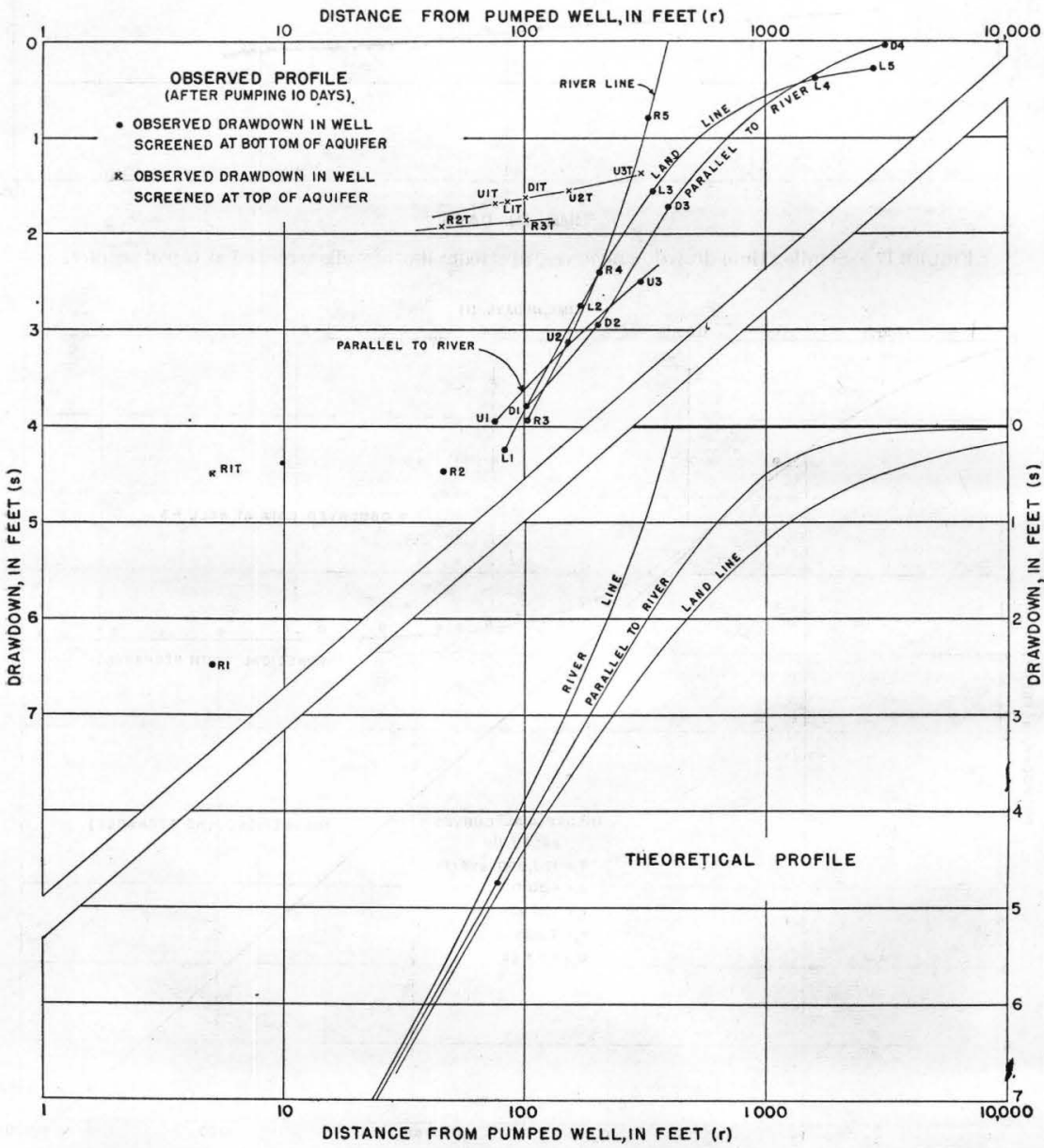

FIGURE 19.-Graph showing comparison of observed and theoretical profiles in an artesian aquifer affected by recharge from river. 
occurs. The observed profiles agree in shape with the theoretical and indicate that recharge occurred. If recharge did not occur, the data should plot on a single curve or on curves having similar shapes for cases of different transmissibilities.

The downstream profile (parallel to the river) and the riverward profile agree very closely with the theory. The upstream profile has a slope less steep than expected. This may result from differences in transmissibility or may indicate that the foundation of the Louisville Water Company Pumping Plant forms a partial barrier to flow from the upstream part of the aquifer. The profile for the landward line shows less drawdown than expected; this is accounted for by differences in transmissibility and by the fact that the cone on the landward side was still expanding; that is, a part of the flow was being contributed from storage.

The observed riverward profile bends upward and, when extended to zero drawdown, yields a solution for the distance to the line source of about 400 feet.

Computations of the distance to the line source were made using equation (3) from page 120 of this report. These determinations were made for various pairs of wells and for pumping periods of 1 day, 10 days, and 100 days (drawdowns for 100 days were obtained by extending the semilog time-drawdown curves). Computed values of the distance to the line source were quite variable. It was fornd that the values became progressively larger as larger time intervals were used. This is to be expected because, as recharge continues to develop, a larger part of the flow comes from the riverward side and a smaller part comes from storage on the landward side.

A trial computation of apparent transmissibility based on the drawdown at each well was made by means of equation (7). It was found that there was considerable variation in transmissibility, the lowest values being in the thin section of aquifer between R5 and R3 and the highest values being on the landward side. As we are primarily interested in development of flow from the river, determination of the hydrologic factors should be based on the data for wells in the thin section.

The value of the distance to the line source computed from equation (3), as determined from wells R3, R4, and R5, are: for 1 day, 380 feet; for 10 days, 400 feet. This latter value is in agreement with the profile extension.

\section{TRANSMISEIBILITY}

A large difference in drawdown was noted between wells screened at the top and those screened at the bottom (fig. 19). Assuming a homogeneous aquifer, corrections were computed for partial pene- 


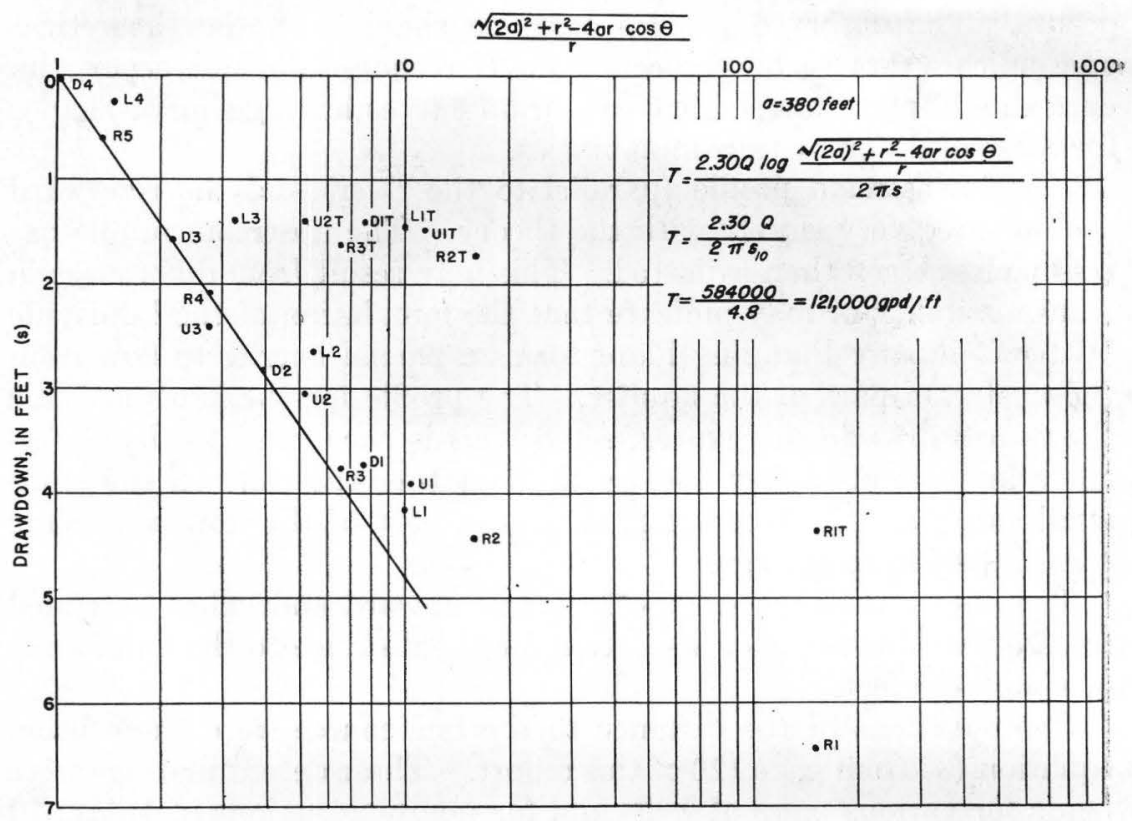

FiguRE 20.-Graphical determination of transmissibility after 1 day of pumping from an artesian aquiferaffected by recharge from river.

tration. It soon became apparent that the data could not be corrected to a single curve because of stratification of the aquifer. That vertical permeability is considerably lower than horizontal permeability is shown by comparison of the semilog time-drawdown curves: for top and bottom wells at various locations (figs. 11-17). The curve for each top well declines slowly for about 4 days before paralleling the curve for the corresponding bottom well. In making computations for transmissibility, the lower gravel bed was considered as a separate aquifer; the sand bed above, having a considerably smaller permeability, was neglected.

Figure 20 shows a plotting of corrected drawdown for all wells: for 1 day

against

$$
\log \frac{\sqrt{(2 a)^{2}+r^{2}-4 a r \cos \theta}}{r}
$$

using the distance to the line source as 380 feet. The curve was drawn giving extra weight to the data for riverward wells. Using: equation (11), the transmissibility was determined as $121,000 \mathrm{gpd} / \mathrm{ft}$. at a temperature of $59^{\circ} \mathrm{F}$. This is a minimum or "safe" value for design purposes. An average value obtained by drawing a curve averaging the data from all bottom-screened wells results in a figure of transmissibility of about $150,000 \mathrm{gpd} / \mathrm{ft}$. 
A second determination was made (fig. 21) using the data obtained after 10 days of pumping and the corresponding distance to the line source of 400 feet. This determination, $121,000 \mathrm{gpd} / \mathrm{ft}$ is the same as that obtained from data for 1 day, although such exact agreement is quite accidental; the agreement would be considered close even if there had been a difference of several percent.

\section{STORAGE COEFFICIENT}

The only method available for determining storage coefficient is to study the data obtained during the early part of the test. Drawdown data for all wells screened at the bottom were plotted against $t / r^{2}$ (fig. 22). If the transmissibility had been uniform, these curves would have begun and stayed on a common curve prior to the entrance of the effect of recharge, then would have deviated on separate transition curves approaching the horizontal. Cooper and Jacob (1946, p. 527) give the equation for drawdown in an artesian aquifer unaffected by recharge

$$
s=-\frac{2.30 Q}{4 \pi T}\left(\log \frac{r^{2}}{t}-\log \frac{2.25 T}{S}\right) .
$$

From this equation, the slope of a straight line on the semilog plot. satisfying the conditions $Q=1,107 \mathrm{gpm}$ and $T=121,000 \mathrm{gpd} / \mathrm{ft}$ is

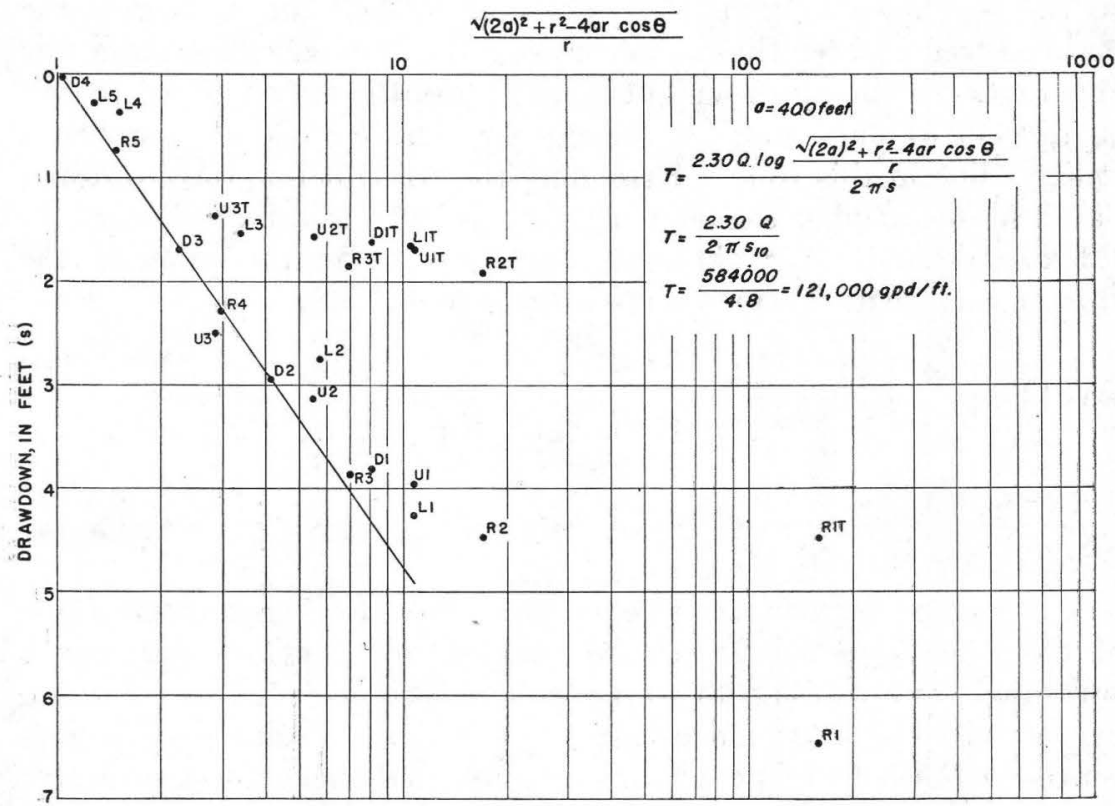

FIGURE 21.-Graphical determination of transmissibility after 10 days of pumping from an artesian aquifer affected by recharge from river. 


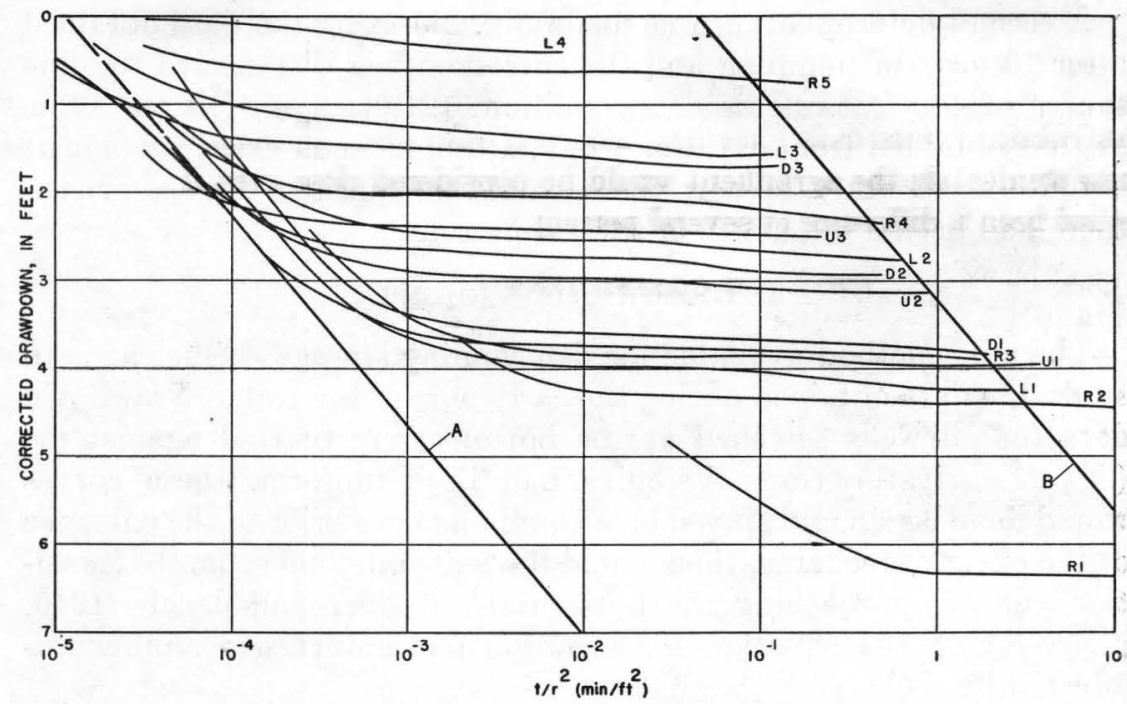

FIGURE 22.-Composite of semilog time-drawdown curves.

computed as 2.4 feet per log cycle. It should be noted that this equation is not applicable for very small values of time nor for data from wells a large distance from the pumped well. A straight line ( $A$ in fig. 22) having a slope of 2.4 feet per log cycle has been drawn on the semilog plot, giving extra weight to data for wells near the pumped well and for the period prior to the time when recharge was apparent. At the upper end a curved segment has been added (based on theory) to show that insufficient time had elapsed to establish a straight line in this zone. Extending the straight line to zero drawdown (dashed upper segment of $A$ in fig. 22), a value for $\left(t / r^{2}\right)_{0}$ of $1.2 \times 10^{-5} \mathrm{~min} . / \mathrm{ft}^{2}{ }^{2}$ is obtained. Substituting in the equation for storage coefficient (Cooper and Jacob, 1946, p. 529),

we obtain

$$
S=2.25 T\left(t / r^{2}\right)_{0},
$$

$$
S=\frac{2.25 \times 121,000 \times 1.2 \times 10^{-5}}{7.5 \times 1,440}=0.0003 .
$$

The magnitude of this figure confirms the assumption that artesian conditions existed during the test.

If it is assumed that recharge did not occur, the change in the slope of the drawdown curves toward the horizontal could represent a transition from artesian to water-table conditions. If this condition existed, the curves would approach the horizontal and, if pumping: continued for a long enough time, would then curve downward at a slope consistent with the transmissibility. To prove that this condition did not occur, a computation of apparent specific yield was made 
for the conditions recorded at the end of the test. " $A$ straight line having a slope of 2.4 feet per log cycle ( $B$ in fig. 22) was drawn on the basis of the end points of the drawdown curves, giving most weight to wells near the pumped well. From the intercept of this line with zero drawdown $\left(t / r^{2}\right)_{0}=0.045 \mathrm{~min}$./ft. ${ }^{2}$ and the apparent specific yield is computed to be 1.13. Because the specific yield cannot exceed unity, this computation proves that recharge was occurring and that pumping was continued long enough to prevent the drawing of false conclusions from the shapes of the drawdown curves.

\section{SCREEN LOSS AND EFFECTIVE RADIUS OF WELL}

In order to evaluate the screen loss and effective radius of the 12-inch pumped well, a multiple-step drawdown test (Jacob, 1947, p. 1047) was made on October 21, 1946, prior to the long test. The well was pumped for approximately 1 hour at each of five rates of discharge. Drawdown measurements (corrected for barometric and river effects) were plotted against the log of time and curves were fitted to the data. The curves were extended so that drawdown figures could be determined for 1-hour and 2-hour periods. Table 8 summarizes the data needed for analysis. Figures in column 2 are the well discharges corresponding to the step numbers given in column 1 ; columns 3 and 4 show the drawdowns obtained from the semilog time-drawdown plottings for 1-hour and 2-hour periods; column 5 shows the change in drawdown resulting from each change in pumping rate; column 6 gives the computed drawdown for each rate of pumping for a time of 1 hour, assuming that the well had been allowed to recover between steps; column 7 gives values of specific drawdown $s_{w} / Q$.

TABLE 8.-Summary of data from multiple-step drawdown test

\begin{tabular}{|c|c|c|c|c|c|c|}
\hline Step & $\begin{array}{c}Q \\
(\mathrm{cfs})\end{array}$ & $\begin{array}{l}\text { Draw- } \\
\text { down, } \\
1 \text { hour } \\
\text { (feet) }\end{array}$ & $\begin{array}{c}\text { Draw- } \\
\text { down, } \\
2 \text { hours } \\
\text { (feet) }\end{array}$ & $\begin{array}{l}\Delta s, \\
\text { 1hour } \\
\text { (feet) }\end{array}$ & $\begin{array}{c}s_{w}, \\
1 \text { hour } \\
\text { (feet) }\end{array}$ & $\begin{array}{c}\frac{s_{w}}{Q} \\
\left.\text { (sec./ft. }{ }^{2}\right)\end{array}$ \\
\hline 1 & 2 & 3 & 4 & 5 & 6 & 7 \\
\hline $4 \mathrm{~A}$ & $\begin{array}{l}0 \\
.819 \\
1.150 \\
1.587 \\
1.967 \\
1.961 \\
1.961 \\
2.530\end{array}$ & $\begin{array}{r}0 \\
8.07 \\
11.84 \\
17.35 \\
22.68 \\
22.04 \\
21.68 \\
29.81\end{array}$ & $\begin{array}{r}0 \\
8.08 \\
11.85 \\
17.36 \\
22.69 \\
22.05 \\
21.69\end{array}$ & $\begin{array}{l}0 \\
8.07 \\
3.76 \\
5.50 \\
5.32 \\
4.68 \\
4.32 \\
8.12\end{array}$ & $\begin{array}{l}0 \\
8.07 \\
11.83 \\
17.33 \\
22.65 \\
22.01 \\
21.65 \\
29.77\end{array}$ & $\begin{array}{r}9.85 \\
10.29 \\
10.92 \\
11.55 \\
11.21 \\
11.04 \\
11.78\end{array}$ \\
\hline
\end{tabular}

During step 4 the drawdown measurements were unstable. On the time-drawdown plot, three distinct curves were defined. Apparently there was a shifting of sand outside the well, resulting in additional 
development of the well and an increase in transmissibility, or a change in the type of flow near the well.

By assuming that the flow in the aquifer is laminar and that the flow in the screen area is turbulent, Jacob (1947, p. 1048) gives the equation

$$
s_{w}=B Q+C Q^{2},
$$

in which $s_{w}$ is drawdown in the well, $Q$ is the well discharge, $B$ is a constant for the aquifer and $C$ is a constant for well loss.

If this equation is put in the form

$$
\log \left(\frac{s_{w}}{Q}-B\right)=\log C+\log Q,
$$

a solution for $B$ and $C$ can be obtained which gives weight to all data and at the same time allows for experimental error. If $\left(s_{w} / Q-B\right)$ is plotted against $Q$ on logarithmic cross-section paper, a straight line having a slope of $45^{\circ}$ should be defined; further, for the value of $Q=$ unity, $C$ can be determined on the $\left(s_{w} / Q-B\right)$ scale.

Values were assumed for $B$ and a logarithmic plotting was made of $\left(s_{w} / Q-B\right)$ versus $Q$. It was found that a value of $B=8.5 \mathrm{sec} . / \mathrm{ft} .{ }^{2}$ came closest to defining a $45^{\circ}$ line (fig. 23). From the curve based on steps 4 and 5 the value of $C$ is $1.3 \mathrm{sec}^{2} / \mathrm{ft}^{5}$ (picked from intercept, $Q=1$ ).

The constants were checked by the data for 1 hour for the long test, and good agreement was found. From the equation

$$
\begin{aligned}
& s_{w}=B Q+C Q^{2} \\
& s_{w}=8.5(2.468)+1.3(2.468)^{2} \\
& s_{w}=28.92 \mathrm{ft} . \\
& \text { Observed value of } s_{w}=28.86 \mathrm{ft} .
\end{aligned}
$$

The constant $B$ was determined for a time of 1 hour of pumping, during a period when part of the flow was coming from storage. For the more stabilized condition of 10 days after start of pumping, $C=1.3$ sec. $^{2} / \mathrm{ft}^{5} ; s_{w}=29.35 \mathrm{ft} . ; Q=2.468 \mathrm{cfs} ;$ and $B=8.7 \mathrm{sec} . / \mathrm{ft}^{2}{ }^{2}$

If the well is pumped at capacity (water level drawn down to the top of the screen) the estimated discharge is obtained from the same equation using $s_{w}=54.1$ feet; $C=1.3 \mathrm{sec}^{2} / \mathrm{ft.}^{5} ; B=8.7 \mathrm{sec} . / \mathrm{ft} .^{2} \quad$ The result shows the well to be capable of producing $3.92 \mathrm{cfs}$ or $1,760 \mathrm{gpm}$.

The nominal radius of the screen is 0.48 foot. The effective radius of the well, as defined by Jacob, is the radius located by the intersection of the pressure-distribution curve of the aquifer, and the observed drawdown less the loss of head at the screen.

By combining equation (17) from page 124 (small-radius well, artesian conditions, with recharge, and modified for screen loss) with 


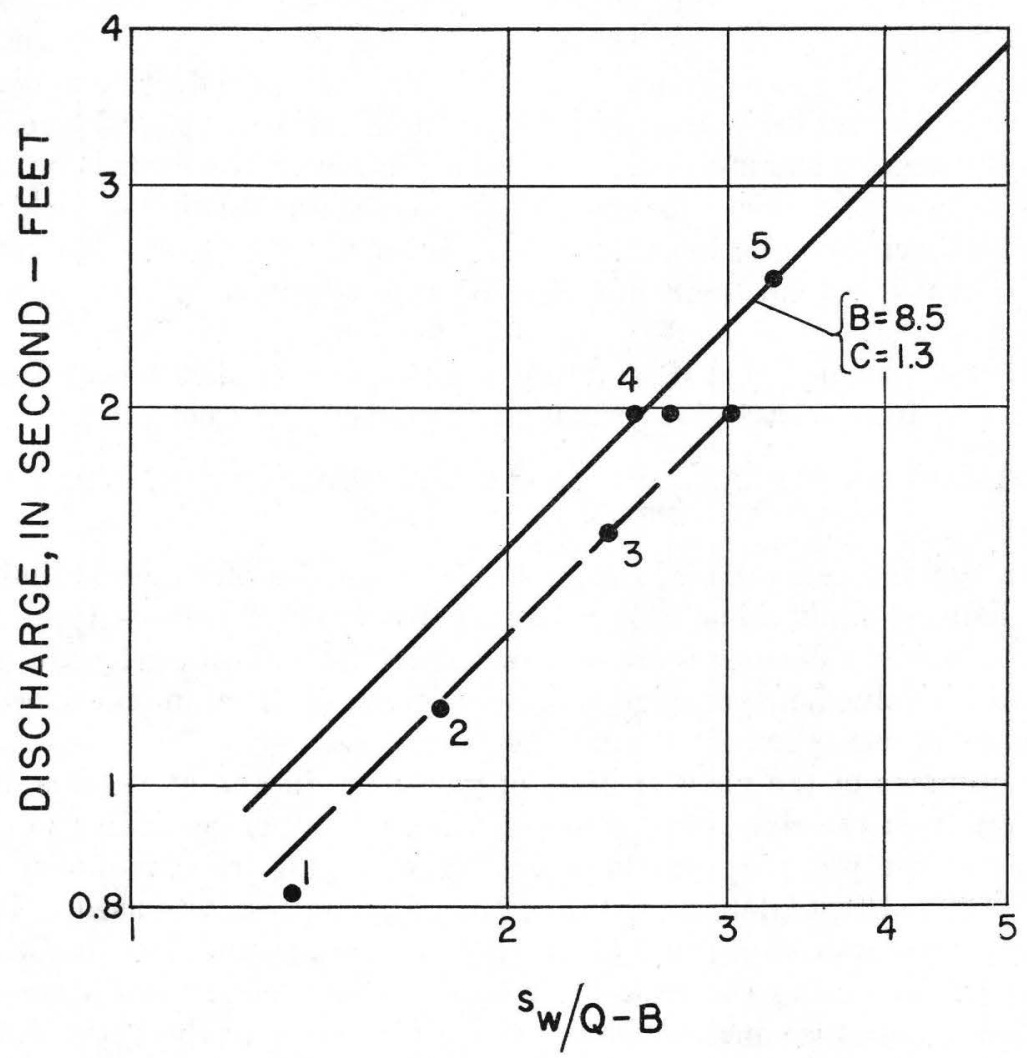

FIGURE 23.-Graphical solution of multiple-step drawdown test to determine aquifer constant $B$ and well-loss constant $C$.

the approximate equation for partial penetration by Kozeny (Muskat, 1937, p. 274) the following equation is obtained:

$$
Q=\frac{2 \pi T\left(s_{w}-C Q^{2}\right) \alpha\left[1+7\left(\frac{r_{w}}{2 \alpha m}\right)^{1 / 2} \cos \left(\frac{\pi \alpha}{2}\right)\right]}{2.30 \log \frac{2 x}{r_{w}}} .
$$

For the long test, at the end of 10 days,

$Q$, well discharge, $2.468 \mathrm{cfs}$

$T$, transmissibility (from test), $121,000 \mathrm{gpd} / \mathrm{ft}(0.187 \mathrm{cfs} / \mathrm{ft})$

$s_{w}$, drawdown in well, $29.35 \mathrm{ft}$

$C$, screen-loss constant, $1.3 \mathrm{sec}^{2} / \mathrm{ft}^{5}$

$\alpha$, percent penetration, equals screen length (30 ft) divided by average thickness of aquifer $(67 \mathrm{ft})$, or 0.45

$m$, average thickness of aquifer, $67 \mathrm{ft}$

$x$, distance to line source, $400 \mathrm{ft}$. 
Solution of this equation yields a value for the effective radius of the well of 0.64 foot. In making estimates of well production the nominal radius of various wells was used in place of the effective radius. Because the radius enters as a logarithmic ratio $\left(\log 2 x / r_{w}\right)$ and $2 x$ is very large, a small error is introduced; however, the error is on the low or safe side. On this basis a solution for the maximum yield of the test well by equation (27) gives a result of $3.72 \mathrm{cfs}$ or $1,675 \mathrm{gpm}$, somewhat less than the result of $1,760 \mathrm{gpm}$ obtained by extension of the step test.

If it is assumed that dewatering would occur, application of equation (20) from part 2 gives a maximum capacity of $1,660 \mathrm{gpm}$.

\section{ESTIMATED SUPPIIES AVAILABLE BY INDUCED INFILTRATION FROM OHIO RIVER}

In making estimates of the probable quantities of water available by induced infiltration it is necessary to consider various types of installations. Estimates are made solely on the basis of the hydrologic factors involved, no consideration being given to the economic aspects of the various types of installation.

Estimates of the yield of units of various radii and at various distances from the river were made for the section perpendicular to the river at the pumping-test location. A value for transmissibility of $121,000 \mathrm{gpd} / \mathrm{ft}$, as determined from the pumping test, was used. The line source was considered to be 350 feet from the river bank as determined during the test. For small-radius wells it was assumed that the well was constructed with 30 feet of screen at the bottom and that the pumping level would be at the top of the screen.

The value of $C$, the screen-loss constant, as computed from the step test, is $1.3 \mathrm{sec}^{2} / \mathrm{ft}^{5}$ Estimates of yield were made for small-radius wells at various distances from the river using equation (20), which allows for dewatering and screen loss, and also by use of equation (27), which accounts for partial penetration. The lower of the two values of discharge obtained was used in making estimates.

For estimates of yield of large-radius wells, equation (19) was used. This equation allows for dewatering and eccentricity, but neglects screen loss. The pumping level was assumed as 10 feet above the bedrock.

Estimates of the yield of any unit at any distance from the river at the pumping-test site are shown on figure 24 . The vertical scale in gallons per minute is for the temperature observed during the test, $59^{\circ} \mathrm{F}$. An identical vertical scale, in millions of gallons per day, is shown on the diagram. This scale is equal to the first scale multiplied by $1,000 / 1,440=0.694$. The viscosity of water at $59^{\circ} \mathrm{F}=1.14$; the second scale is, therefore, for a viscosity of $1.14 \div 0.694=1.64$, 


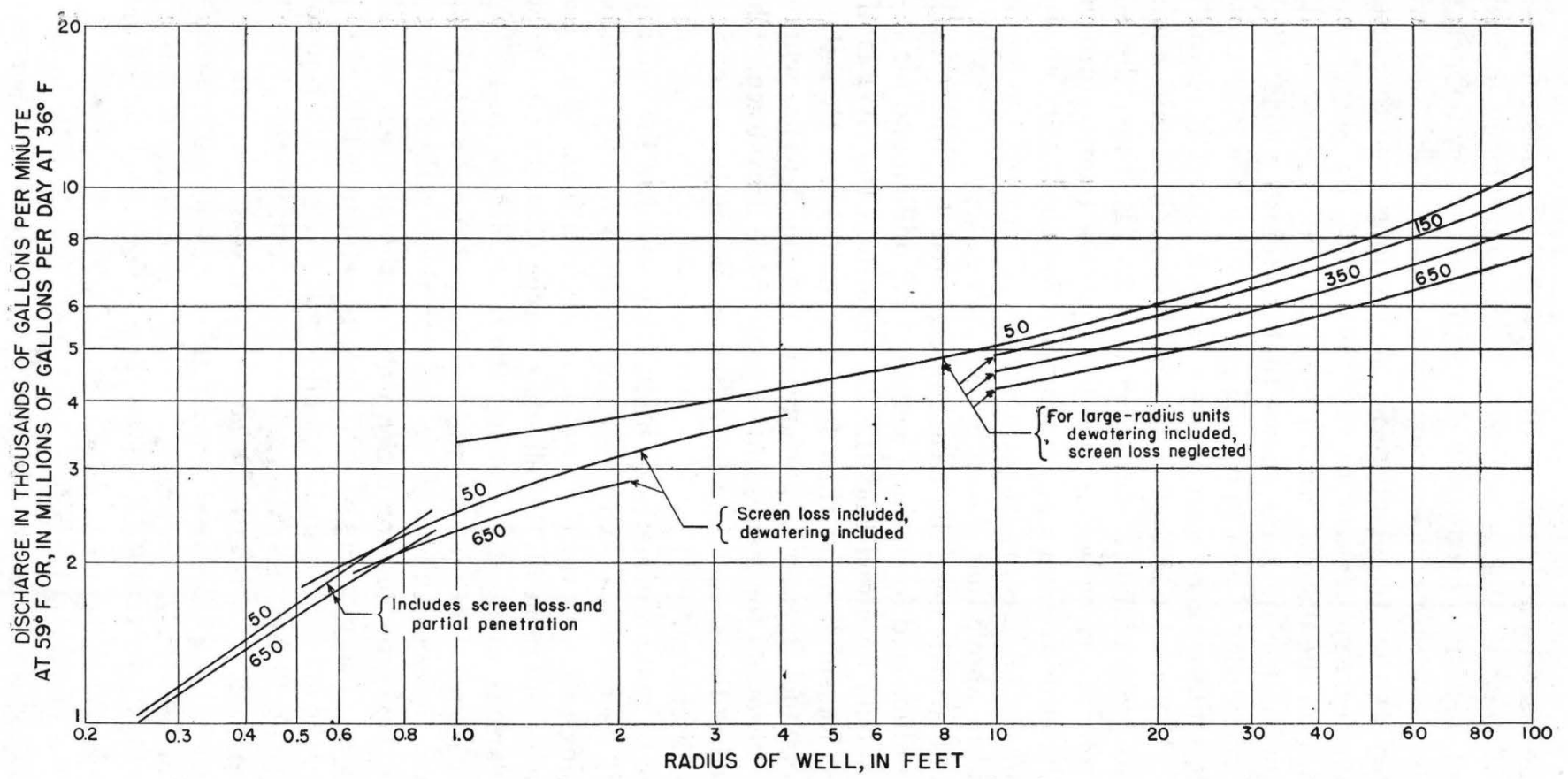

FIGURE 24.-Graph showing estimated yield of wells of different radius at various distances from the Ohio River at section 300 feet downstream from city of Louisville river intake. Parameters are distances of wells from river, in feet. 
which is the viscosity at a temperature of $36^{\circ} \mathrm{F}$. In other words, the scale in millions of gallons per day is for convenience in making estimates of maximum production during periods of low temperature. The river temperature will occasionally drop to $32^{\circ} \mathrm{F}$, but it would have to stay at that temperature for a very long time to cause the average aquifer temperature to fall below $36^{\circ} \mathrm{F}$; therefore, the yields shown on the diagram are on the conservative side.

Inspection of the diagram shows that sustained yields of about 10 million gpd at $36^{\circ} \mathrm{F}$ and 14 million gpd at $59^{\circ} \mathrm{F}$ are to be expected from single units with radii in excess of about 85 feet if placed near the river. If placed 650 feet from the river such a unit would be expected to yield about 7 million gpd at $36^{\circ} \mathrm{F}$; thus, the added distance from the river will reduce the seasonal temperature variations, so that the average aquifer temperature would stay above the value of $36^{\circ} \mathrm{F}$ used in computing the curves. Therefore, the minimum yield would be above that shown by the curves.

Small-radius wells near the river are expected to yield (at $36^{\circ} \mathrm{F}$ ) about 1.7 million gpd for 12-inch wells and 2.2 million gpd for 18-inch wells. It should be noted that the distance from the river is of less importance for small units than for large units; also that the well radius is of much greater importance in the small wells, where the screen loss accounts for a substantial part of the drawdown. Changing the well radius alters the screen loss considerably, which in turn. affects the discharge.

In order to make estimates of infiltration supplies for the area as a whole, it becomes necessary to compare the hydrologic factors of the pumping-test area with those of other locations. This can be done by a comparison of the effects of river changes on the water levels at various wells. By plotting the river factors (p. 137) of the wells in the pumping-test area against distance from the river (fig. 25), a curve was defined which can be used to relate other areas to the test area. River factors for other wells in the area are plotted on this diagram. The plotting of any point is determined by the transmissibility, the storage coefficient, and the distance to the line source. The storage coefficient is assumed to be constant. If the river factor for a given well plots below the curve defined at the test location, (the water level responds more readily to river changes) the combined effect of transmissibility and distance to the line souree is better than at the test location. If the river factor plots above the line, infiltration conditions are not as good as at the test location.

Inspection of the plotting of river factors for all wells in the area shows that conditions in general are about as good in other parts of the area as those at the test location. Water-table conditions exist at well 39-18-1. The river factor for this well is not comparable to the 


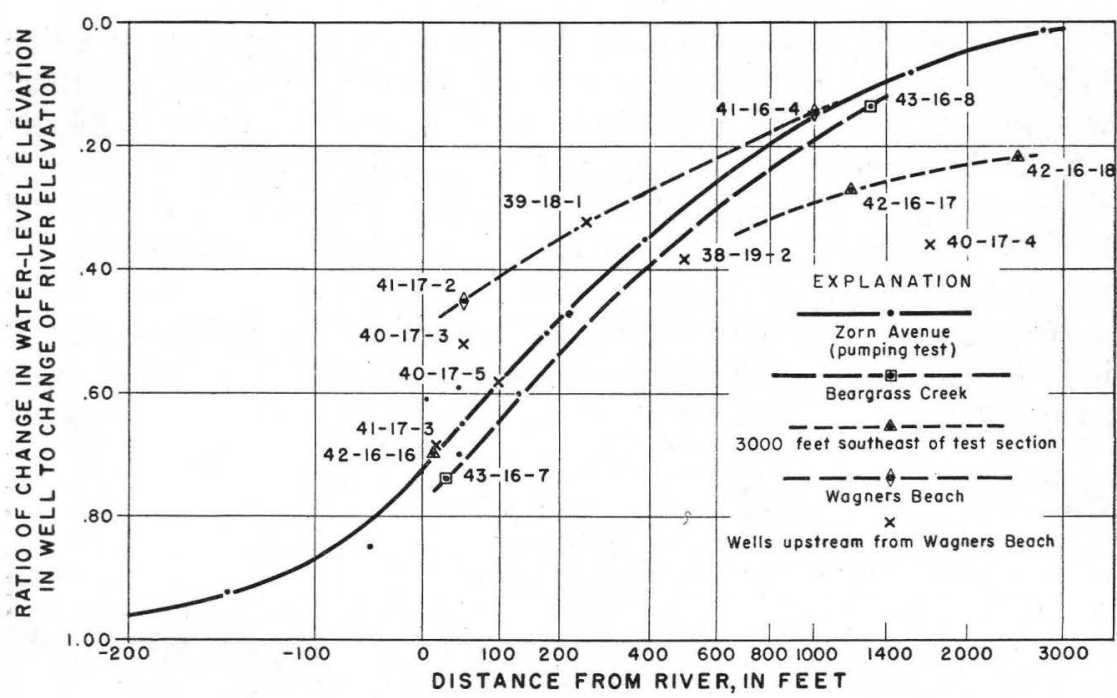

FíguRE 25.-Graph showing comparison of effects of river changes on water levels in wells in sections perpendicular to the river.

others because of the much larger storage coefficient associated with this condition; the infiltration conditions for that location are probably better than indicated by the plotting of its point on the diagram.

Estimates of the probable yield from infiltration from the entire area can be made if given types of installations are considered and if interference is taken into account.

For an array of large-radius units parallel to the line source, pumping at similar rates, and spaced on equal centers ( $d$-well spacing), an equation for the drawdown at any well is obtained by adding to the drawdown at the well the drawdown at that well caused by each other pumping well and the negative drawdowns caused by each corresponding image well.

$$
\begin{aligned}
& s=\frac{2.30 Q}{2 \pi T} {\left[\log \frac{x+\sqrt{x^{2}-r_{w}^{2}}}{r_{w}}+2 \log \frac{\sqrt{\left(2 \sqrt{x^{2}-r_{w}^{2}}\right)^{2}+d^{2}}}{d}\right.} \\
&\left.+2 \log \frac{\sqrt{\left(2 \sqrt{x^{2}-r_{w}^{2}}\right)^{2}+(2 d)^{2}}}{2 d}+\ldots+2 \log \frac{\sqrt{\left(2 \sqrt{x^{2}-r_{w}^{2}}\right)^{2}+(n d)^{2}}}{n d}\right] .
\end{aligned}
$$

As written, this equation is for the drawdown in the center unit of a line of units, and $n$ is the number of units on either side of the center unit. For safety of design it is supposed that future additional developments may be made upstream and downstream from the site. On this basis the series is extended until the last term shows interference effect small enough to be neglected. By this method the computed drawdown would apply to any unit in the line. This equa- 
tion is adaptable for computing the drawdown in any unit in a line having a definite number of units. For example, consider the third well in a line of eight wells. The first term of the series considers well 3 ; the second term, wells 2 and 4 ; the third term, wells 1 and 5 ; since wells 6,7 , and 8 have no counterpart at the other end of the line, the fourth, fifth, and sixth terms are halved by dropping the 2 preceding the log term.

If equation (28) is solved for $Q$ and allowance is made for dewatering, the equation for the discharge of a single unit in a line of units at spacing $d$ is

$$
\begin{aligned}
& Q=\frac{\frac{m_{1}+m_{2}}{m_{1}}}{2.30 \log \left\{\left[\frac{x+\sqrt{x^{2}-r_{w}{ }^{2}}}{r_{w}}\right]\left[1+\left(\frac{2 \sqrt{x^{2}-r_{w}{ }^{2}}}{d}\right)^{2}\right]\right.}
\end{aligned}
$$

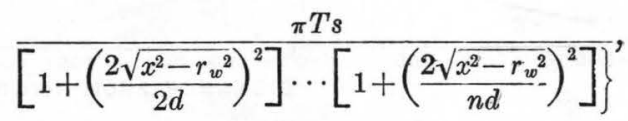

where

$$
\begin{aligned}
m_{1} & =\text { thickness of aquifer prior to pumping } \\
m_{2} & =\text { thickness of aquifer at pumped well during pumping } \\
s & =\text { drawdown in aquifer outside well } \\
x & =\text { distance from the physical center of the screen to the line source. }
\end{aligned}
$$

For small-radius wells, where $r_{w}$ is small compared to $x$, and neglecting screen loss, the equation may be expressed

$$
Q=\frac{\frac{m_{1}+m_{2}}{m_{1}} \pi T s}{2.30 \log \left\{\left[\frac{2 x}{r_{w}}\right]\left[1+\left(\frac{2 x}{d}\right)^{2}\right]\left[1+\left(\frac{2 x}{2 d}\right)^{2}\right] \ldots\left[1+\left(\frac{2 x}{n d}\right)^{2}\right]\right.} .
$$

Figure 26 for the area northeast of Louisville, shows the estimated discharge for one unit of large radius in a line of units at any distance, $x$, from the line source and at any spacing, $d$, allowing fulf development of the 6.4 mile reach along the river and any futuredevelopment upstream or downstream from the reach. As on figure 24 vertical scales are shown in gallons per minute for an average temperature of $59^{\circ} \mathrm{F}$ and in millions of gallons per day for a temperature of $36^{\circ} \mathrm{F}$. In developing the diagram the following constants: were used: $T, 120,000 \mathrm{gpd} / \mathrm{ft}$.; $m_{1}, 67 \mathrm{ft}$; $m_{2}, 10 \mathrm{ft}$; and $s, 74 \mathrm{ft}$.

As an example, suppose that a line of units of $100-\mathrm{ft}$. radius were placed 500 feet from the line source and on 1,000-ft. spacing. Enterthe horizontal scale with $x / r=500 / 100=5$; drop vertically to the parameter $d / r=1,000 / 100=10$; read the vertical scale, discharge. per unit $=6,200 \mathrm{gpm}$ at $59^{\circ} \mathrm{F}$., or 6.2 million gpd at $36^{\circ} \mathrm{F}$. If a single unit were to be installed, the estimated yield is obtained 


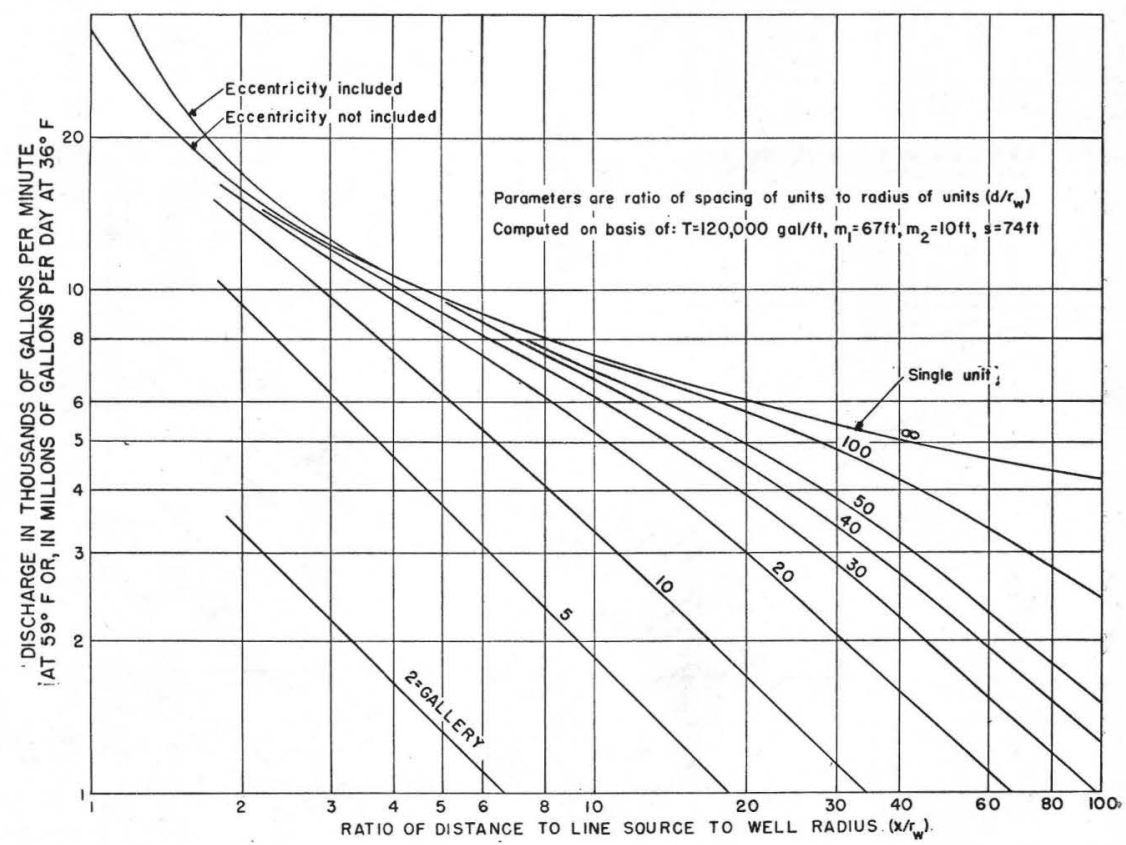

FIGURE 26.-Graph showing estimated yield of a single unit in a line of large-radius units parallel to the river, northeastern Louisville.

from the top limiting curve; for $r=100, x=500, x / r=5$, the estimated yield is $9,700 \mathrm{gpm}$ (at $59^{\circ} \mathrm{F}$ ) or 9.7 million gpd (at $36^{\circ} \mathrm{F}$ ).

In writing the equation the assumption was made that the river water enters the aquifer horizontally along a section parallel to the river, whereas the true condition is a vertical flow of water from the river downward into the aquifer over an area of river bottom, changing to horizontal flow toward the wells. Therefore, the diagram will not be applicable for values of $x / r$ less than 2 , and should be used with caution when $x / r$ lies between 3 and 2 .

A similar diagram cannot be drawn for small-radius units, as modification of equation (30) to account for screen loss and partial penetration adds additional parameters.

Figure 27 was prepared to show the estimated yield which might be expected from development of infiltration supplies along the 34,000 feet of river from Beargrass Creek to Harrods Creek. Computations. were made on the assumption that units would be on the river bank and that the distance to the line source would be about 400 feet.

For small-radius wells computations include interference, dewatering or partial penetration (smaller value used; see p. 152), and screen loss. Wells were assumed to be screened at bottom with 30 feet of 


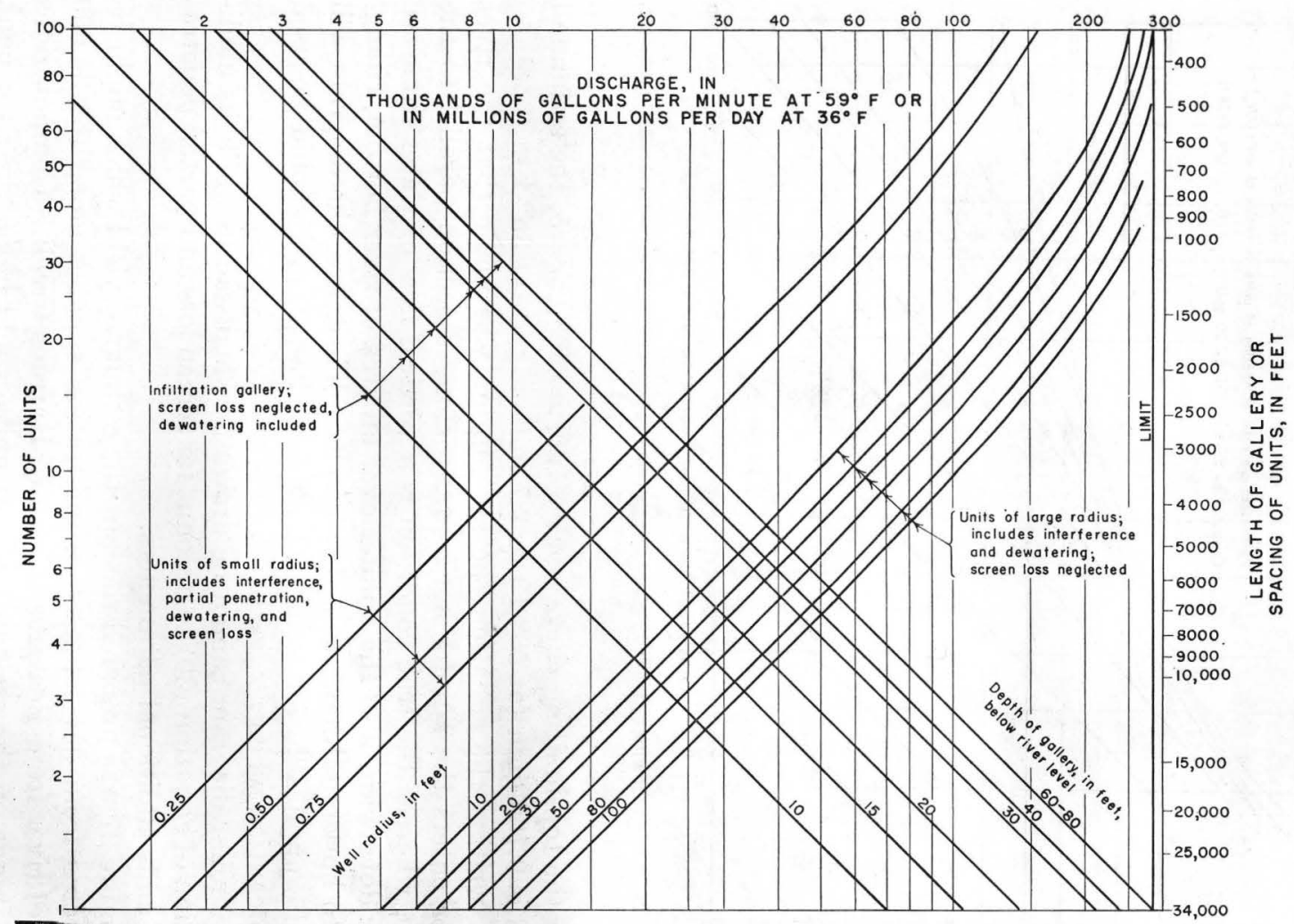

FIGURE 27.-Estimated ground-water supplies available by induced infiltration if developed by units located along bank of Ohio River in area from Beargrass Creek to Harrods Creek. 
screen. For large-radius wells, computations include interference and eccentricity.

The diagram relates three factors: well radius, number of units, and spacing, to estimated discharge. For example, what yield might be expected if 11 units of 80 -foot radius were installed? Enter diagram at 11 on left vertical scale, move right to the parameter for $r=80$ feet; read the total estimated supply on the top scale, 100 million gpd (at $36^{\circ} \mathrm{F}$ ) or $100,000 \mathrm{gpm}\left(\right.$ at $\left.59^{\circ} \mathrm{F}\right)$; also read spacing of units $(3,000 \mathrm{ft}$ ) on right scale.

Also included on this diagram is a set of parameters for infiltration galleries. The right scale is length of gallery. No allowance has been made for screen loss; dewatering has been taken into account. As an example, find the estimated yield of a gallery 10,000 feet long and 40 feet below river level; enter the diagram on the right vertical scale at 10,000 ; move left to the parameter for 40 feet; read estimated discharge, $60,000 \mathrm{gpm}$ (at $59^{\circ} \mathrm{F}$ ) or 60 million gallons per day (at $36^{\circ} \mathrm{F}$ ).

This diagram shows an estimated maximum possible development of about 280 million gpd under conditions of minimum temperature.

\section{ACCURACY OF ESTIMATES}

An appraisal of the estimates requires inspection of the factors used in their determination.

The estimates made for the area of the pumping test are considered safe. In determining the hydrologic characteristics of the aquifer at this location, care was taken to allow some safety factor; the transmissibility was determined on the basis of only the lower part of the aquifer; the minimum value of transmissibility (under the thin section at the river's edge) was used; the effect of dewatering was included in making estimates; for units of small radius, the well radius used was less than the computed effective radius of the pumped well; and partial penetration was considered.

The distance to the line source is reasonably accurate for the pumping rates used during the test. For large-radius wells located near the river, it is possible that, at high rates of pumping, the water level would be lowered to the extent that dewatering would occur under a part of the river. When such a condition prevails, the effective distance to the line source may be somewhat larger than computed, and estimates may prove to be too high; however, any error would be balanced or overcome by the safety factors mentioned in the previous paragraph.

In estimating yields of units at other locations, several sources of possible error are introduced:

The geologic conditions may be quite different. Test drilling shows that the bedrock surface is nearly flat in the section along the edge of 373763-56-5 
the river, so that no error is introduced in the factor for available head. The aquifer is nonhomogeneous. Permeabilities as determined in the laboratory differ from place to place, as well as vertically at any location. The distance to the line source may differ along the river. However, comparison of river and water-level fluctuations (fig. 25) shows that the combined effect of transmissibility and distance to the line source at different sections agree within reasonable limits with that for the test area. Errors introduced by projection of the transmissibility determined at the test area to other points will be reflected in a direct proportion. Errors introduced by the use of a constant distance to the line source are of less importance. The term $a$ appears in the equation as $1 /(\log 2 a / r)$. For small-radius wells the error is small; for large-radius wells the error will be important. If a closely spaced line of units is used the error will be directly related to the error in the distance to the line source. The thalweg of the Ohio River (shown on pl. 2) is closer to the Kentucky side in the reach downstream from Goose Island to Indian Hills Trail. In this area it is probable that the line source will be nearer the bank than at the pumping-test location. However, the valley wall in this reach is nearer the river than at the test location, so that any expected gain in discharge resulting from the position of the thalweg will be offset by the negative effect of the valley wall.

Another source of error is introduced in the screen-loss factor. Inspection of bailer samples shows that, in general, there is sufficient difference in material size to permit successful development of the expected yield from small-radius wells. However, the slot size required at any location may not agree with that used in the test. Where a smaller size slot is required, the screen loss will be larger, which in turn will reduce the capacity of the unit. This error will not affect the total yield of the field unless the average transmissibility is relatively low, but more units will be required than indicated on figure 27.

Another factor to be considered is the limiting infiltration rate of the bed of the river. It is possible that the vertical permeability of the river bed may be so low that water could not enter the aquifer as fast as it would travel horizontally to the unit. If this condition existed, dewatering would occur under part of the river, which would cause the apparent line source to move farther from the unit. Suppose that the maximum estimated yield of 280 million gpd (at $36^{\circ} \mathrm{F}$ ) were developed. Each 1-foot section along the 6.4-mile reach of the river would have to produce $8,300 \mathrm{gpd}$. If infiltration were effective over the entire width of the river (about 2,000 feet), the average infiltration rate would be $8,300 \mathrm{gpd}$ for an area of 2,000 square feet, or about $4 \mathrm{gpd}$ per square $\mathrm{ft}$ of river bottom. The rate would be greatest 
near the Kentucky bank of the river and would be considerably less toward the Indiana bank. Considering that the distance to the line source represents an average point of recharge, then half the flow would enter between the edge of the clay lip and the line source, a distance of about 250 feet. On this basis, a maximum rate of infiltration of $16.5 \mathrm{gpd} / \mathrm{ft}^{2}$ or about $720,000 \mathrm{gpd} /$ acre, would be required.

During the Second World War, the Indiana Ordnance Works, on the Indiana bank of the Ohio River several miles upstream from Louisville, developed an infiltration supply using seven collectors. As this development is in the same section of the river as the area under study, infiltration rates through the river bed should not be greatly different. R. G. Kazmann (1948a) has presented a summary of the performance of the field during the period 1941-45 and has made estimates of the safe yield of the system as installed.

Comparisons of various types can be made between the Indiana Ordnance Works development and the area under study.

Average monthly pumping rates at the ordnance plant for the lowest rate during each winter period were as follows: January 1943, 39 million gpd; February 1944, 31 million gpd; and April 1945, 42 million gpd. The minimum rate of infiltration was 31 million gpd over a length of river of 2 miles, or 15.5 million gpd per mile of river. This figure is less than the maximum possible because the pumpage was limited in several units in which pump capacity was not available to develop fully the eapacity of the unit. On this basis the area under study should be capable of producing in excess of 100 million gpd (15.5 million gpd/mile $\times 6.4$ miles $)$ if developed by units at similar spacing.

Kazmann estimated the safe yield of the field under adverse river and temperature conditions as 65.8 million gpd, or 32.9 million gpd per mile of river. This figure may be somewhat high, because dewatering was not fully taken into account in the computations. At this rate, the 6.4-mile reach under study would produce about 210 million gpd under adverse temperature and river conditions if developed similarly. Assuming units with a radius of 80 feet and an average spacing of 1,300 feet (same as at Indiana Ordnance Works), an estimate of 185 million gpd is obtained from figure 27. The area under study has two important advantages over the Indiana area: (1) the average head available is greater-the average drawdown available in the Indiana Ordnance Works units is 40 feet whereas the distance from river level to rock in the Kentucky area under study is in excess of 80 feet, of which 60 to 70 feet could be developed; (2) the valley wall in the Kentucky area averages 2,000 feet from the river as compared to 200 to 500 feet at the ordnance plant, a condition which 
would result in considerably less interference among units in the area under study.

In view of these comparisons, it appears that estimates based on figure 27 should not be unreasonable and should be on the low or safe side.

\section{SILTING OF RIVER BED}

The Obio River, except during high stages, is controlled by navigation dams throughout its entire length. During low flows when the velocities in the pool are less than half a foot per second, silt probably settles to the river bed. The possibility that silt, if deposited over a period of time, might reduce the infiltration rate from the river to the aquifer and thereby reduce the capacity of an infiltration development has caused some concern. No long-term studies have been made along the Ohio River to establish whether this effect is serious. In view of the fact that the river flow reaches high velocities (10 $\mathrm{ft} / \mathrm{sec}$ ) every spring, it is thought that the effect, if present, would be confined to short periods of low-velocity flow. Observed data at the Indiana Ordnance Works, 1941-45, and at the National Carbide Co. installation southwest of Louisville, 1945-48, show no large drop in yield which can be attributed to silting. Correlation of data now being collected should establish whether or not this variable is important.

\section{TEMPERATURE}

The temperature of the water withdrawn from a river infiltration system follows a cycle governed by the seasonal fluctuations of the river-water temperature. (Thermographs for the Peoria, Ill. well field and for the Des Moines, Iowa infiltration gallery have been published by Burdick (Meinzer, Burdick, and Morris, 1942, p. 1613) and for the Indiana Ordnance Works collector system by Kazmann (1948a, p. 411). The temperature range is less than that of the river and the highs and lows occur later than the highs and lows of the river. The temperature range of the water discharged and the time lag depend on a large number of variables: temperature of river water, distance of unit from river, spacing of units, pumping rate, volume of aquifer, porosity of aquifer, amount and temperature of ground-water flow from the land side, and the specific heat of the material in the aquifer. The water being pumped at a given time flows from the river to the unit by various paths and at rates determined by the hydraulic gradient and transmissibility; thus water entering the aquifer near the unit where gradients are steepest travels to the unit in a very short time compared to water entering the aquifer some distance upstream or downstream. In other words, the water pumped at a given time is made up of water which entered the aquifer at 
different points and at different times. This integration with respect to time causes the discharge-temperature cycle to have a narrower range than the river-temperature cycle. In addition, there is a mixing of river water at one temperature with ground water at a more nearly uniform temperature, which further reduces the range. There is an exchange of heat between the water and the sand as water at one temperature flows into sand at a different temperature. In addition, there may be movement of heat by radiation within the aquifer as well as to or from the bedrock or confining clay cover. Further complications are introduced by the changes in viscosity associated with changes in temperature; changes in viscosity alter the rate of flow, thereby retarding or accelerating all the other effects in portions of the aquifer.

At the Indiana Ordnance Works (Kazmann, 1948a, p. 407) the average pumpage during the 4-year period 1941-45 was 39.7 million g. p. d. During this period the temperature of the pumped water ranged between $46^{\circ} \mathrm{F}$ and $78^{\circ} \mathrm{F}$ while that of the river ranged between $34^{\circ} \mathrm{F}$ and $86^{\circ} \mathrm{F}$. For a similar condition of development, the area under study would be producing about 125 million g. p. d. If the installation were on the river bank, the temperature range for this condition would be less than the range of $46^{\circ}-78^{\circ} \mathrm{F}$ experienced at the Indiana Ordnance Works because of more favorable conditions: The valley wall is farther from the river, which would allow a more complete integration of the temperature variables, and a greater volume of aquifer is available for heat exchange.

At the National Carbide Co. unit southwest of Louisville pumpage averaged about 3 million g. p. d. during 1945-48, or about half of the average discharge per unit of the Indiana Ordnance Works. The aquifer at the National Carbide unit is about 45 feet thick; interference by other installations was considerably less than at the Indiana Ordnance Works; the valley wall is so far away as to be ineffective. Figure 28 shows thermographs for well discharge and river water at the National Carbide unit. Note that the discharge temperature range, $53^{\circ}-67^{\circ} \mathrm{F}$, is considerably less than at the Indiana Ordnance Works. The smaller range in temperature is to be expected because:

1. Without interference from other units a longer length of river is effective, which allows for a better integration of temperature with respect to time.

2. Lack of a barrier or valley wall makes a larger volume of aquifer available for heat exchange.

3. The discharge is made up of a smaller proportion of river water and a larger proportion of ground water. 


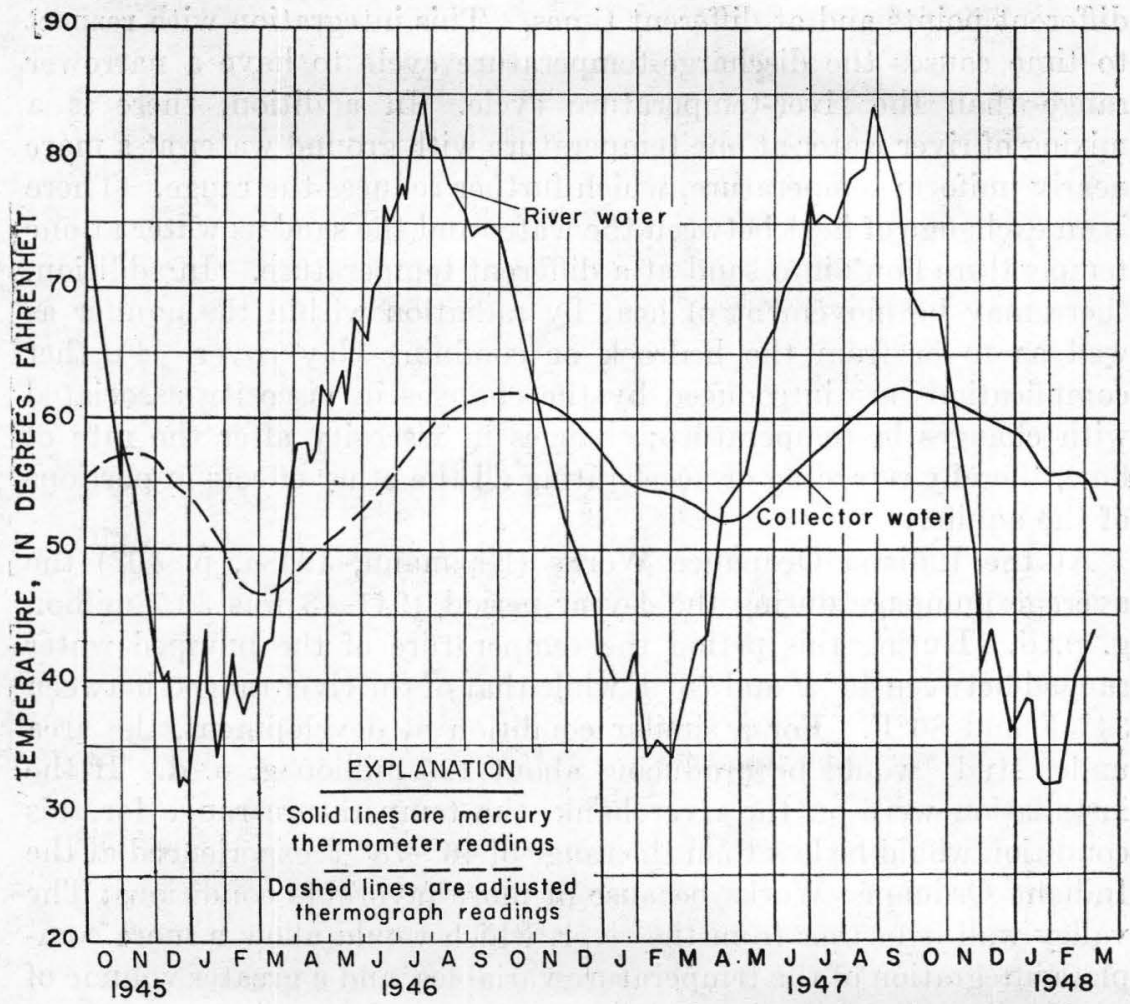

FigURE 28.-Thermographs of Ohio River water and water from collector at Bells Lane.

\section{ODORS AND TASTES}

Quantitative data are not available to establish definitely whether water from a river-infiltration development will have objectionable odors and tastes. The relatively small amount of data for existing river-infiltration installations discloses no record of objectionable odors and tastes. Jeffords (1945) in a report on infiltration supplies at Parkersburg, W. Va., states that over a 15-year period tastes and odors have not been reported in the well water. Kazmann (1948a p. 419) states that odors and tastes were apparently absent at the Indiana Ordnance Works installation, although no systematic attempt was made to detect them. These reports indicate that, if odors or tastes were present, the amounts were too small to be objectionable.

Comparison of these infiltration systems with rapid-sand filters shows two possible explanations for the conflicting results; that is, that the infiltration systems apparently remove odors and tastes, whereas the rapid-sand filter does not. 
1. the time during which the water is in contact with the sand-a few hours, at most, for the filter-is in striking contrast with the several days or more for the aquifer.

2. the integration of flow from the river to the unit with respect to time. Odors and tastes in the river vary considerably from time to time, being present in minimum amounts during seasons of medium and high flow and reaching maximum amounts during prolonged periods of low flow. This indicates that the objectionable features are associated with industrial wastes which are at highest concentration during low water, or with bacteria or plant life which develops rapidly in the slowly moving water behind the navigation dams. Water being pumped at any time is a mixture of water which left the river at different times, so that water which left the river during a period of low flow is mixed with water which entered the aquifer during a flood period. Even if the objectionable odors and tastes are not removed largely or entirely, and it appears that they may be, their effects will be reduced by this integration process.

\section{EFFECT OF DEVELOPMENT OF INFILTRATION SUPPIIES ON EXISTING WELLS}

Plate 6 shows that the ground-water flow toward the southwest occurs in the area as far upstream as Wagners Lane. Any new development upstream from Wagners Lane would have a negligible effect on existing wells in Louisville. If a unit of capacity of 10 million gpd were placed at the pumping-test site 300 feet downstream from the Louisville Water Co. river intake, about 3,000 feet southwest of Wagners Lane, water levels would be affected for several thousand feet in all directions. Theoretical draw-downs for such an installation were subtracted from the water levels of August 15, 1946. The resulting water-level elevations define a ground-water divide at a section perpendicular to the river and 4,000 feet downstream from the test location. For this condition, an estimated 250,000 gpd would be diverted from the normal southwesterly flow to the new installation. The reduction in the capacity of wells in the southwestern part of the area under study would be less than 5 percent. The annual deficit to the overpumped downtown area of Louisville would be increased by about $200,000 \mathrm{gpd}$, which would increase the rate of decline of water levels in that area by about 1 foot per year.

If a unit of capacity of 10 million gpd were placed near the river at Freys Lane, the ground-water divide would be in the vicinity of Beargrass Creek. The capacity of nearby wells would be reduced about 20 percent. Flow toward the downtown area would be reduced 
about $400,000 \mathrm{gpd}$, resulting in an increase in the rate of decline in that area of nearly $2 \mathrm{ft} / \mathrm{yr}$.

\section{SUMMARY AND CONCLUSIONS}

The glacial-outwash deposits underlying the Ohio River flood plain southeast of the river in the 3-square-mile area between Beargrass Creek and Harrods Creek (northeast of Louisville) form the best source in the Louisville area for future development of large supplies of ground water. Test drilling shows that the bedrock surface is relatively flat, lying between elevations of 335 and 340 feet above mean sea level, which is about 80 feet below the elevation of the Ohio River and the water levels in observation wells. The glacial outwash is made up of material which will be satisfactory for screening and development of wells.

The transmissibility of the aquifer has been computed at 121,000 gpd/ft at the pumping-test site 300 feet downstream from the city of Louisville pumping station. Analysis of the pumping test proves that large supplies can be developed by induced infiltration from the Ohio River. At this site the effective line of recharge is about 350 feet from the bank of the river. Comparison of the effects of changes in river level with corresponding changes in water levels in observation wells shows that conditions throughout the reach of the river under study are not greatly different from those at the test site.

Comparison of laboratory determinations of permeability shows considerable difference vertically in single wells, and, to a lesser extent, differences in transmissibility from one location to another. In planning the development of large supplies, additional pumping tests should be made in order to evaluate the hydrologic factors more closely at any location.

The maximum dependable yield which could be developed in the area under conditions of lowest river level and temperature is estimated as not less than 280 million gpd. In making this estimate all factors were given consideration except the limiting infiltration rate of the bed of the river, and all estimates were kept on the safe side. Such development would require an average infiltration rate of 4 $\mathrm{gpd} / \mathrm{ft}^{2}$ and an estimated maximum rate of about $750,000 \mathrm{gpd} /$ acre. Comparison with the developed area at the Indiana Ordnance Works shows that the area under study is better in two respects: (1) a greater head is available and (2) the negative effect of the valley wall would be less. A comparison based on the actual yield (the maximum yield was not developed) of the Indiana Ordnance Works installation shows that, if developed similarly, the area covered in the present report would produce in excess of 100 million gpd. A comparison based on Kazmann's estimate of the safe yield of the ordnance-works 
installation indieates a potential development in the area under study of 180 million gpd. It should be noted that the comparisons are based on a particular installation and spacing and are not the maximum possible.

Chemical analyses show that the ground water in the area is suitable for domestic and industrial use. The water is moderately hard, averaging about $200 \mathrm{ppm}$ higher than river water. However, if infiltration supplies were developed, the chemical content of the pumped water would represent a mixture of river water and ground water. The developed supply would carry more mineral matter than the river water but less than the ground water.

Bacteriological examination of two samples taken during the pumping test by the Kentucky State Department of Health indicated that the well water was free from sewage or other fecal pollution.

Development of large infiltration supplies in the area between Beargrass Creek and the city of Louisville pumping plant would cause interference with the flow of ground water to the downtown area of Louisville, the expected effect of development of 10 million gpd near the city of Louisville river intake and at Freys Lane being additional declines in the downtown area of Louisville of about 1 and 2 feet per year, respectively.

\section{LITERATURE CITED}

Butts, Charles, 1915, Geology and mineral resources of Jefferson County, Ky.: Ky. Geol. Survey, 4th ser., v. 3, pt. 2, 270 p.

Cooper, H. H., Jr., and Jacob, C. E., 1946, A generalized graphical method for evaluating formation constants and summarizing well-field history: Am. Geophys. Union Trans., v. 27, no. 5., p. 526-534.

Ezekial, M., 1941, Methods of correlation analysis: New York, John Wiley \& Sons, Inc.

Fishel, V. C., 1942, Discharging apparatus, in Wenzel, L. K., Methods for determining permeability of water-bearing materials, with special reference to discharging-well methods: U. S. Geol. Survey Water-Supply Paper 887, $192 \mathrm{p}$.

Jacobs, C. E., 1947, Drawdown test to determine effective radius of artesian well: Am. Soc. Civil Eng. Trans., v. 112, p. 1047-1070.

Jeffords, R. M., 1945, Ground-water conditions along the Ohio Valley at Parkersberg, W. Va. Geol. Survey, Bull. 10.

Kazmann, R. G., 1946, Notes on determining the effective discharge to a line of recharge: Am. Geophys. Union Trans., v. 27, no. 6., p. 854-859.

- $1948 \mathrm{a}$, River infiltration as a source of ground water supply: Am. Soc. Civil Eng., Trans., v. 113, p. 404-424.

- $-1948 \mathrm{~b}$, The induced infiltration of river water to wells: Am. Geophys. Union Trans., v. 29, no. 1, p. 85-92.

McAdams, W. H., 1942, Heat transmission: New York and London, McGrawHill Book Co., Inc.

Meinzer, O. E., Burdick, C. B., and Morris, S. B., 1942, Ground water-a vital national resource: Am. Water Works Assoc. Jour., v. 34, no. 11. 
Muskat, M., 1937, The flow of homogeneous fluids through porous media: New York, McGraw-Hill Book Co., Inc. Equation quoted from Kozeny, J., 1933, Wasserkraft und Wasserwirtschaft: v. 28, p. 101.

Theis, C. V., 1935, The relation between the lowering of the piezometric surface and the rate and duration of discharge of a well using ground-water storage: Am. Geophys. Union Trans., pt. 2, p. 519-524.

Wenzel, L. K., 1942, Methods for determining permeability of water-bearing materials, with special reference to discharging-well methods: U. S. Geol. Survey Water-Supply Paper 887, 192 p. 


\section{N DEX}

\begin{tabular}{|c|c|}
\hline Page & Page \\
\hline Acknowledgments_. 104 & Jeffersonville limestone.... \\
\hline 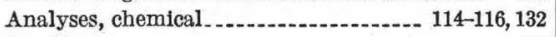 & Joints in bedrock....... 109,117 \\
\hline Aquifer_-_. 112 & \\
\hline dependable yield. & Line source... \\
\hline stratification. & $120-121,145$ \\
\hline thickness. & Line source, graphical method for determining \\
\hline Artesian conditions. 112,148 & $\begin{array}{l}\text { transmissibility } \\
\text { Louisville area, effect of pumpage on supplies }\end{array}$ \\
\hline Bedrock & of water. \\
\hline ground-water flow in $\ldots . . . . . . . .109-110,113,116$ & industrial expansion... \\
\hline surface & Louisville limestone \\
\hline Capacity, of test well & Measurements in wells... \\
\hline $110,128,133$ & \\
\hline Coefficient, of storage............ 112, 144, 147-148 & Ohio River...... \\
\hline of transmissibility & silting of bed \\
\hline Cone of pressure distribution & stage \\
\hline $\begin{array}{l}\text { Corrections, screen loss.... } \\
\text { water-level fluctuations, barometric pres- }\end{array}$ & $\begin{array}{l}\text { valley cut in bedrock. } \\
\text { pollution }\end{array}$ \\
\hline
\end{tabular}

sure changes........... 136-138

river-level changes_...-.................. 136, 137

Discharge, average during test_..-...-...-... 129, 139

Drawdown........................ 123, 146, 149, 150,155

observed and theoretical.................. 143, 144

relation to time............................. 139-143

Eccentricity of well

Equations, barometric correction factor-..-... 137

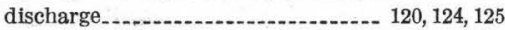
distance to line source . . .................. 120, 121 drawdown partial penetration ......................... 123 transmissibility well discharge . . .

Errors, probable.-......... 159-160

Glacial-outwash deposits......- 102, 109, 112, 126-128

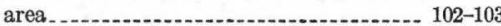
as aquifer future development. . . . water in

Ground water, discharge.................... 113 flow, bedrock flow, glacial outwash. . ........... 112-113, 133, 165 stored in aquifer......................... 112

Hardness of water........................... 116

Head, available................................. 128

Image well

Indiana Ordnance Works, use of water....... 163

Induced infiltration, theory of............. 117-125

Industries, location ....................... 102

Infiltrated water, estimates yield... 153, 154, 157-159 odor and taste.................................. 164-165

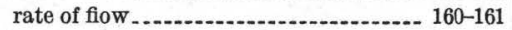

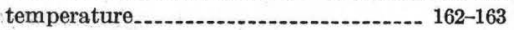
Infiltration, induced............................ 103

Interference. . . .

Investigation, purpose

Jacob, C. E., cited......................... 124, 150
Ordovician rocks.

Permeability _............... 110, 112, 118, 146, 160, 166

Piezometric surface, profles............ 112, 144-145

Pumping, effect of

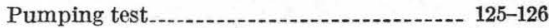

duration............. 129

Radius of wells, effective.............. 123, 150, 152

Recent alluvium . . ......................... 109, 110, 128

Recharge, natural

Report, scope

River factor . . .

Rubber Reserve Co

Sampling, geologic water

Screen loss_............. 123, 135, 138, 149, 152, 154, 160

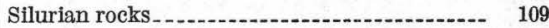

Specific yield, apparent._._._. 148-149 computation............................. 148-149 water table.................................... 112

Stuart, W. T. cited.-...- 112 Sulfate content........................... 116, 131, 133

Surface water

Temperature ................................. 118, 129-131

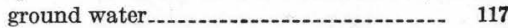
infiltrated water

Temperature distribution during infiltration

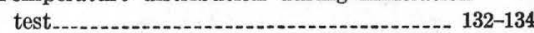

Test, multiple step........ 129, 149 graphical solution ....................... 150-151

Transmissibility ...................... 112, 122, 152, 160

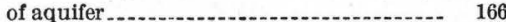
graphical method.................. 122, 146, 147

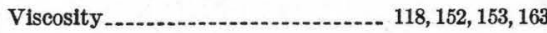

Waldron shale Water levels in wells ............ 110-111, 112, 128, 138

Well construction. ............................ 128 records

Wells, designation................................ 104 test_. . . . . . 